\title{
جدلية الحرب والسلام بين كاتت وهيجل
}

د. ميثم محمد يسر / جامعة واسط / كلية الآداب / قسم الفلسفة

- إنَ الآراء التي طرحت حول موضوع الحرب كثيرة، وفي ذلك انقسم الفلاسفة منذ القدم الى فريقين

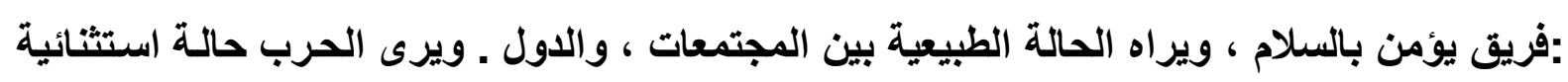

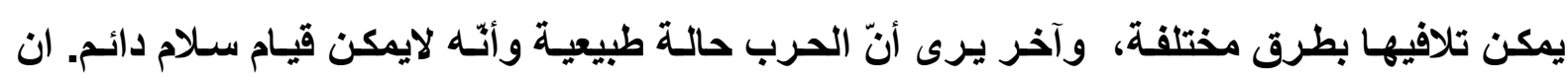

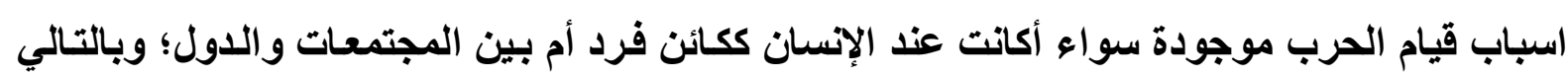

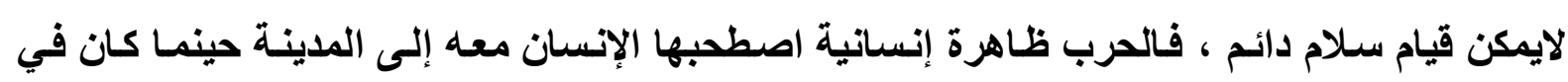

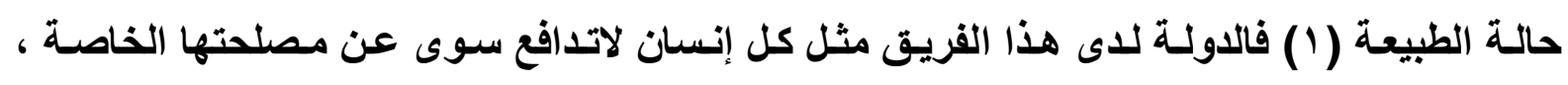

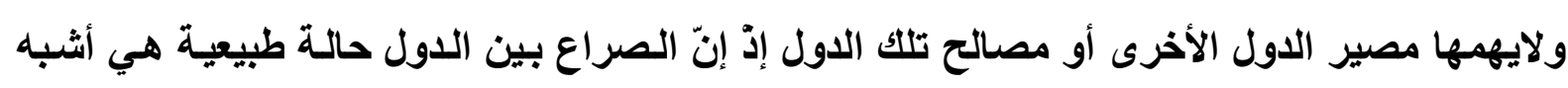

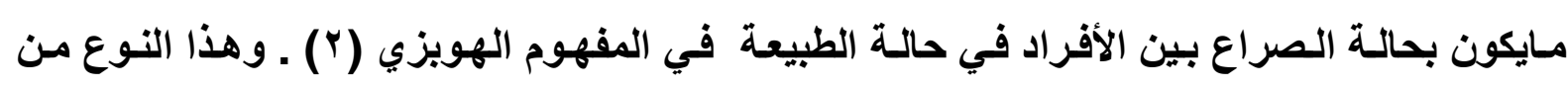

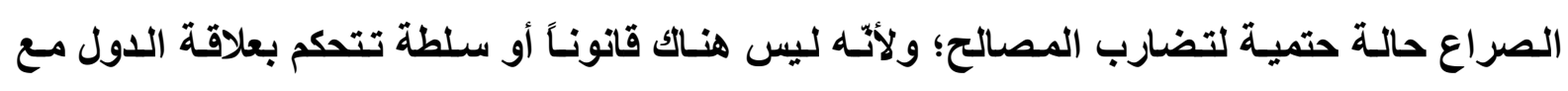

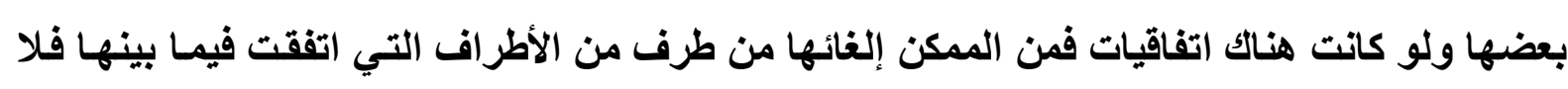

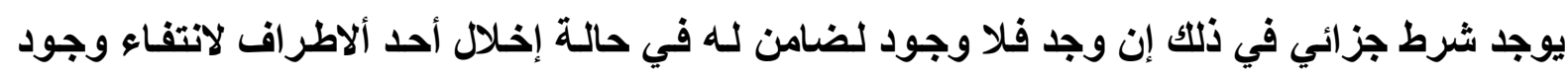

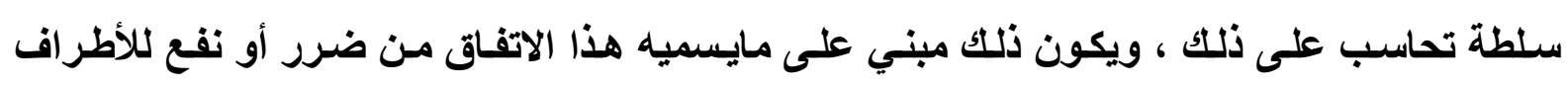

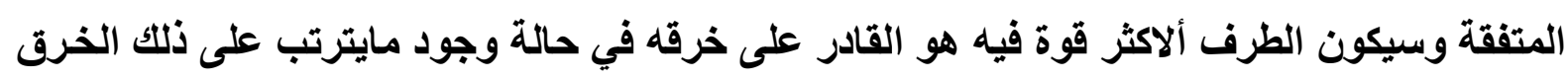

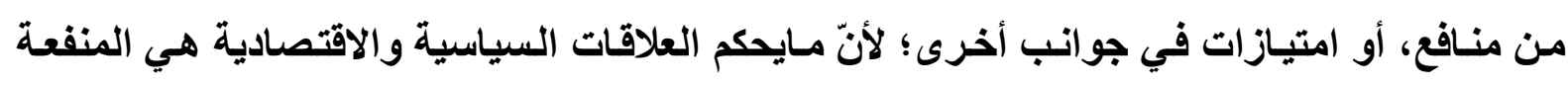

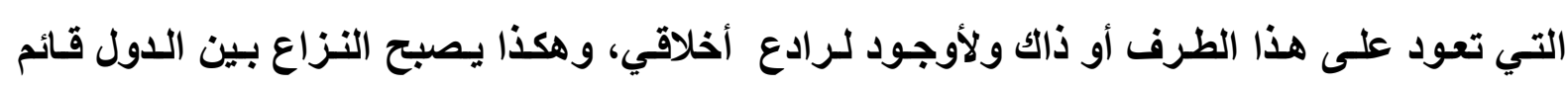

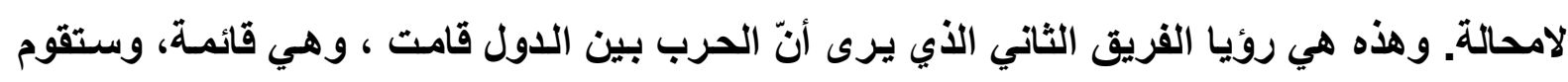

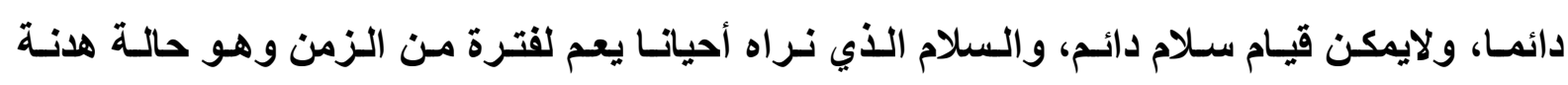

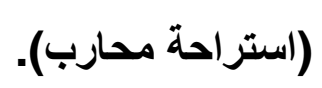

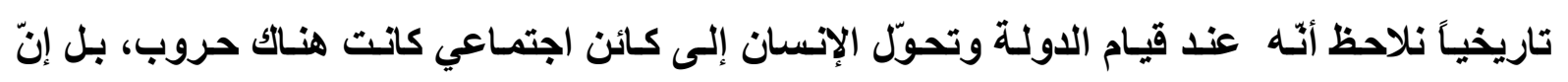

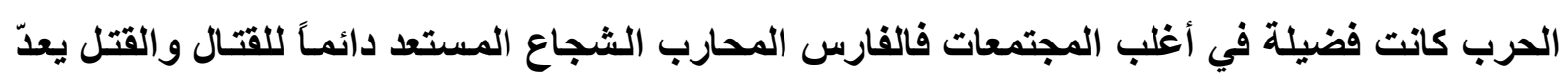

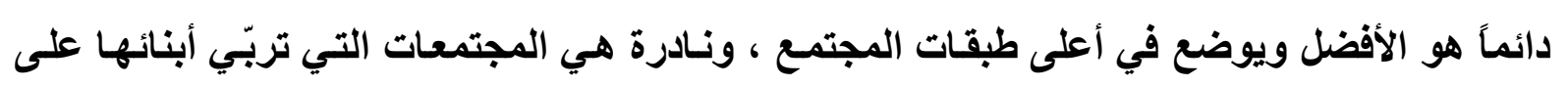

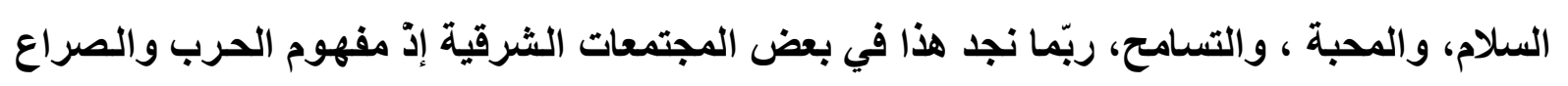

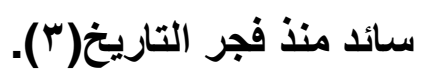
إنّ صراع الإمبراطوريات في الثرق القديم دليل على أنّ الحرب قديمة ، وليست استثنائية، وهي حالة

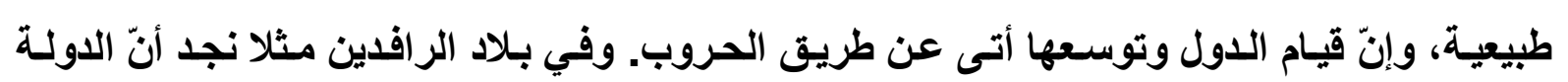


آلاشورية هي من أكثر الإمبراطوريات التي أسست عقيدتها على الحروب، فوجودهـا قائم على أسساس

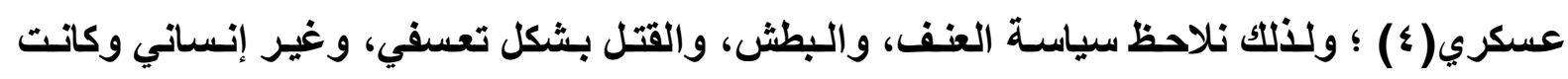

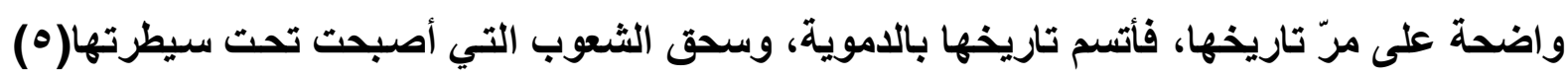

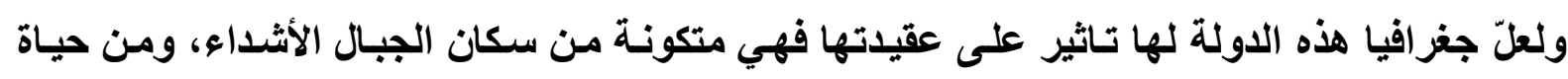

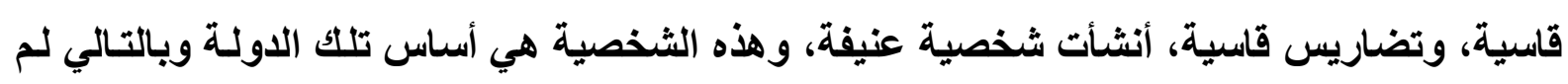

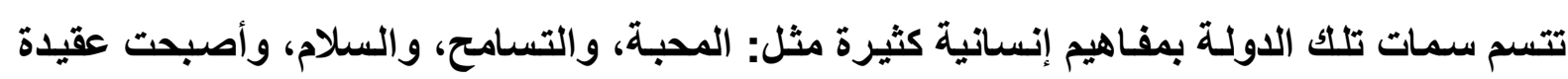

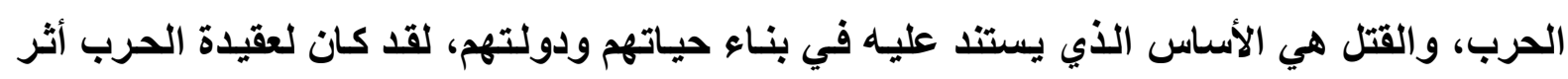

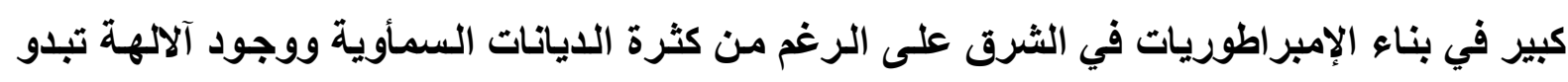

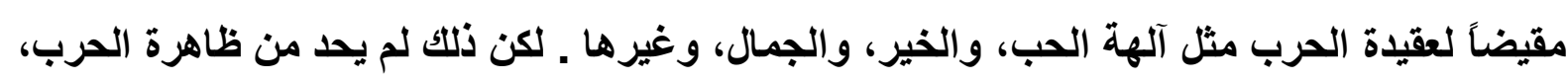

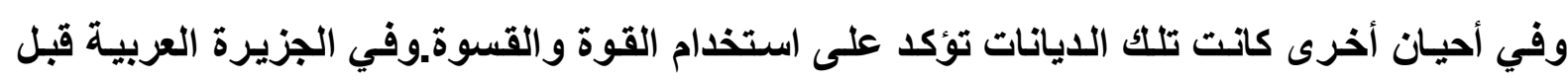

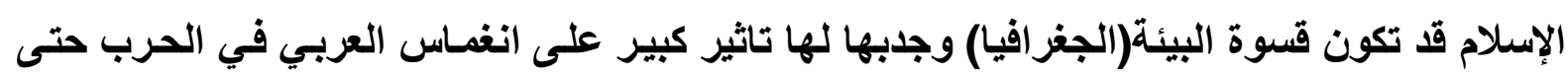

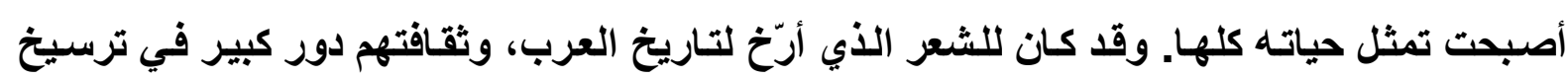

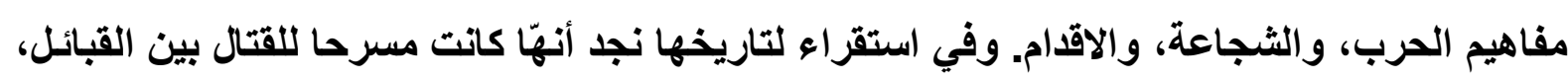
وقد أرّخ الشعر الذي هو ديوان العرب لأغلب الوقائع والحروب التي دارت بين القبائل حتى كـادت ولتهات

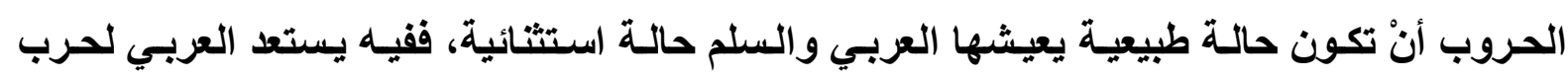

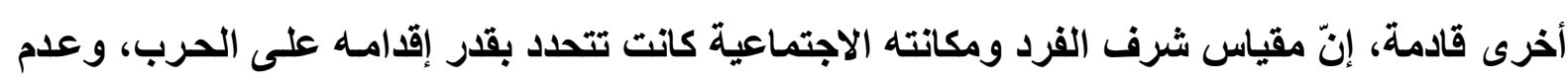
الخوف منها، وقربه على العدو، وعدم الفرار من المعركة. فالحرب وممارستها والتفكير بها، تمثل فئل

تقريبا مجمل حياة العربي أو كل تاريخه( آ).

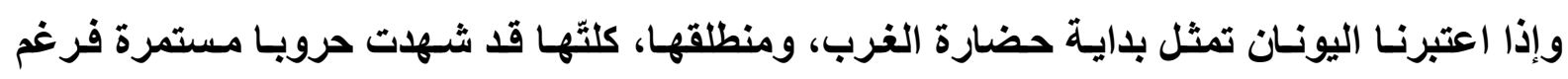

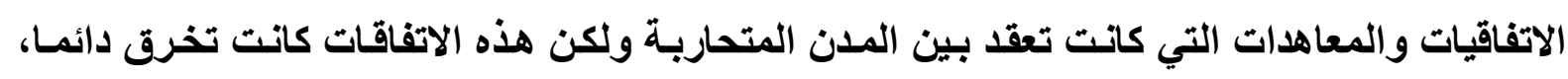

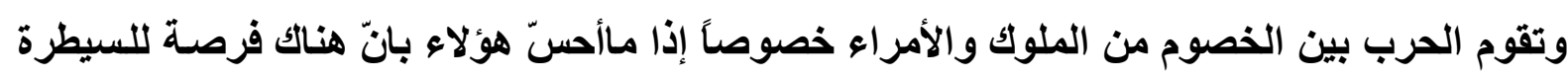

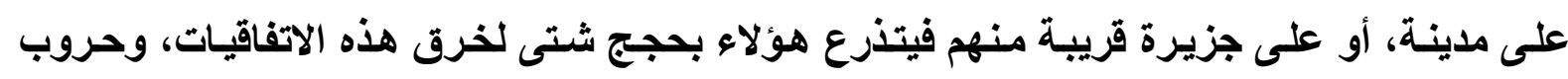

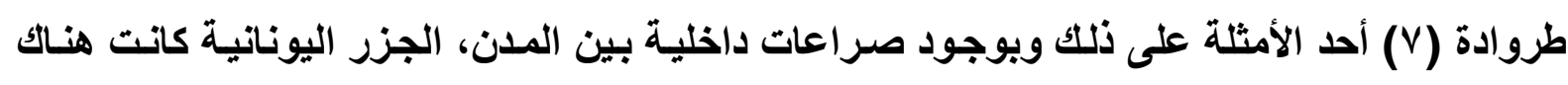
أيضا حروب بين اليونان وبلان اخرى حيث كسان اليونانيون يدعون سكان البلدان الأخرى بـالبرابرة

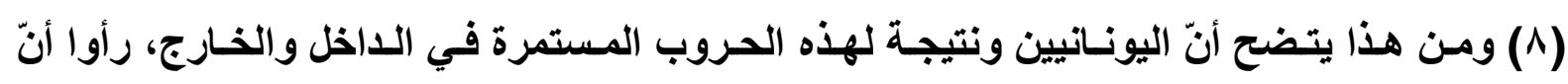

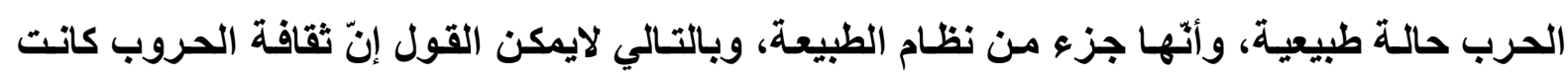

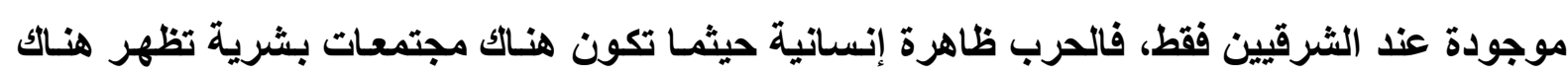

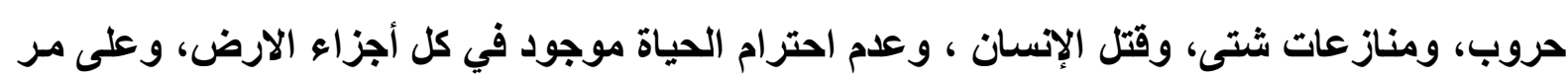

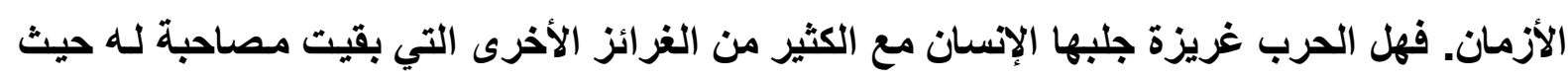


كان في حالة الطبيعة؟ أي: قبل أنْ يتحول الى حالة الوعي الإنساني، وحالة التمدن التي نعرفها آلان؟

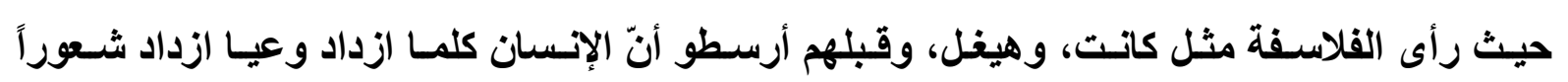

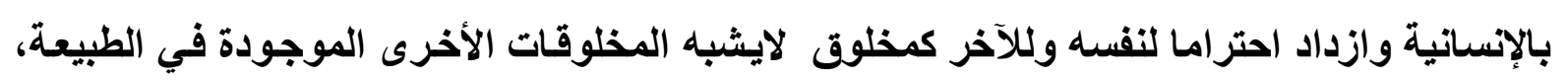

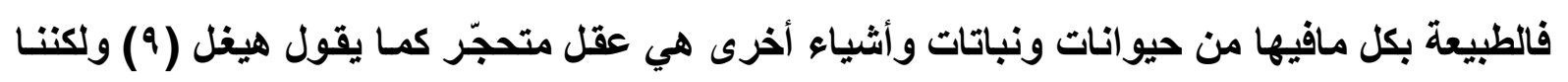

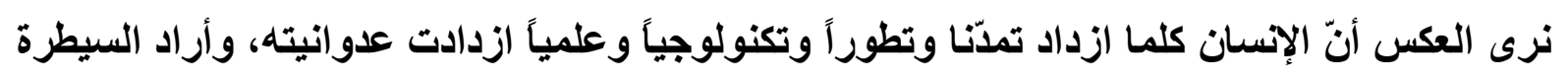

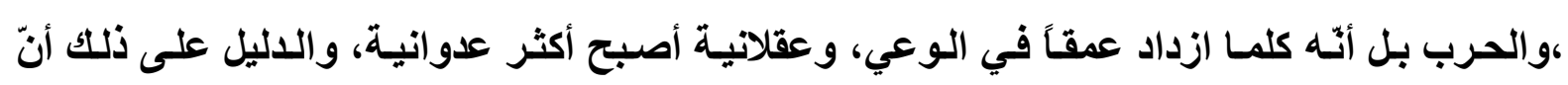

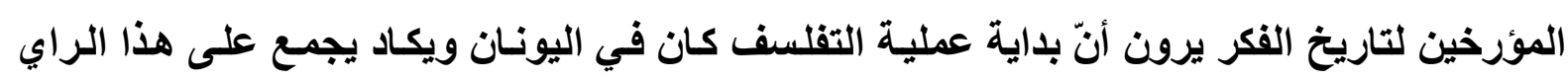

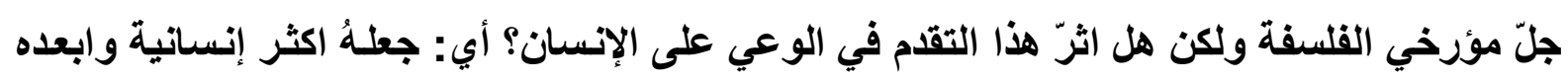

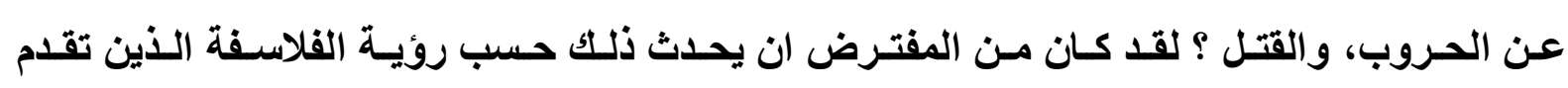

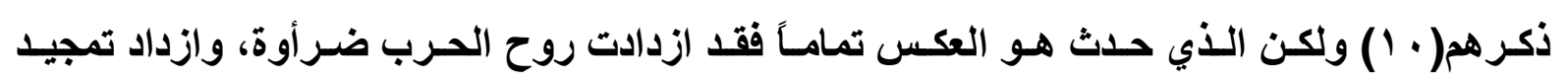

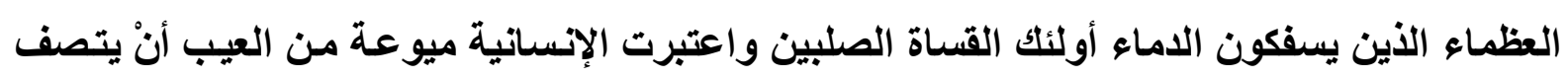

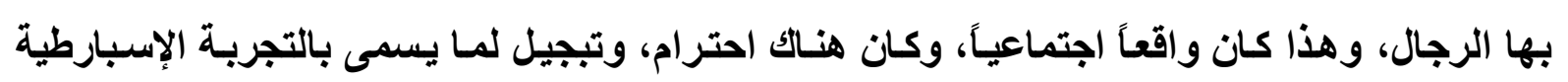

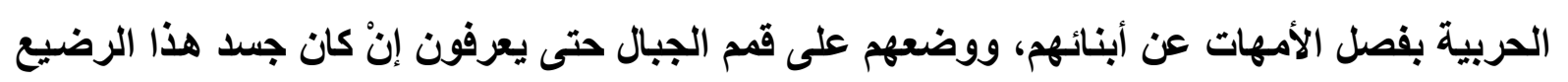

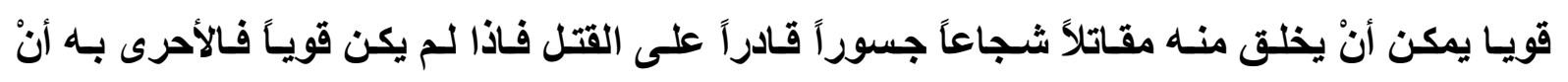

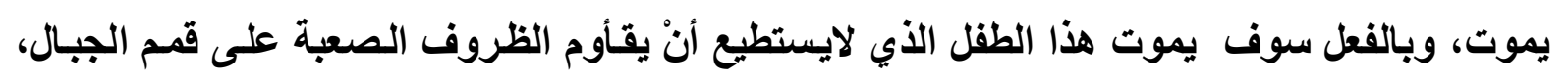

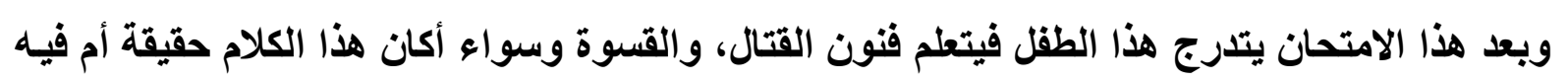

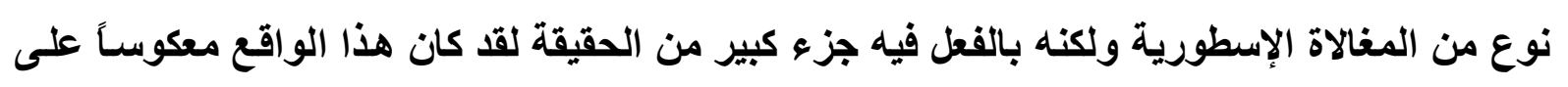

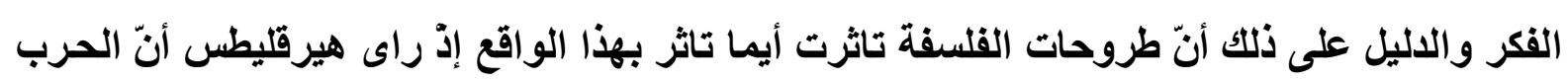

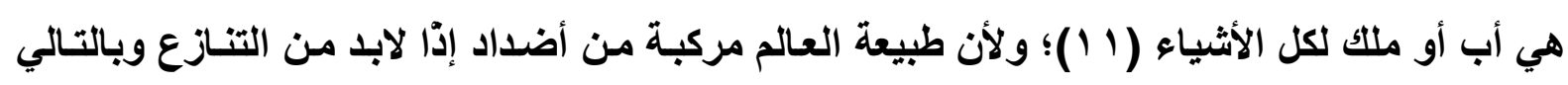

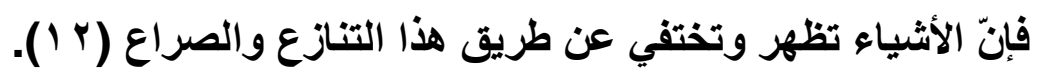

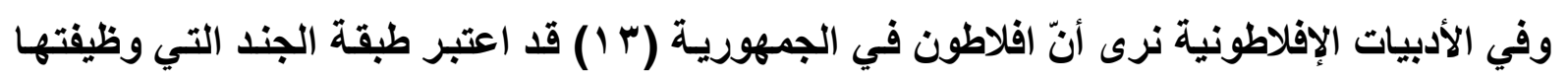

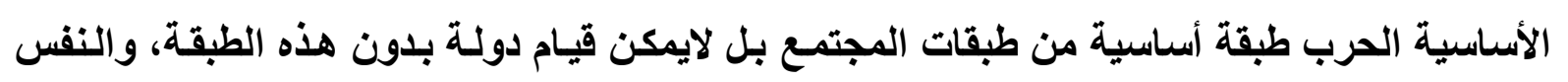

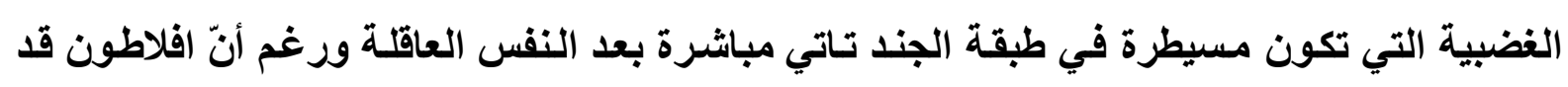

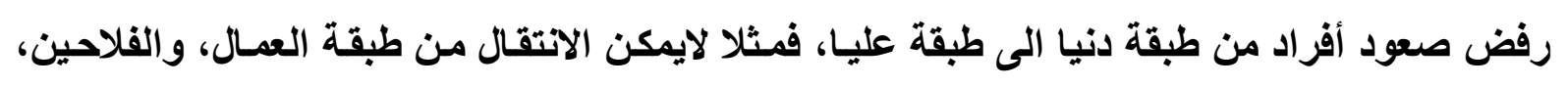

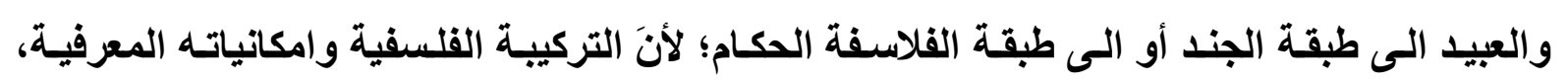

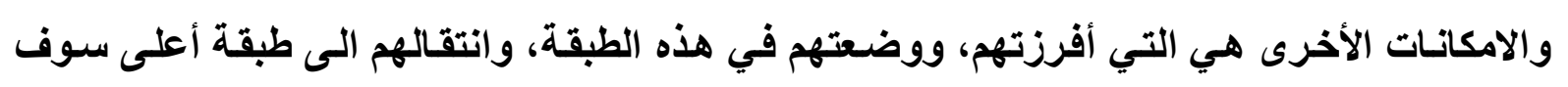

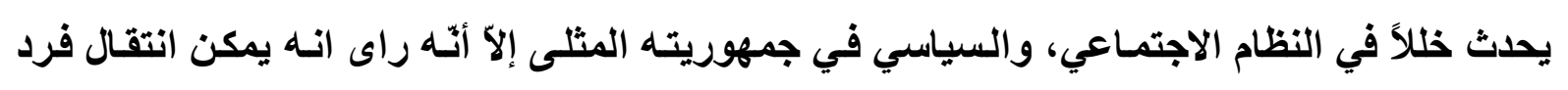

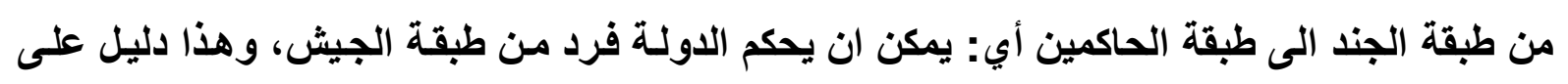

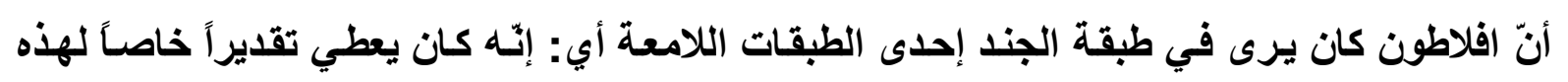


الطبقة، ورغم أنّ افلاطون كان يؤمن بمثل عليا هي الحق، والخير، والجمـال إلا أتّهـ لم يرفض الحرب

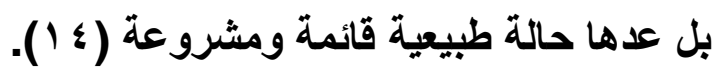

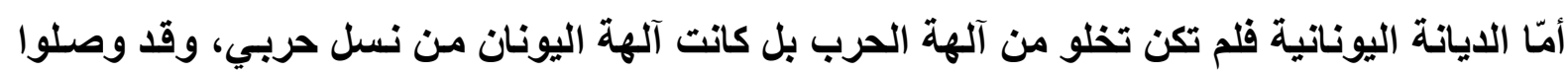

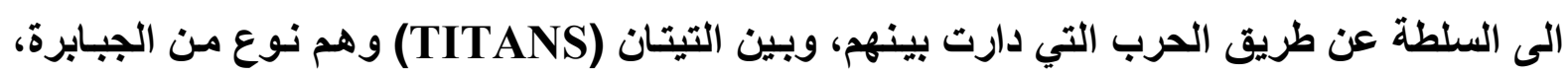

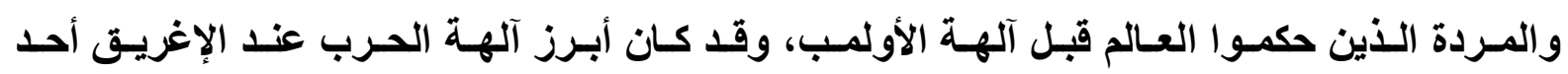

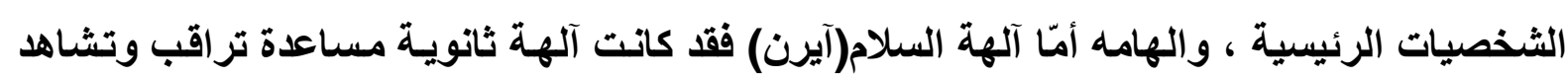

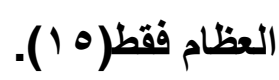
أمّّا على مستوى الايانات السمأوية الكبرى الثلاث اليهودية، والمسيحية والإسلام فقد كاتت اليهودية دين حرب بامتياز، ولعلّ هذا راجع الى طبيعة تكوينهم كثعب، فالثعب اليهودي ينسب نفسه من أصل

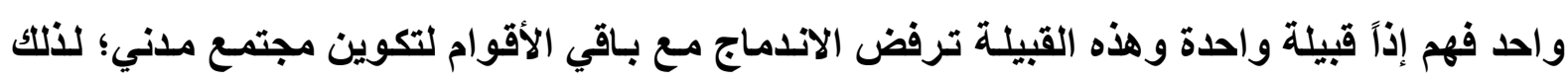

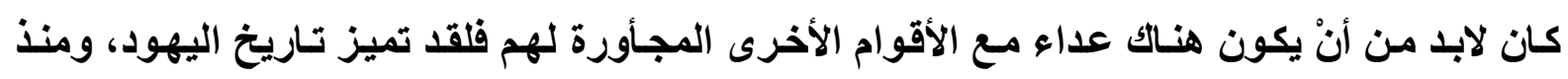

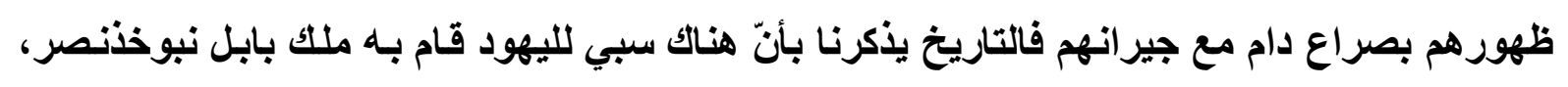

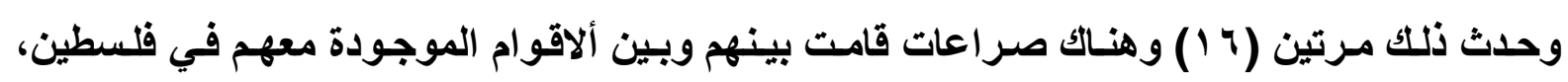

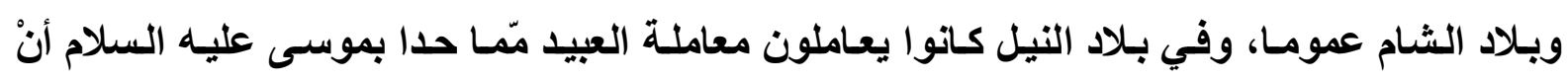

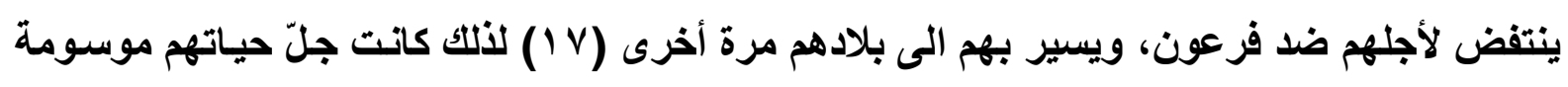

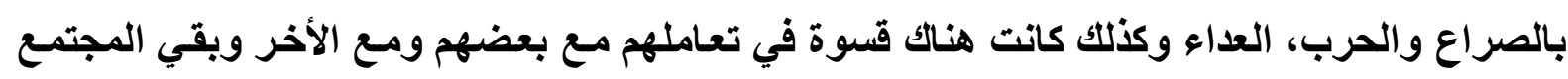

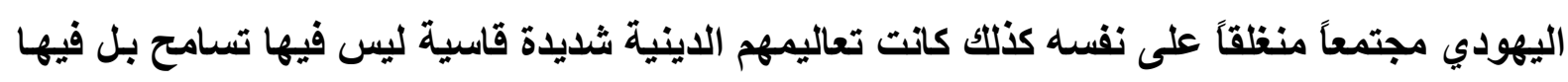

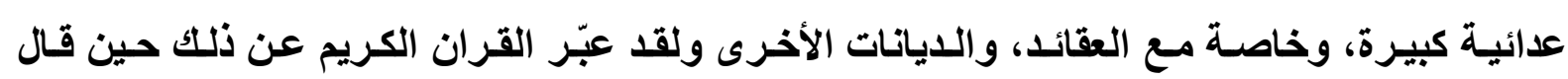

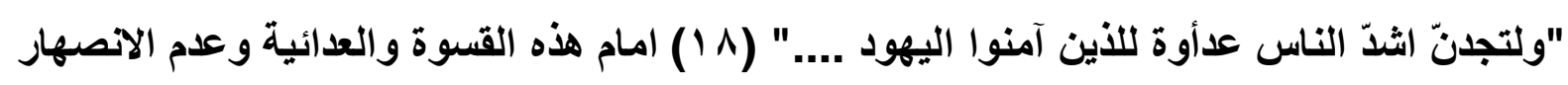

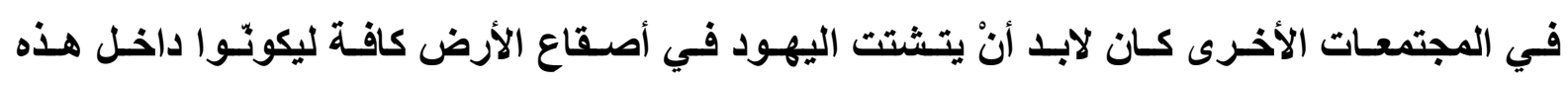

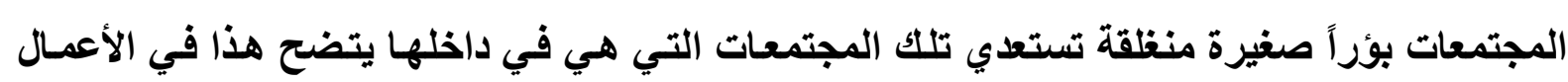

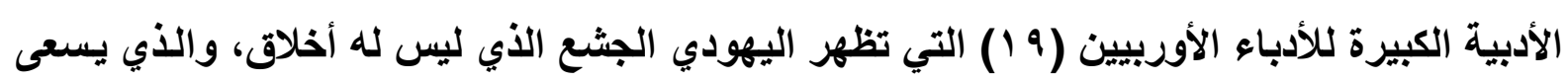

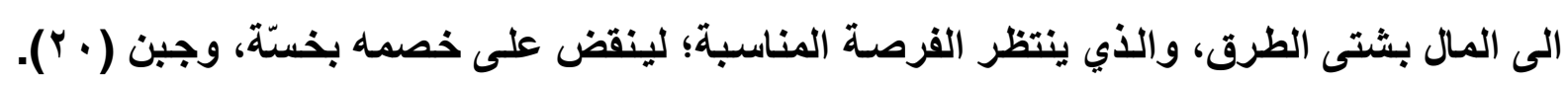

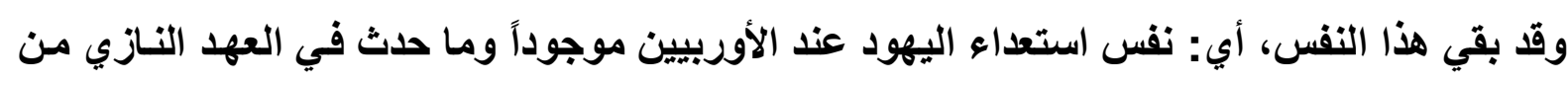
قتل، وتنكيل باليهود دليل على ذلك، وبوجه عام كاتت العقيدة اليهوديـة هي عقيدة حرب، واستعداء

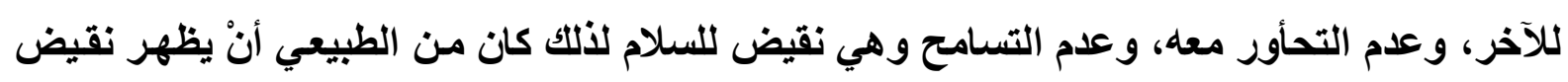
من هذه العقيدة من داخلها ونقصد بذلك المسيحية .

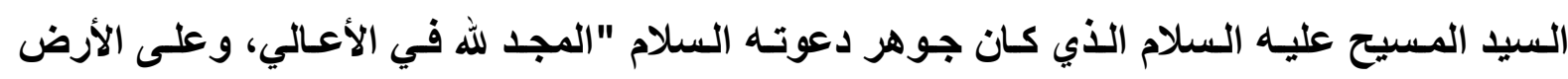

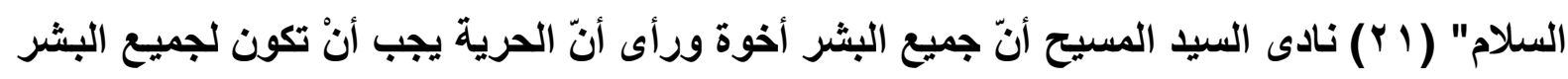


ودعا الى مجتمع بشري واحد تسوده المحبة، لاتفرق بينهم، لاجنس، ولا لون، ولادم، ولالغة ..الخ.

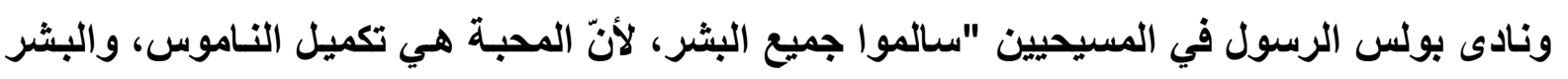

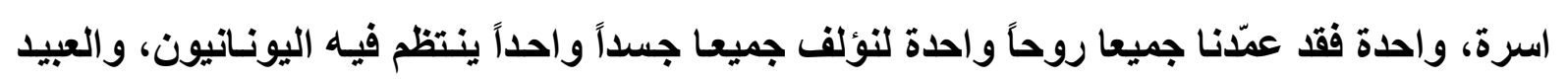

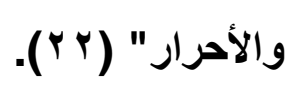

ولكن المسيحية فيمـا بعد حينمـا تحولت من رسـالة محبة وسـلام الى دولية، أو دول أي: الى سياسـة

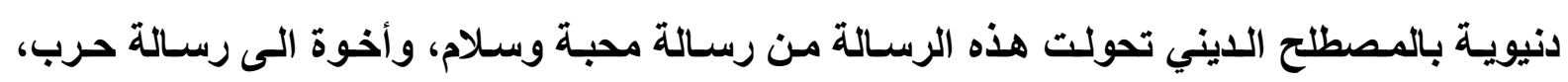

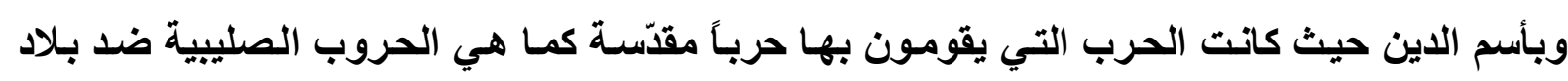

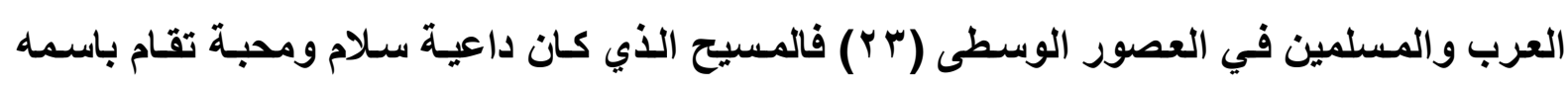

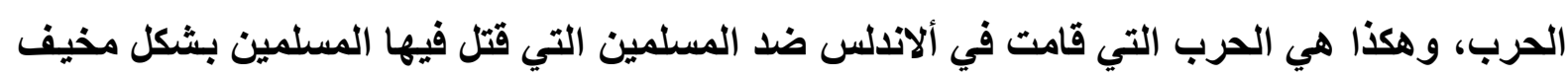

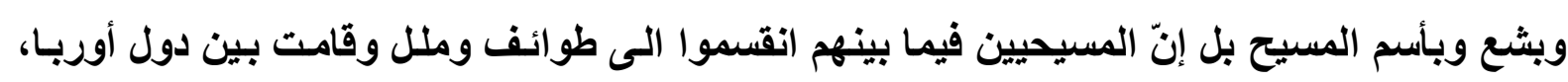

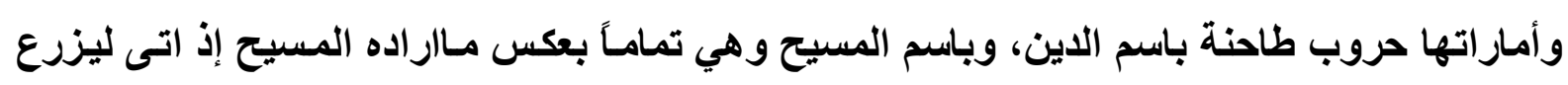

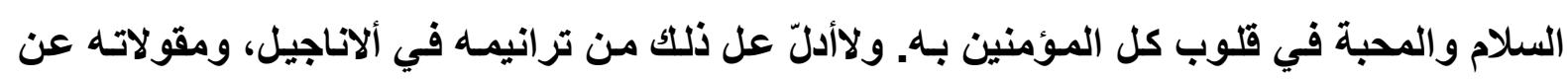

$$
\text { السلام التي تمثل جوهر رسالته (ع ب). }
$$

أمّا موقف الاسلام من الحرب فيبدوا أنّ الإسلام هو التركيب، أو مركبّ النقيضين بـالمفهوم الهيغلي

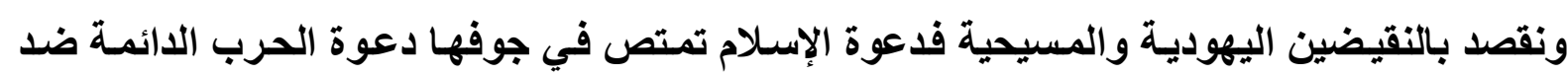

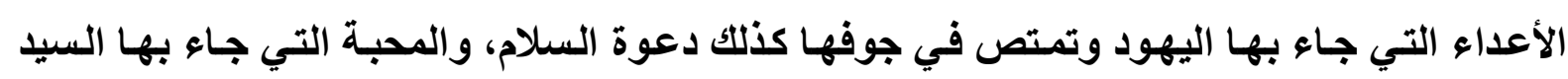
المسيح لتمتزج في موقف متوازن عن الحرب، والسلام فنظرة فاحصة الى آيات القران الكريم نجد

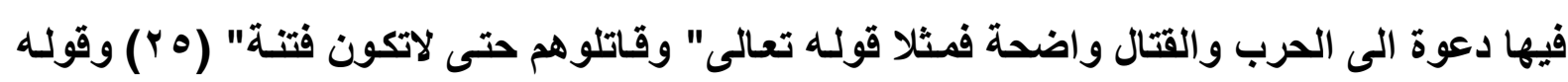

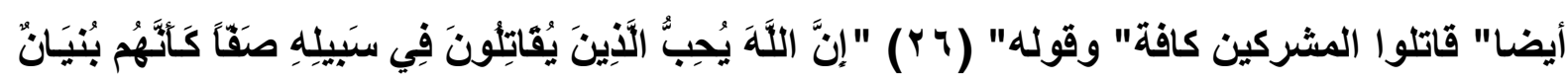

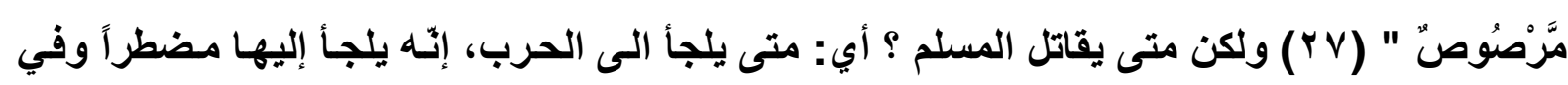

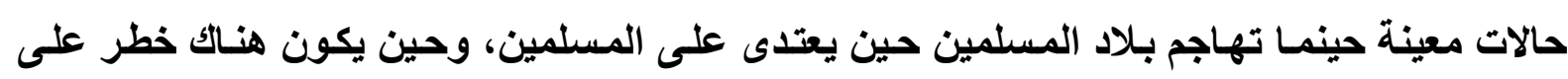

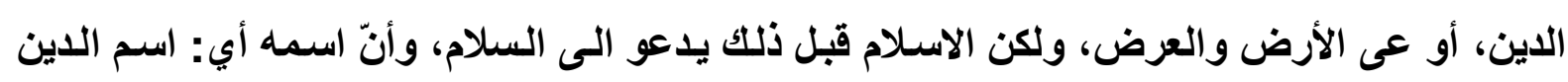

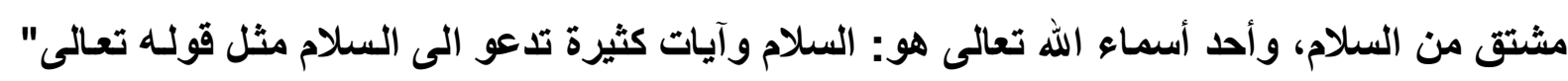

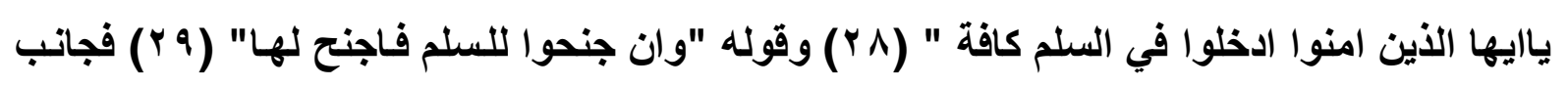

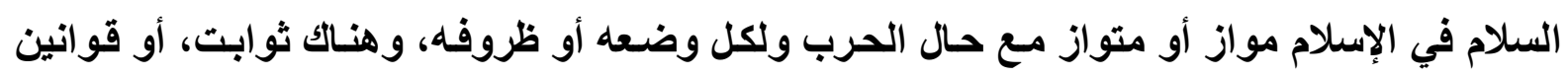

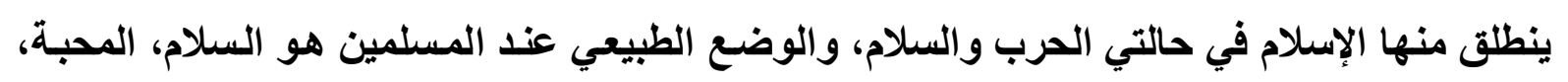
الاخوة، وخاصة مع أبناء الديانات السمأوية الأخرى وهو أقرب الى المسيحية منها الى اليهودية.

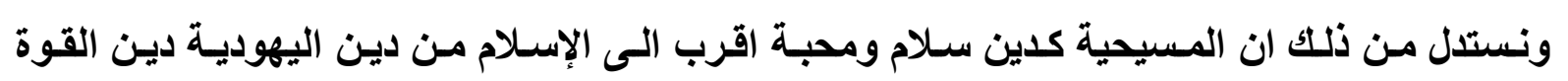
والثدة والحرب، ولكن الإسلام لم يرفض الحرب بل جلها مقدة، وفريضة كمـا هي فريضة الجهاد 
في سبيل الله ولكن مرة أخرى نقول إنّ الحرب في الإسلام هي حالة استثنائية وليست حالة طبيعية من هذا نجد أنّ الإسلام قد وازن بين الفكرتين الحرب والسلام ليرتقي الى فكرة ارقئ.

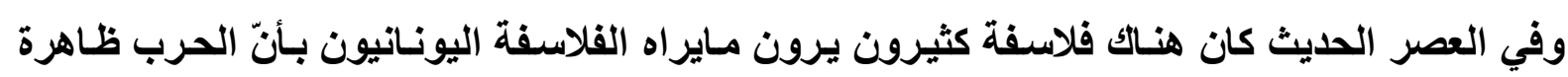

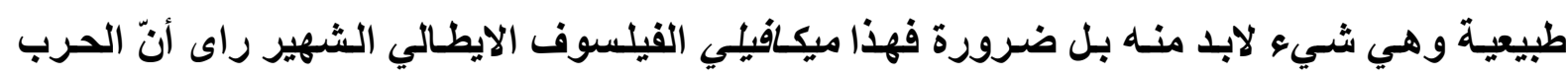

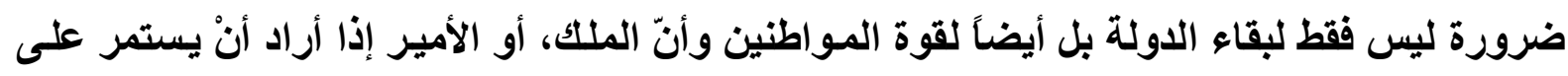
سدّة الحكم لابد أنْ يكون جلّ تفكيره في الحرب وليس في السلام( • ب).

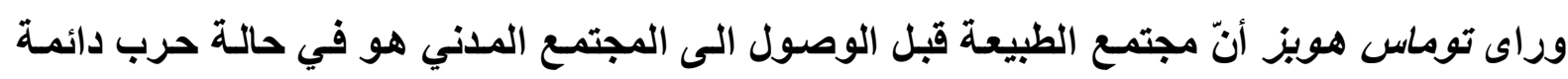

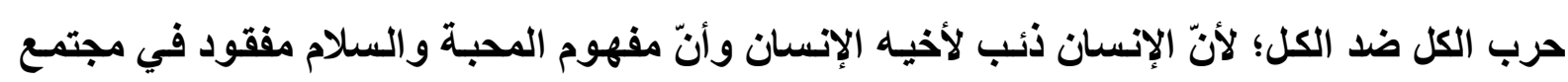

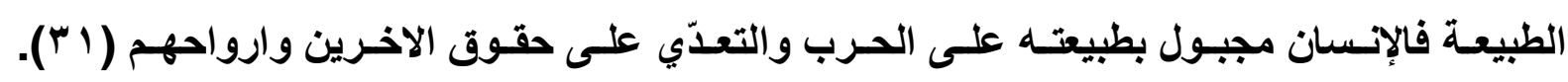

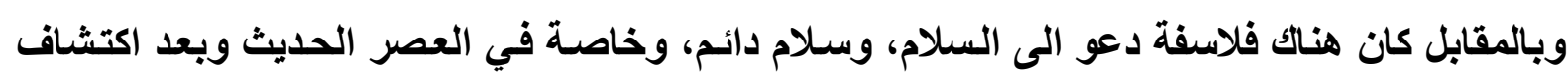

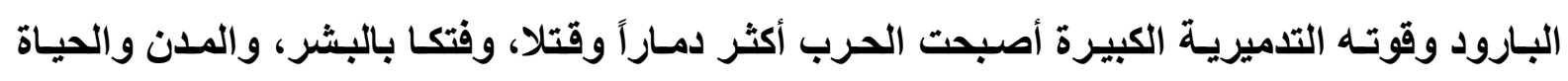

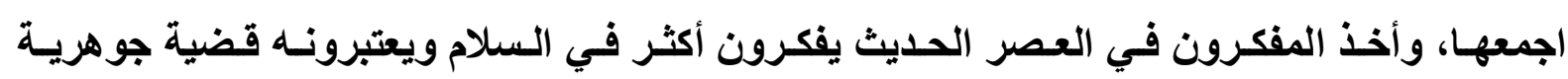

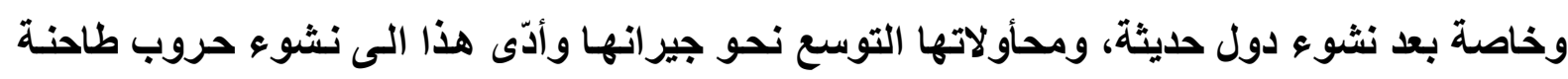

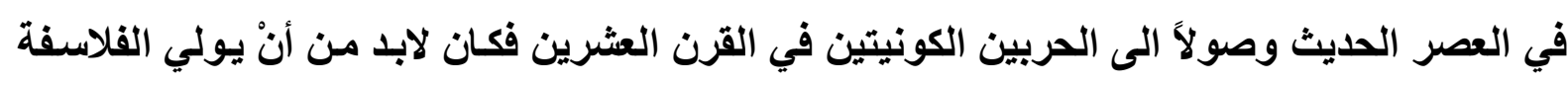

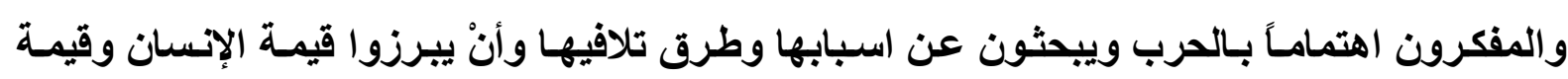

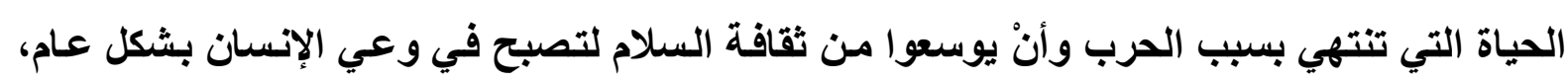
وأنْ يبرزوا مواطن الخلل، والضعف في ثقافة العنف الذي يؤدي الى الاستبداد وهدر كرامـة الإنسان

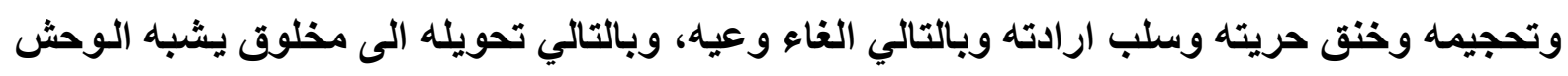

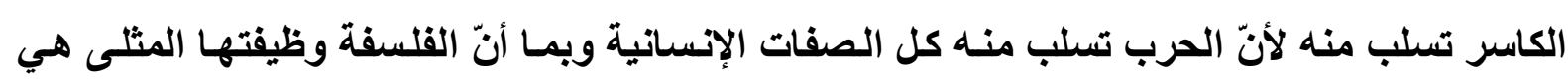

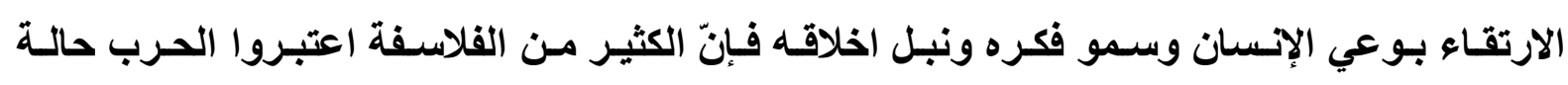

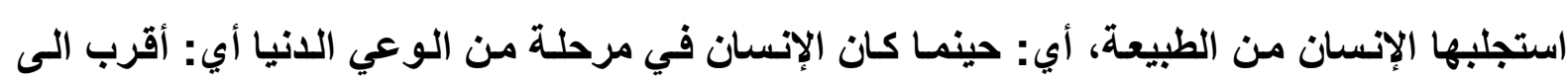

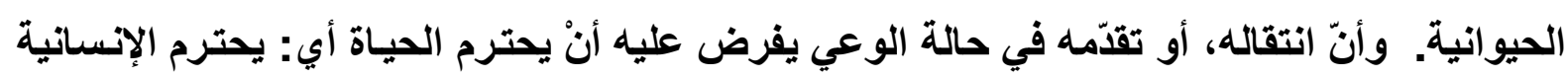

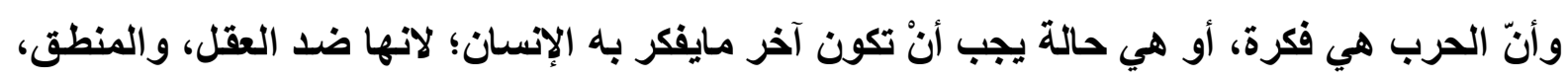

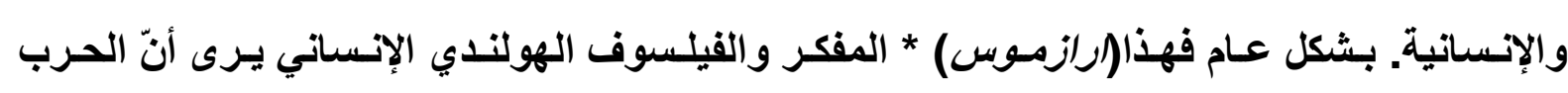

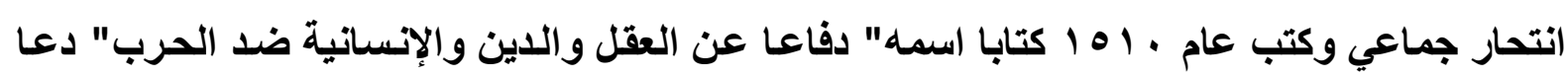

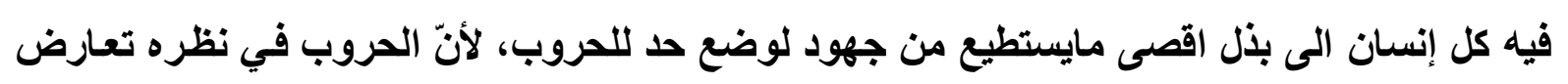

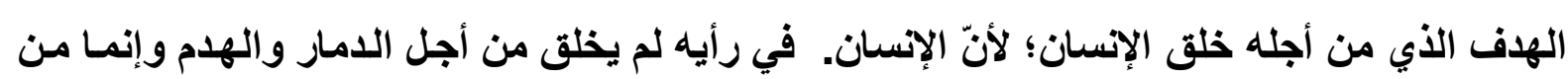

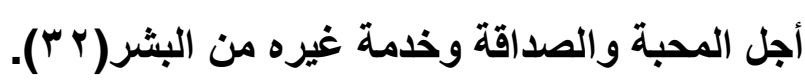


إنّ السلام يجب أن يكون ثقافة، وليست ردّة فعل ضد الحرب أي: يجب أنْ يكون في وعي الإنسان

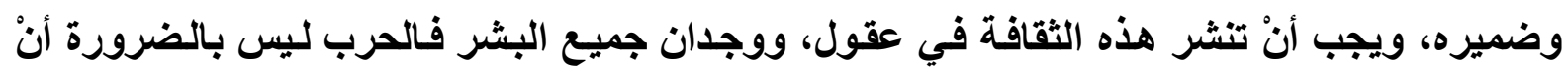

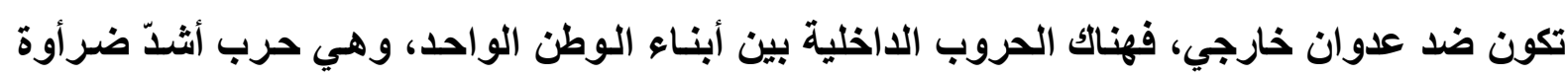

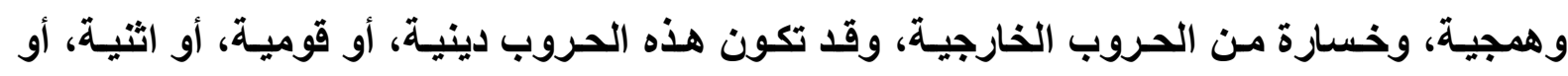

مناطقية .

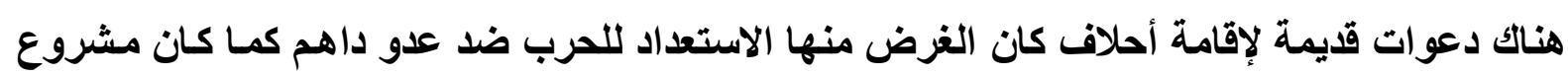

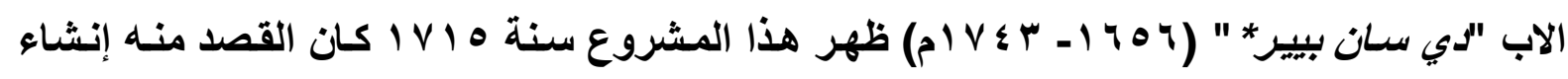

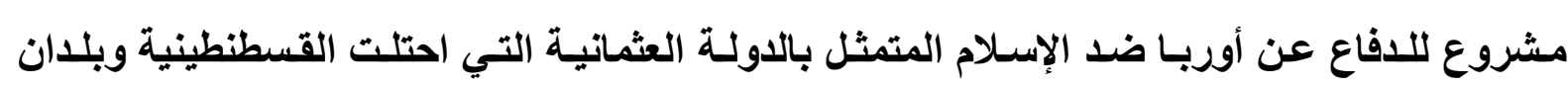

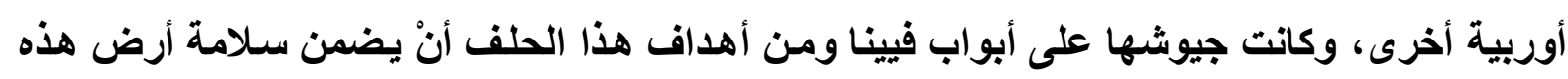

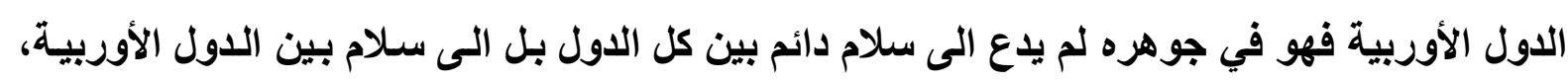

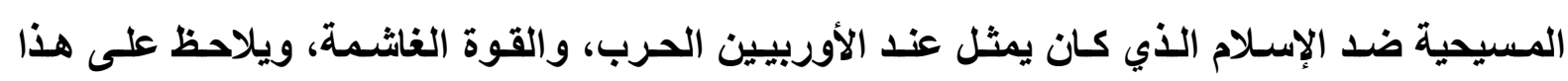

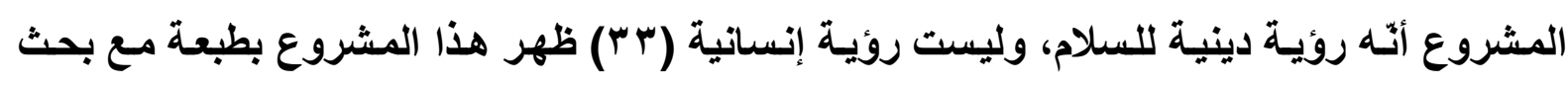

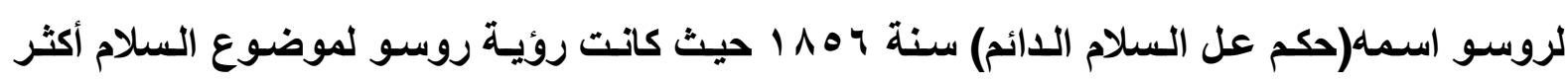

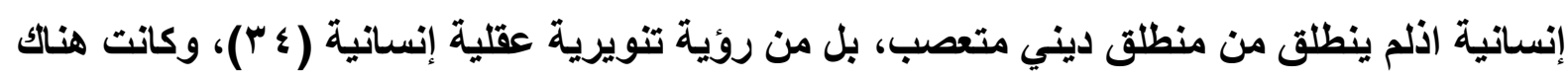

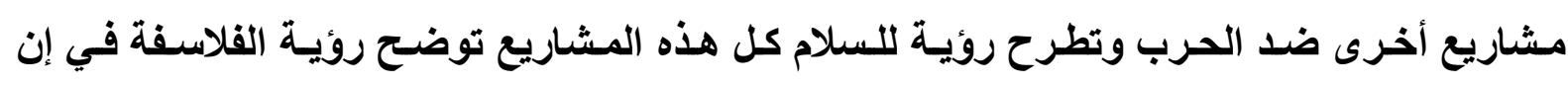

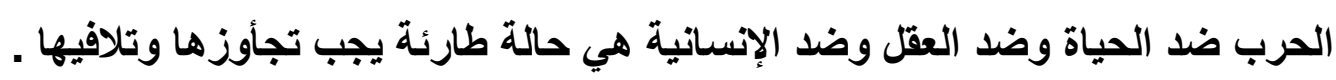

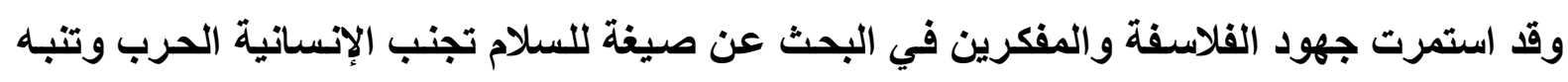

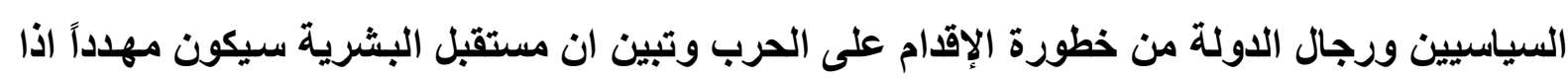

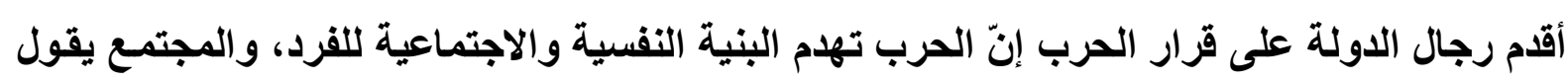
كتاب ت" ف " كان

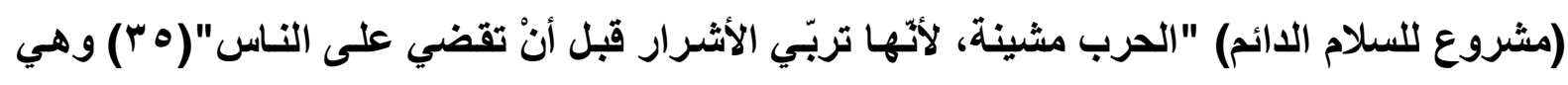

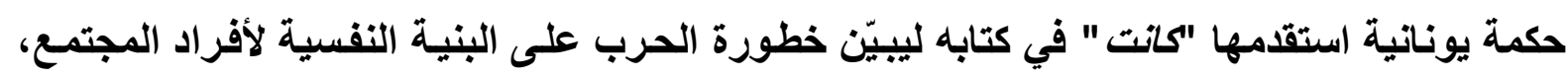

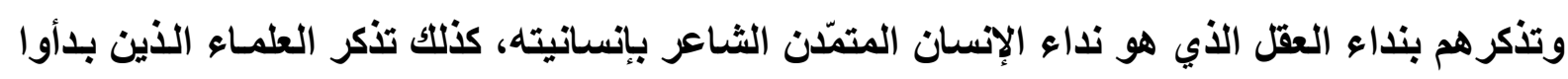

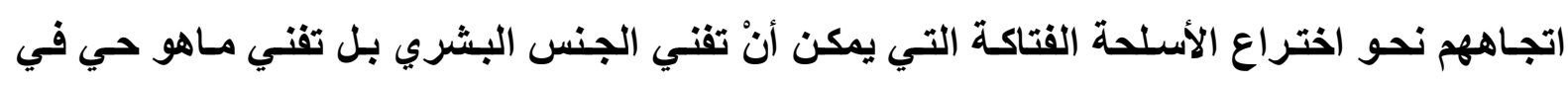

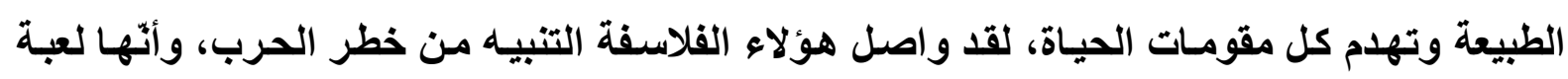

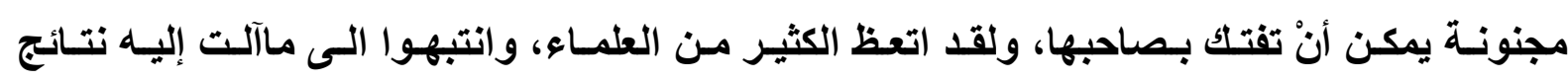
مخترعاتهم من ضرر على البشرية، وعلى الحضارة، ونوبل خير مثال على ذلك حيث لازالت هنـالك

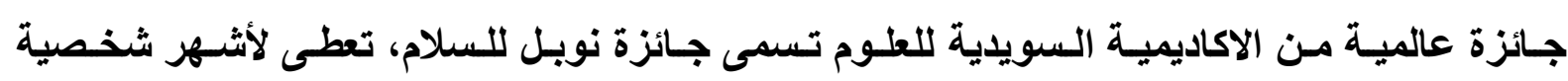

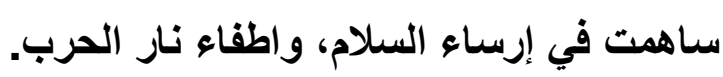


كانت، موقفه من الحرب والسلام

آمن كانت مثل روسو بضرورة قيام عقد اجتماعي، يحمي الناس من خطر الحروب التي يمكن أنْ تقوم

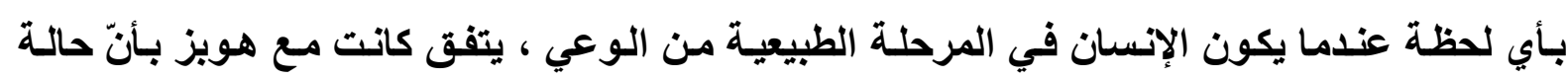

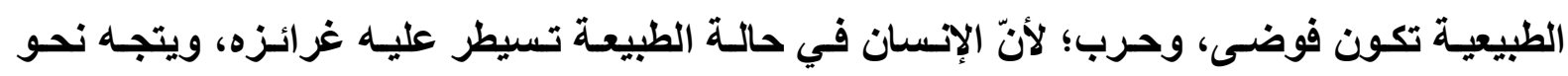

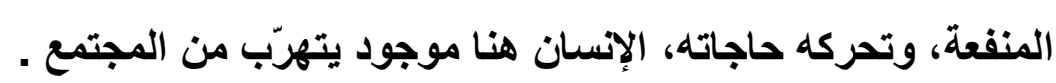

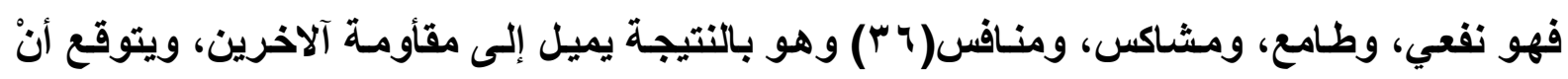

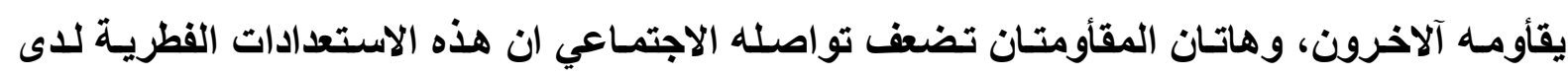
الإنسان تنفعل في عالم الطبيعة لكن هذه العملية تمر بمخاض عسير. فالطبيعة ميدان الاختلاط بين الأنئ

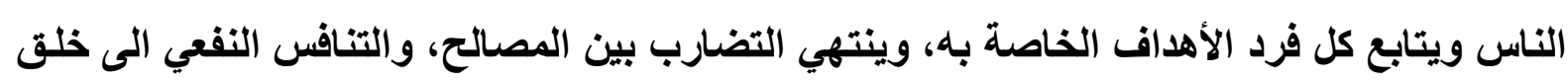

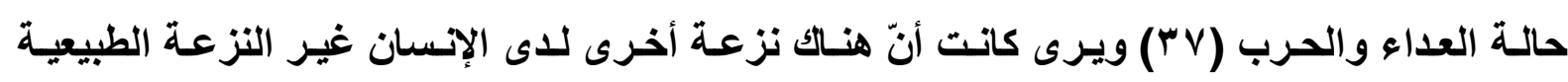
الغريزية فالإنسان بالرغم من ميله الطبيعي الغريزي موجود عاقل، وعقله قوة تدفعه الى التفكير فيمسا وراء الطبيعة. إنّ الإنسان كما يرى كانت موجود مبدع، وخلاق يستخدم عقله في إبداعه وانتاجها أنّ العقل موهبه.

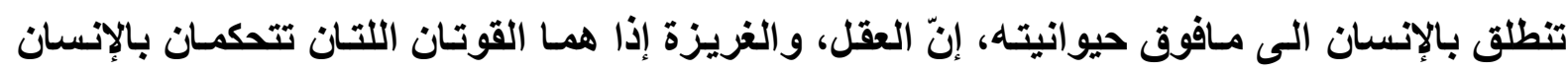

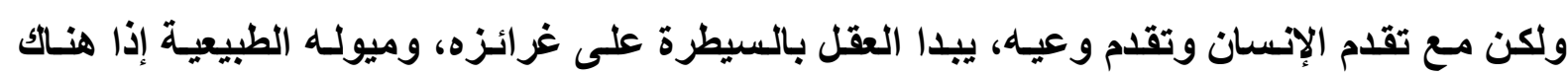

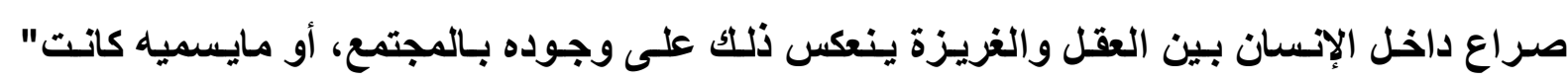

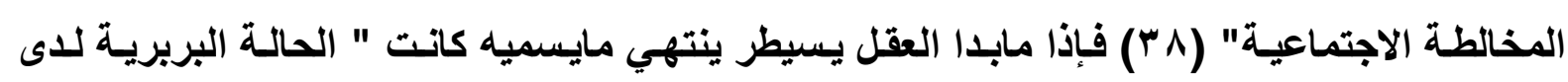
الإنسان" ويتجه نحو الثقافة التي تعبر عن الجدارة الاجتماعية لاى الإنسان ويندفع الإنسان في عملية

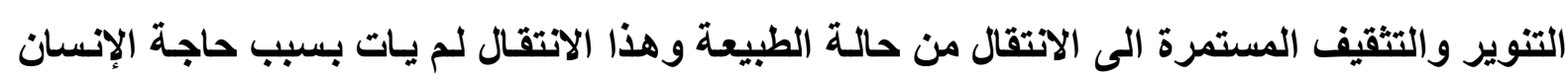

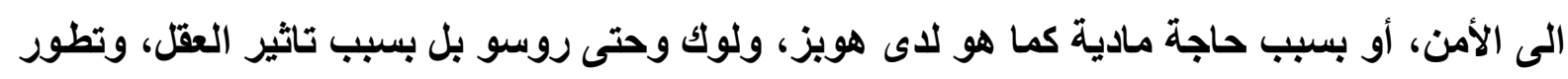

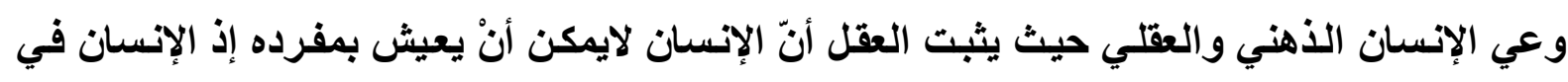

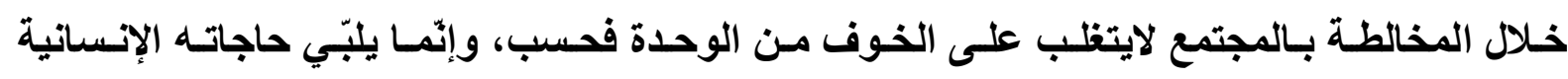

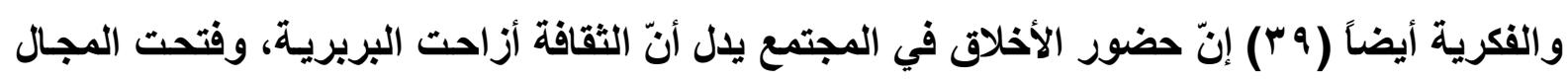

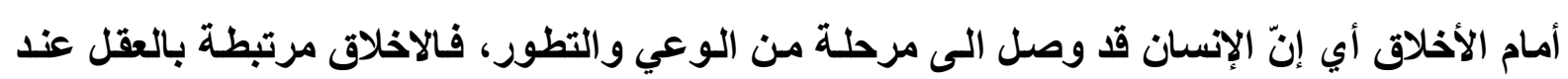
كانت فكلما تطور عقل الإنسان ادرك القانون الاخلاقي.

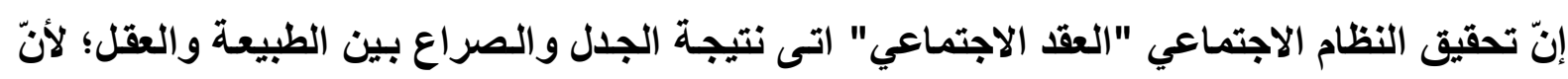

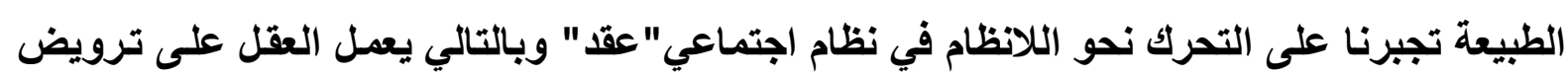

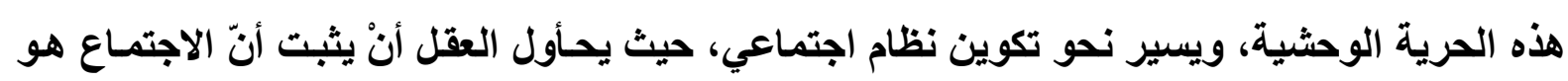

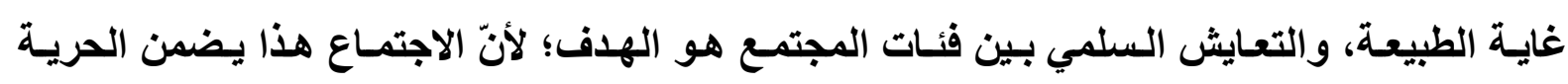


للجميع مع وجود الاختلافات بين البشر حيث يحأول العقل أنْ ينسّق، أو يضمن حريات الآخرين مـع

$$
\text { عدم الحاق الضرر بحريتك ذلك من خلال رسمه حدود الحرية والدفاع عنها ( • ع). }
$$

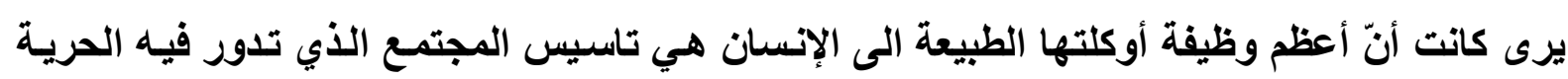

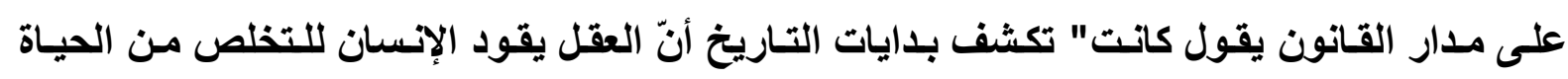

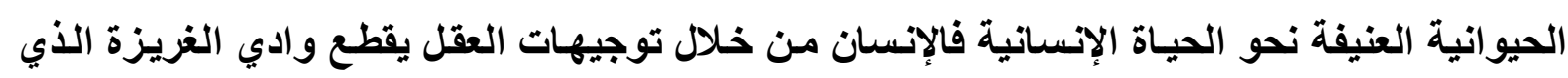

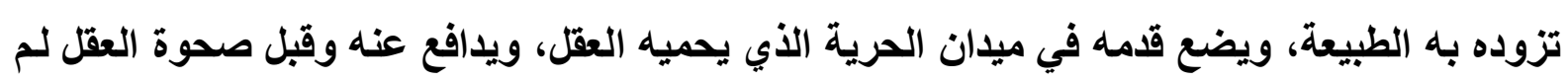

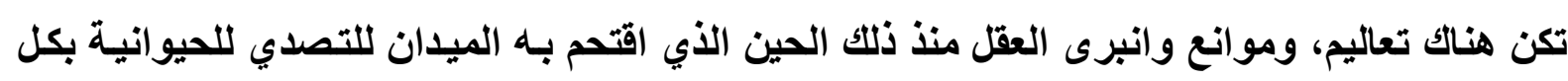

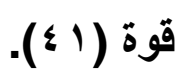
الإنسان والحرب من وجهة نظر كانت ينطلق كانت من مفهومين جوهريين لتوضيح علاقة الإنسان بالحرب همـا: مفهومـا الأخلاق والحريـة؛

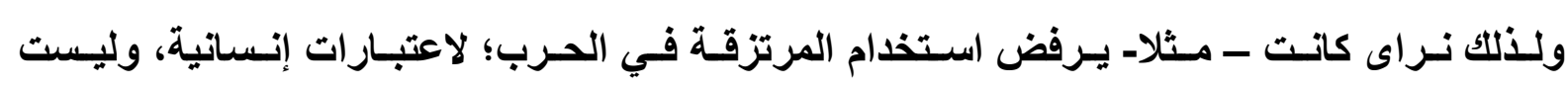

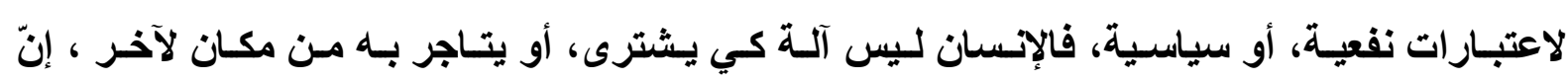

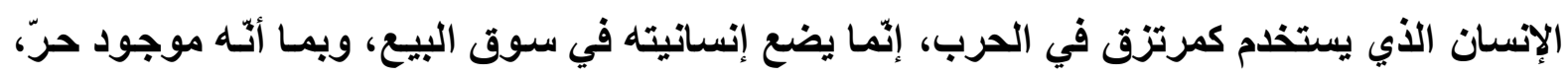

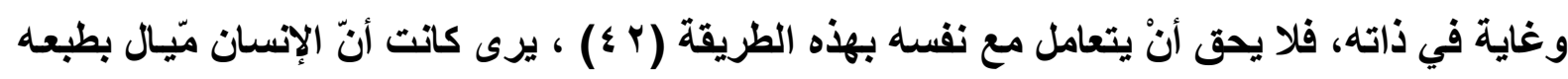

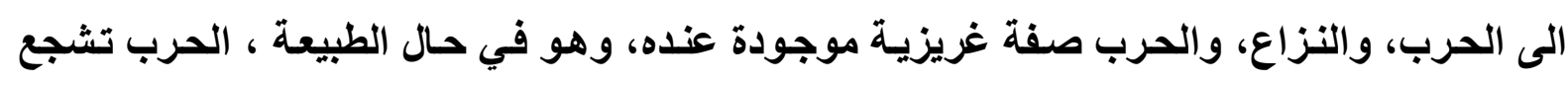

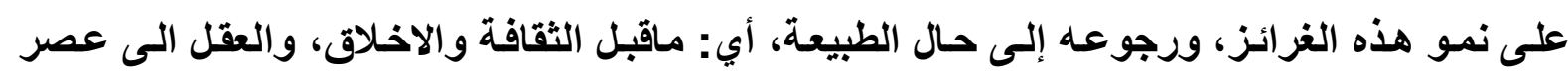

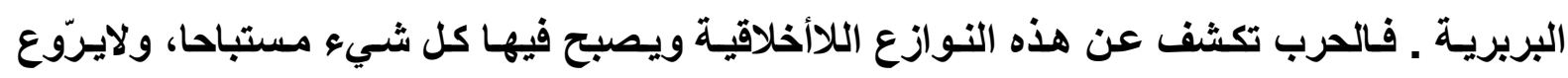

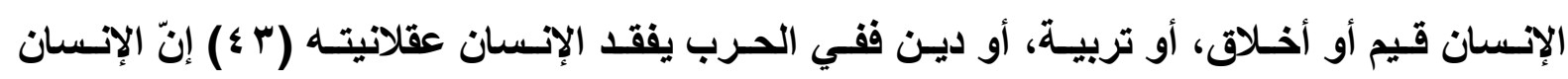

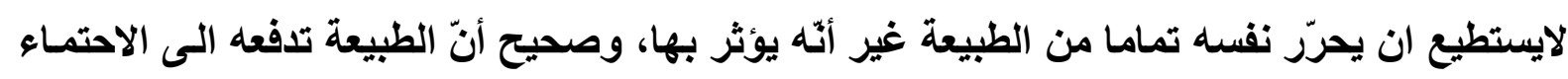

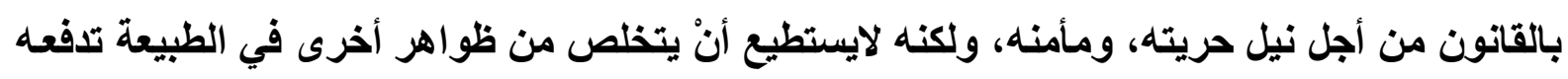

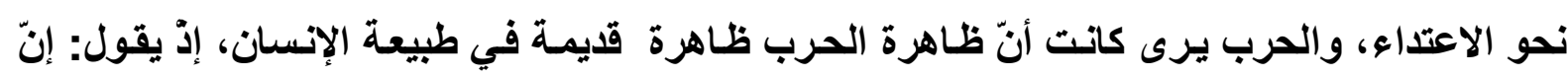
الحرب ترجع بالإنسان القهقرى الى حالة الطبيعة الى حالة العدوان، والعنف وكل القيم غير الإنسانية.

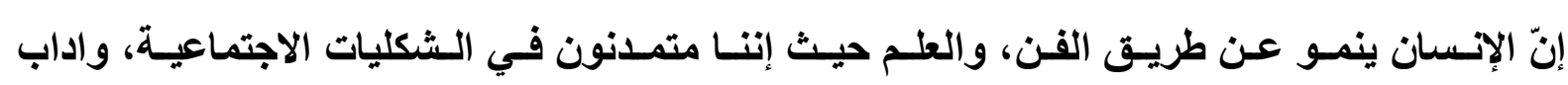

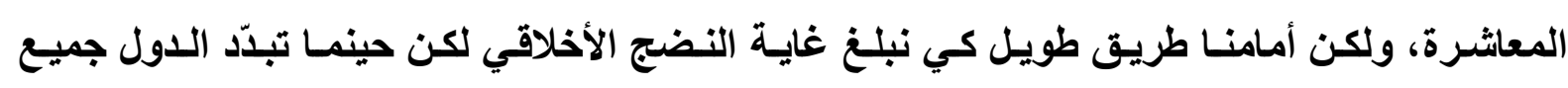

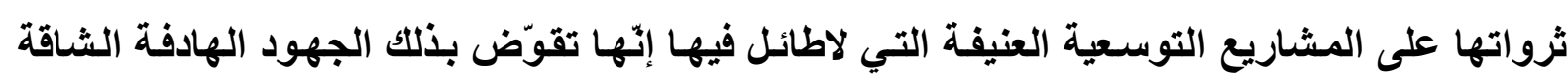
التي يبذلها المواطنون لإنماء قواهم الفكرية" (ع ؛ ؛ ).

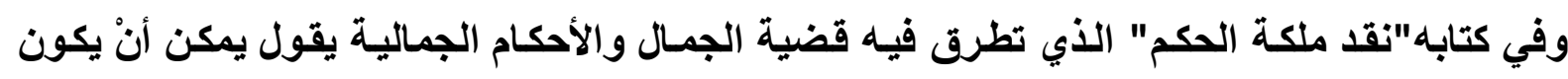

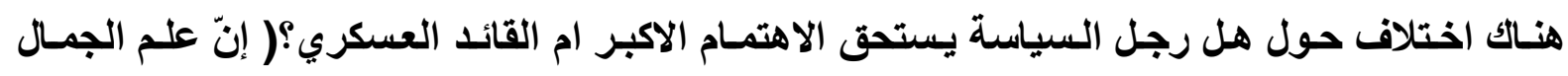

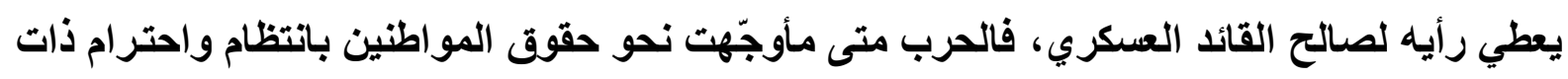


هدف مقدس وسمة شخصية الشعب الذي يدير تلك الحرب بنفس النسبة التي يواجه بها الأخطار ويتعامل معها بشجاعة، من ناحية أخرى يؤدي السلام الدائم عمومـاً الى تقلب روح النفعية، والأناتية الأليلة، والمرونة النسوية، وانجرار شخصية الشعب نحو الانحطاط)(0 ؛ ) قد يبدو هذا الراي غريبًا. عن الطروحات الكانتية حيث إنّ النفس الكانتي ومجمل طروحاتـه تصب في مصلحة السلام، وذلك انطلاقا من روئيته المعرفية والأخلاقية التي ترى أنّ الحرب تتـاقض مباديء العقل، وتــاقض الأخلاق؛ لأنها تنمي الجاتب الثرير، والسيء في الإنسان إنّها تنمي غرائز الطبيعة. والإنسان كلمـا ازداد وعياً، وثقافة، وتحضراً، التجأ الى القنون، أقبل نحو السلام، والعكس صحيع. يرى كانت أنّ ملكة الوجدان (7 \& ) التـي هـي وسط بين ملكـة الفهم والإرادة توضـح معنى الشعور الملاتـم، وغيـر الملائـم، وهي مرتبطة بالوجدان. أي: إنها مرتبطة بصفات الإنسان الطبيعية، وليس صفاته العقلية، وبالتالي فـإن

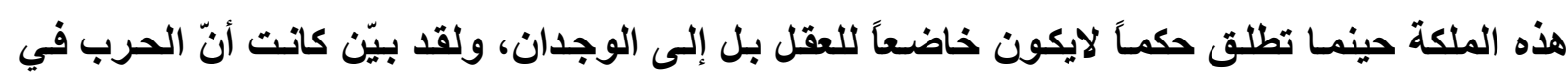
طبيعة الإنسان. أي: في وجدانه، وبالتالي فان هذا الوجدان لايرفض الحرب بل يقدسه وهو في آخر المطاف يحترم المحارب أكثر من السياسي، فـاذا مـا اعتبرنـا الوجدان هو بطبيعة الإنسان فـإنّ طبيعة الإنسان تتجه نحو الحرب لا نحو السلام، وبذللك نرى كانت في كتابـه (مشروع للسلام الدائم)يتحدث عن إجبار الطبيعة كأحد الضمانات لتحقيق السلام، والسلام واجب أخلاقي ينبثق عن العقل العملي، لامـن طبيعـة الإنسـان، إنّ "كانـت" في النص السـابث يقترب مـن هيغل إدّ راى أنّ الحـرب تسمو

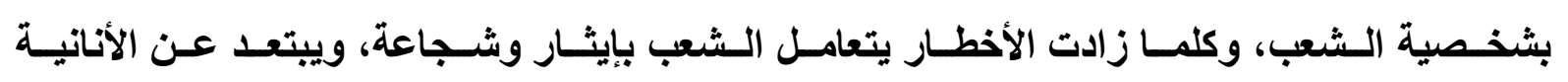
والمصلحية، وتتظلب روح الجماعة، وحب الوطن على المنافع الثخصية، وهو عكس مايفعله السلام الدائم في روح الثعب، إذّ تتظلب الأنانيـة الذليلة، والليونة، والاسترخاء ولعلّ موقفه هذا من الحرب غير معروف على مستوى كبير؛ لأنّ مـا هو معروف عنـه أنّهـ فيلـسوف سـلام اعتبر الحرب حالـة

استثنائية أو حالة تناقض القانون الأخلاقي(V \& ). أسباب الحرب من وجهة نظر كانت يرى كاتت أنّ علاقة الدول فيمـا بينها أثبه بعلاقة الأفراد فيمـا بينهم في حالة الطبيعة، فهي علاقة يكتنفها العنف، وصراع المصالح، ولايوجد هناك قانون يحمم هذه الدول، ويفض النزاعات فيما بينها، ويقول في ذلك: تعيش الدول في علاقاتها الخارجية مثل الهمج الذين لاقانون لهم في وضع عـار عن الحق" (^ §) إنّ الدولـة في الوضـع الطبيعي ترى نفسها في ظل حرب مستمرة مـع الدول الأخرى والعلاقـات فيمـا بينهـا معقدة، بـل هي أثـدّ تعقيداً من علاقة الأفراد فيمـا بينهم في الوضـع الطبيعي، وتكون هذه العلاقات على ثلاثة انواع هي: ا ـ علاقة دولة بدولة أخرى. r - علاقة دولة مع أفراد دولة أخرى. 
r- علاقة أفراد دولة مع أفراد دولة أخرى.

و السبب الثاني كمـا يرى كانت لقيام الحرب هي الأنظمة الاستبدادية التي تكون من طبيعتها التوسع،

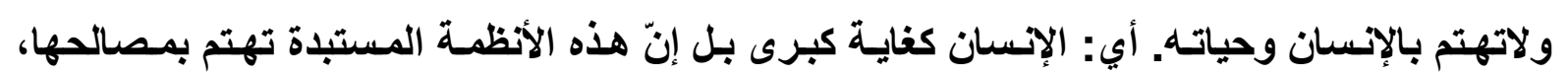

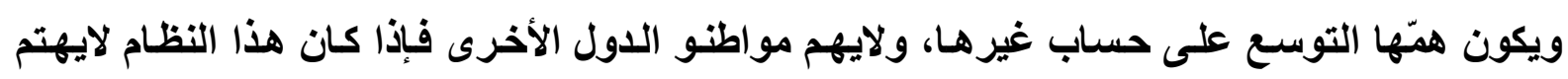

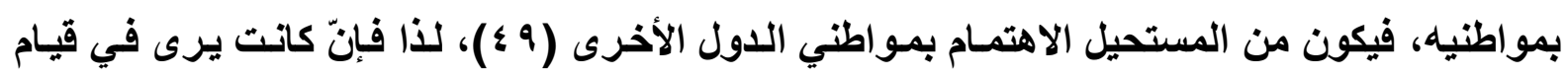
نظام جمهوري نيابي ديمقراطي خطوة مهمة في تحقيق السلام، وإنهاء الحرب، ويرى أنّه لايمكن قيّام

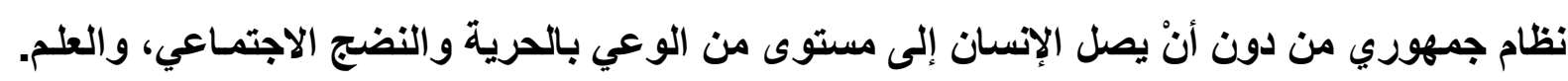

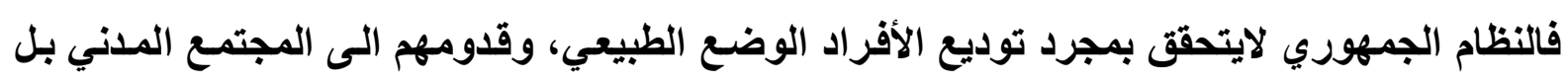

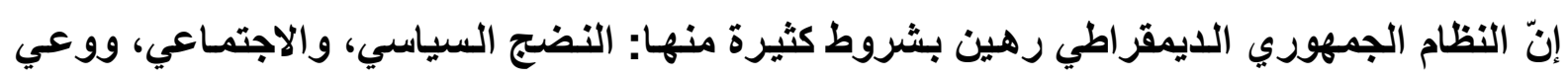

$$
\text { الإنسان بالحرية والمسؤولية (• (ه). }
$$

والسبب الآخر الذي يعدّه كانت من الأسباب المهمة لقيام الحرب هو الاقتصاد حيث أنّ انهمـاك الدول

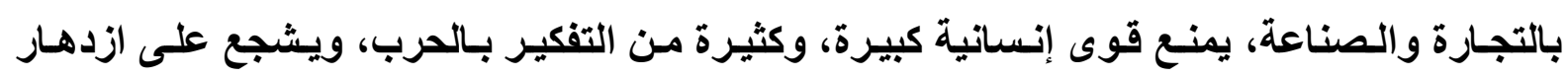

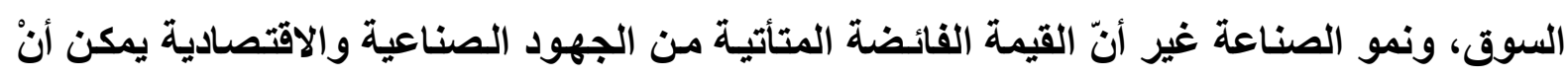

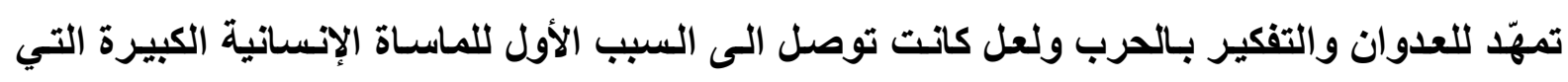
عصفت بالبلدان المتخلفة، والضعيفة التي استعمرت من قبل الدول الأوربيـة في العصور العديثة

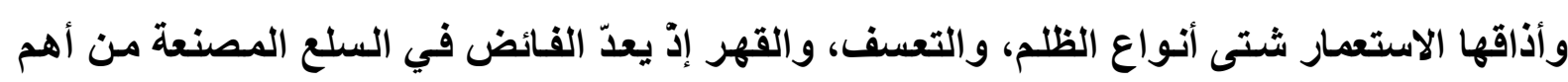

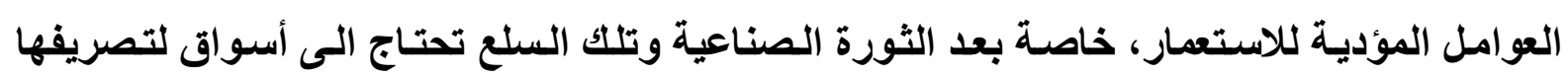

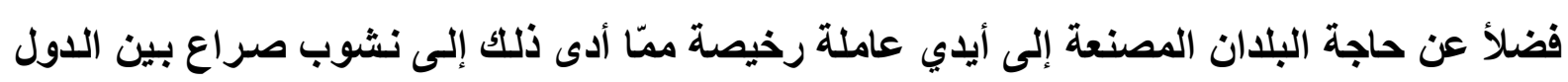

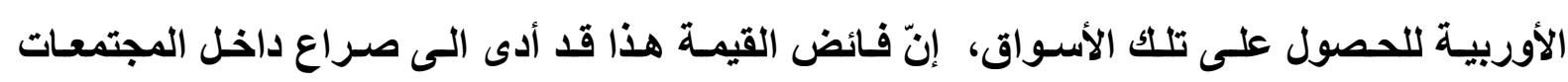

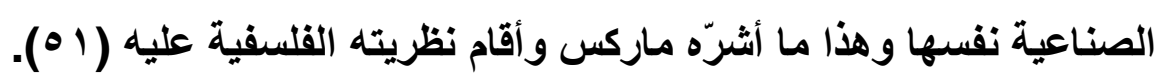

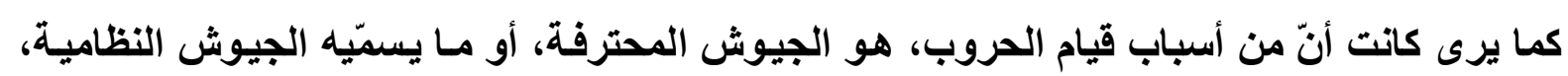

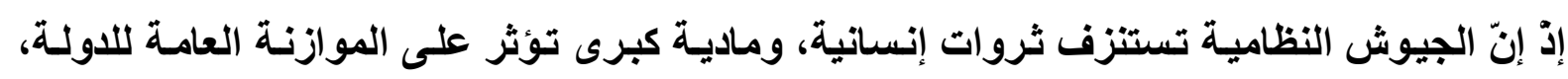

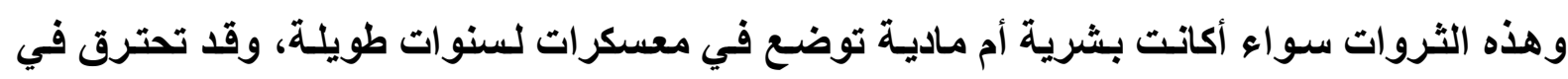

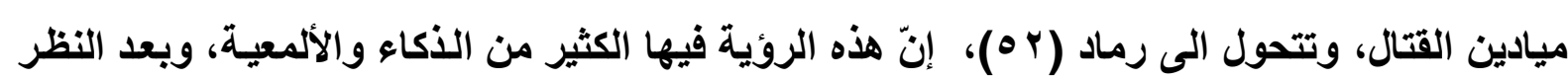

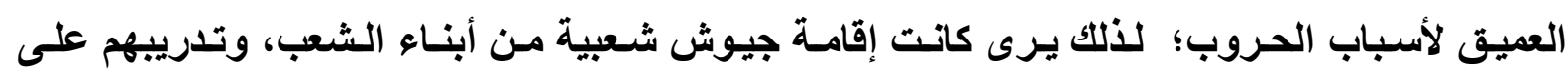

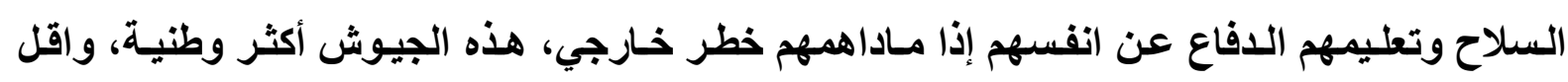

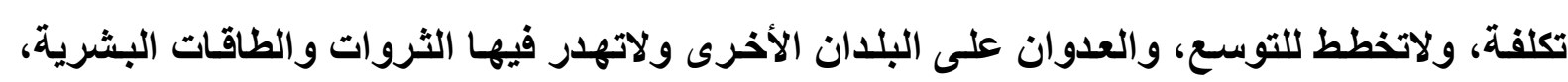
وهي تنهي هاجس العدوان، والحرب بين الدول. ضرورة الحرب في الفكر الفسلسفي الهيغلي 
يعد هيخل من الفلاسفة الذين يؤمنون بأنّ الحرب ضرورة، وأنّها موجودة في طبيعة الإنسان، ولايمكن تلافيها، وهي ليست شراً أخلاقياً محضاً، وهذه الرؤيـا تمثل جوهر فلسفته، اذ يرى أنّه لايمكن قيـام وعي حقيقي، أو تقدّم في الفكر إلا بصراع ألافكار، فالمواجهة، والصراع حتمي، وبدون هذا الصراع لايكون هناك تقدم بل ضمور، وجمود، وتحجّر .هذه الرؤيا قريبة من رؤيا هيراقليطس التي عرضناها بشكل مختصر في بدايـة هذا البحث ـلقد طبق هيغل فكرة الصراع على عالم الطبيعة، فهو يوضتح تعــارض الأشـياء وصـر اعها فهنـاك لـون مـن ألـوان الحـرب هـو بمثابـة القـوة المحركـة لتصور

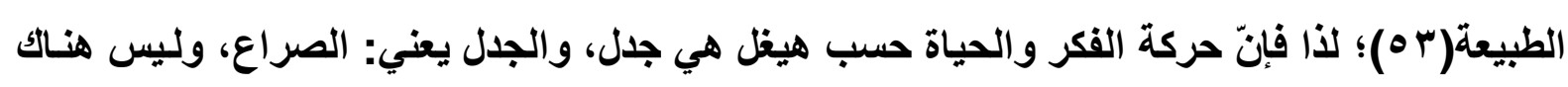

توقف في هذا الصراع.

ويرى هيغل من خلال مفهوم السلب الذي استخدمه كأداة في منهجـه أنّ في الحرب شيئـا ليس تجريبيا أو عرضيا بل تدخل الى مصاف " الفكرة الفلسفية التجريديـة" أي: إنّ فكرة الحرب" الصراع" تدخل في لبّ البنـاء الفلسفي الميتافيزيقي "الهيظلي" ( ع ه) ـويعطي ذلك دفعة قويـة لشرعية الحرب من خلال البرهنه على أنّ الصراع أمر لابدّ منـه، ومـن خـلال علاقة الدولـة مـع الفرد وعلاقة الدول مـع بعضها يقول هيغل:"في الوجـود التجريـدي نجـ أنّ العلاقـة السلبية تتجلى على شكل علاقـة آخر بآخر"اي: دولة بدولة أخرى" كما لو كان السلبي آمرا خارجياً ووجود هذه العلاقة السلبية يتخذ شكل حادث تثابك مع ظروف عرضية تاتي من الخارج لكنه في هذه حيث هي مثالية لكل مـا هو متنـاه فيها ـ والجاتب الذي فيه الجوهر من حيث هو قوة لامتتاهيه ضد كل مـاهو فردي، وجزئسي، وضد الحيـاة، وضد الملكية، وحقوقها وضد كل الدوائر الأخرى". (00) هكذا نرى أنّ أداة السلب بوصفها فكريـة وتجريبية تصل بالإنسان إلى مستوى وعي أعلى من حالة الطبيعة التي كان يعيش فيها لياخل في الكل الأخلاقي "الاولة".

إنّ للحرب قوة سلب كبيرة جداً، فهي سلب للمتنـاهى " الإنسان" وهي إيجاب الدولة وسلطتها سلب للأفراد؛ لأثّها تلغي حقوقهم، ومصالحهم، وملكيتهم، وحتى حياتهم، وينقلب السلب الى ايجـاب بالنسبة للاولة، إذّ الحرب تبرهن على السلطة المطلقة للاولة، وهذا السلب يضفي على القرد صفته الايجابية، ويعطيه طبيعته الفعلية؛ لأنّه يقتنع بالكل الأخلاقي، ويدخله تحت مظلة الدولة.

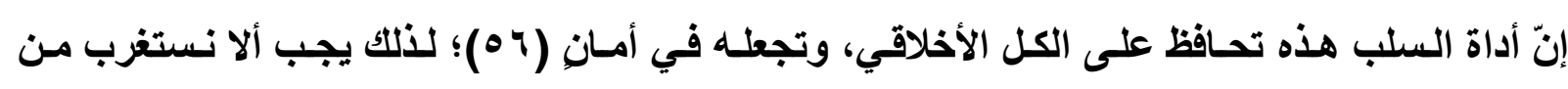
الموقف الهيغلي من الحرب، أو نعتبره موقفا شاذاً عن مجمل فلسفته، فموقفه من الحرب هو استتتاج طبيعي لقلسفته السياسية التي لاتنفصل عن البناء الشامل لنظامـه القلسفي، ان هيغل سوف" لايكون أمينـا على بنائـه القلسفي، وعلى مذهبه، ومنهجـه إذا عدّ الحرب مـثلاً ظـاهرة عـابرة، أو شـاذة، أو ظاهرة يمكن تلافيه أو أنّ السلام هو الأسـاس في الحيـاة، أو في طبيعة الإنسان أو هو الحالـة العقلية والأخلاقية كما يرى كاتت أنّ هيخل قارىع جيا للتاريخ الإنساني، وهو في الوقت نفسة فيلسوف أكثر 
إحساسـا بواقعه، حيث عاصر الحروب الطاحنـة التي حدثت في زمانهـ؛ ولذلك فِإنّ حلم السلام الذي تحدث عنه الفلاسفة و المصلحين قبل هيغل، وفي حياته يعّد حلمَاً غير واقعي، وبمـا يرى أنّ مـاهو واقعي معقول والفيلسوف لايجب أنْ يتخطى واقعه، وهيغل لايجنح الى الخيال، ولايتحدث عمّا ينبغي أنْ يكون بل هو يصف، وبواقعية شديلة مـاهو كائن، والحروب المستمرة والطاحنة نموذج لذلك؛ لذا كان من المعقول جداً أنْ يستتتج هيخل أنّ الحرب في طبيعة الإنسان - وأنّ الحرب ضرورية للاولة، وندان

$$
\text { وأثيّه ليس هنالك سلام دائم (هV). }
$$

حينما اراد هيخل ان ييرهن على معقولية الحرب وحتميتها، فهو لم يقصد بحرب الإنسان ككائن فرد خـارج نطاق المؤسسة التي ترعـاه الدولـة. إنّ الإنسان حسب هيخل هو كـائن جزئسي "متــاهي" وإذا مادخل الحرب لمصلحة فرديـة، أو منفعة عـابرة زمانيـة زائلـة سـوف لاتكون حربـاً ذا قيمـة، أو حربـاً أخلاقية، أو قانونية، لأنّ صر اعه سوف يكون لغاية فردية، وليس لغاية كليّة أخلاقية، أو لهدف نبيل،

$$
\text { وسوف تكون أشبه بصراع حيوانات لإشباع غرائزها. }
$$

لقد أوضح هيخل ذلك بثيء من الإسهاب حينمـا تحدث عن معارك، وبطولات أبطال العصور الوسطى، ومن قبلهم أبطال هوميروس في حروب طروادة، وأبطال الشعر العربي في العصر الجـاهلي، وابطال الغرب المسيحي في العصر الإقطاعي أمثال فرسان الطأولة المستديرة، وحلقة الأبطال حول شـارلمان (1 ه) ـإنّ هؤلاء الأبطال ليس لهم ارتباط وثيق الصلة بالدولة، إنّ روح هؤلاء ألابطال، وإحساسهم بالحرية الفردية"المجردة" لايمكن أنْ يسمح لهم بالاندماج بالدولة؛ ولذلك فإنّ شجاعتهم و إقدامهم على تحمـل الأهـوال، والصعوبات في الحرب ليست نابعـة مـن إحساسـهم بـوطنهم؛ لأنهم لايؤمنـون بالدولة كجوهر أخلاقي كلي يجب الانضواء تحت حمايتها، والايمسان بهـا بـل بعتبرون أنفسهم هـ الدولة، وهم فوق الدولة؛ لأنهم مؤسسّيها وحاميها، إنّ هؤلاء الأبطال لايشعرون بالتماهي مع الدولة، أو مع الملك الذي يمثل رمز الدولة إنّ الفرد البطولي لايقيم فاصلاً بين ذاته، وبين الكل الأخلاقي الذي هو جزء منـه بـل يعتبر نفسه يؤلـف هذا الكل الأخلاقي وحدة جوهريـة إنّ هؤلاء كمـا يـرى هيغل لايتبعون سوى اهوائهم فاغامنون كان محاطا بالأبطال الأحرار الذين لاسلطان لـه عليهم بـل كان يأخذ بمشورتهم في كل مناسبة ونرى رغم ذلك أنذهم يهجرونه وهو في منتصف الطريق(ه ه ) إدّ يسعى كل

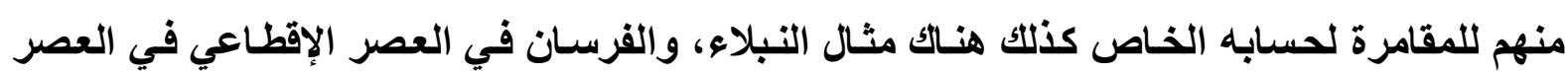
الوسيط وبدايات العصر الحديث فرغم ارتباطهم بملكهم، ولكن الآصرة التي تربطهم بالملك تتعسارض

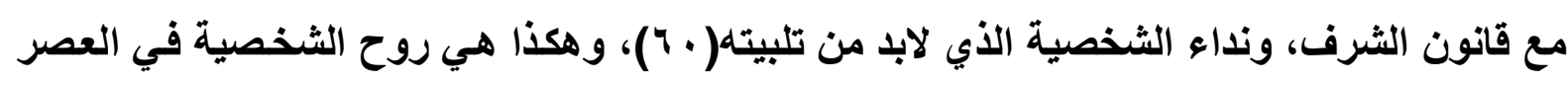
البطولي إنها روح لاتثعر بالانتماء للوطن، إنّها روح أكثر استقلالية عن القانون، والواجب الوطني هي غير داخلة في الكليّ أي غير واعيـة بالقانون العام لذلك، فـانّ هيخل يجد مـن الصعب الاعتمـاد 
عليهم في أزمنة الحرب، وحربهم لاتكرّس دخولهم، ووعيهم بالدولة شعور هم بفردانيتهم، وإحساسهم

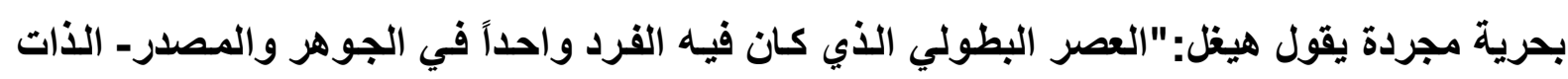

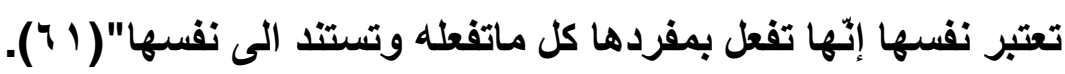

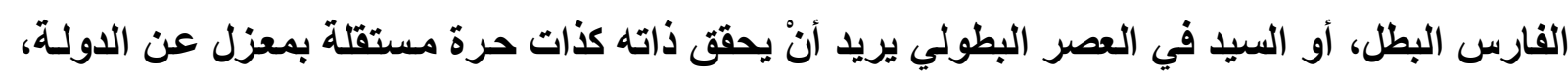

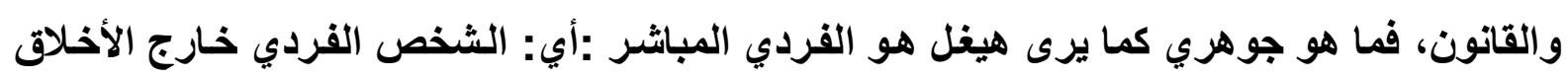
الموضوعية. إنّ الحرب هنا لاتزيد هذا الفارس البطل"|لفرد" إلاً تفرّدا وابتعادا عن الآدماج في الدولة، وبالتالي فِانّ

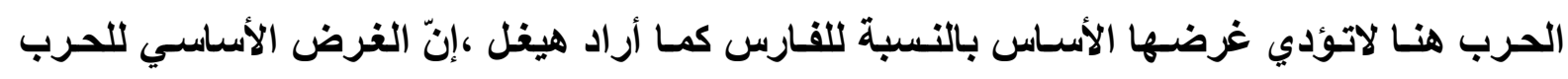

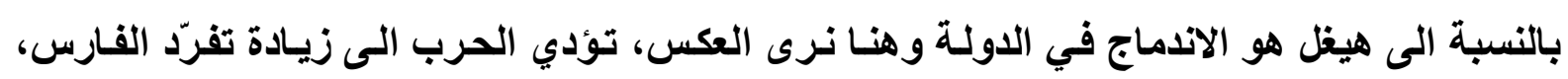

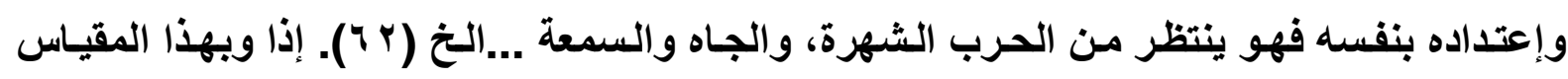

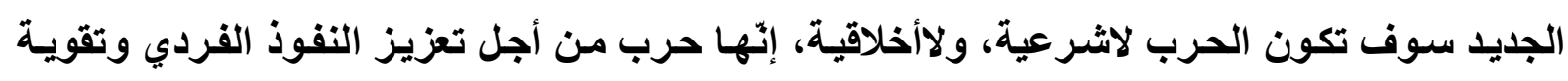

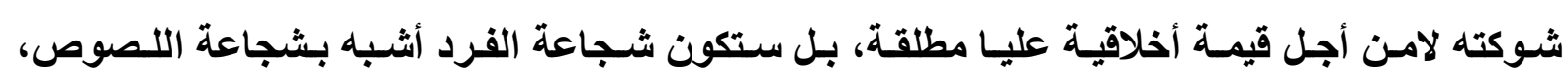

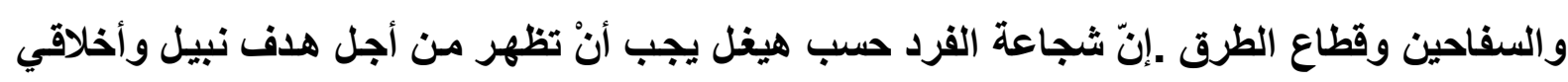

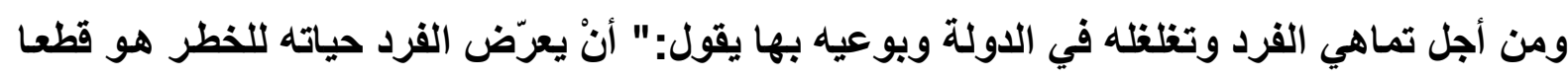

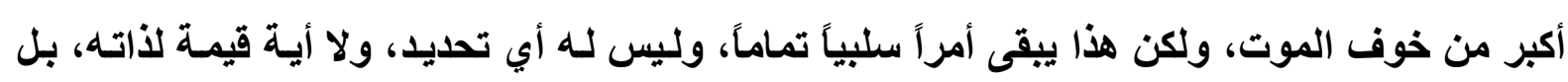

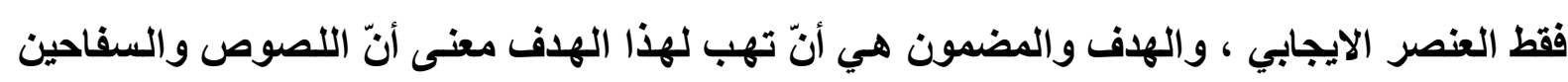

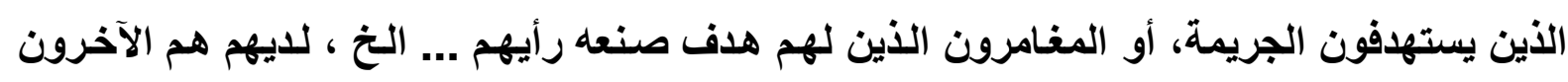
شجاعة تعريض حياتهم للموت..."( آ").

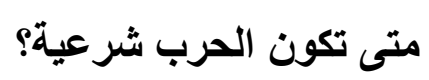

يرى هيغل أنّ" الحرب ليست حرب أسر ضد أسر أخرى بل حرب شعوب ضد شـ شعوب أخرى لقد تحول

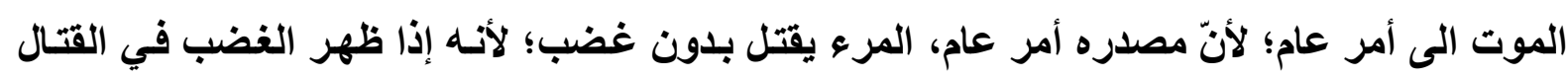

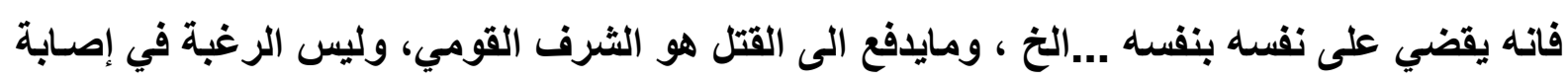

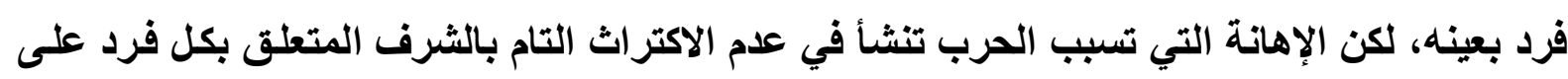

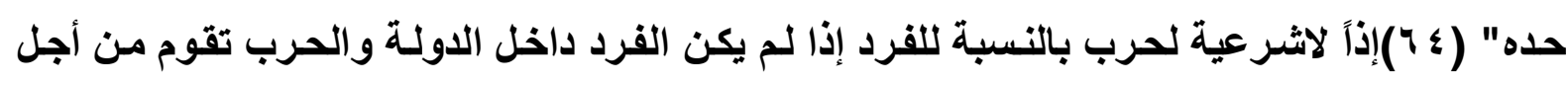

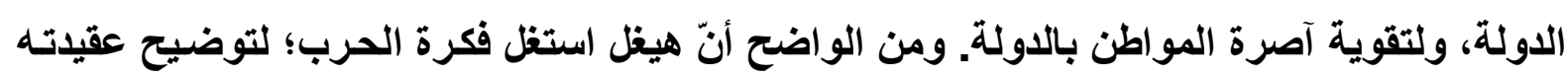

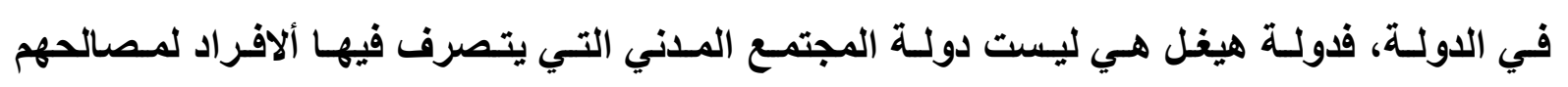

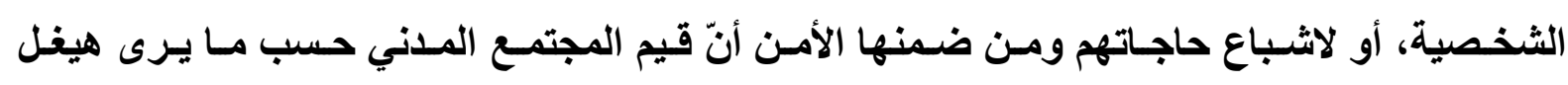

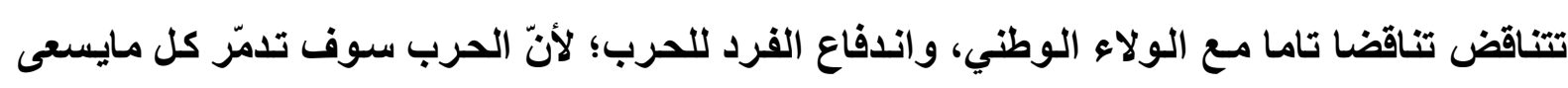

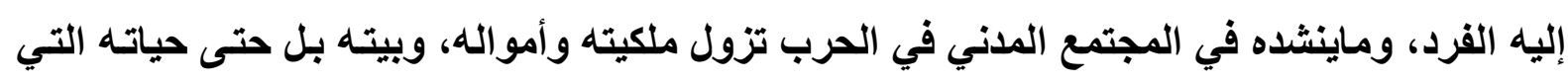


يسعى بشدة للحفاظ عليها، فالحرب كما يرى هيغل هي برهان حاسم على أنّ قيم المجتمع المدني، هي

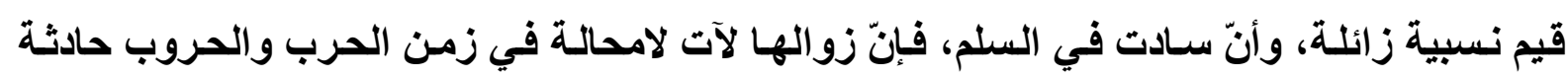

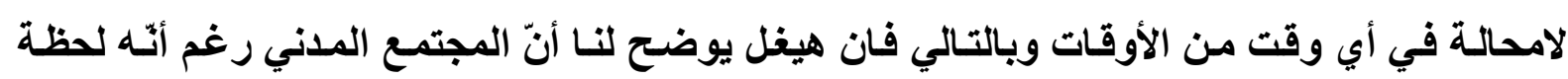

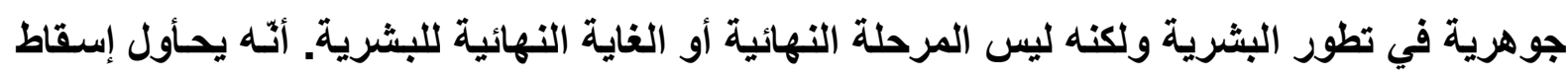

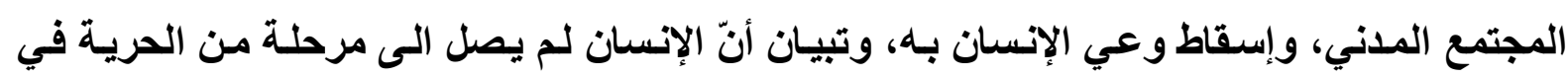

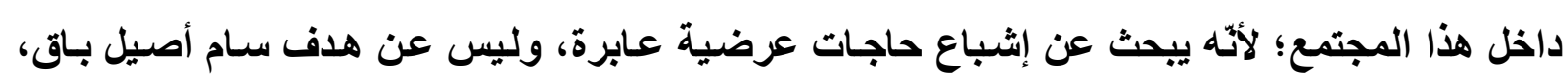

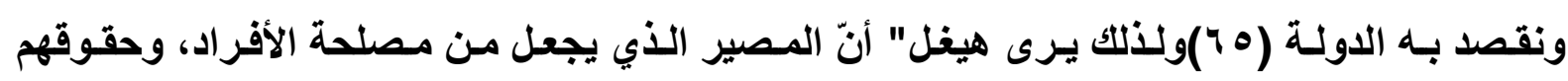

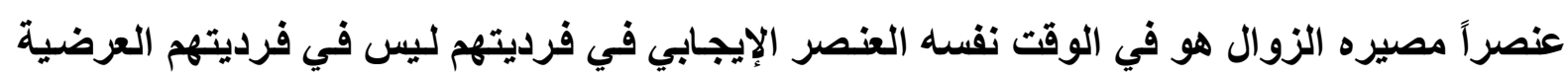

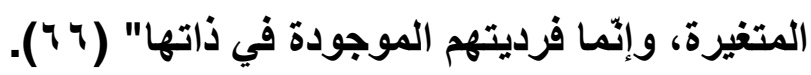

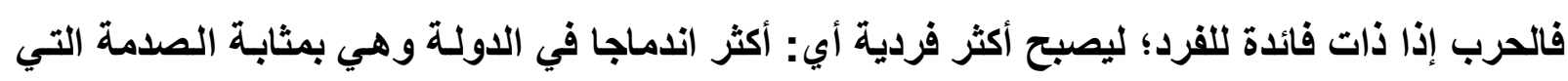

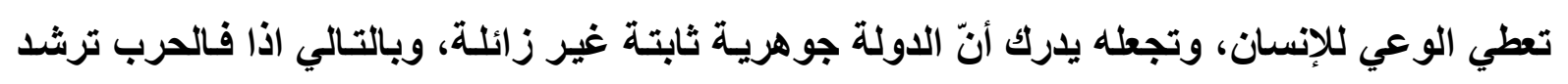

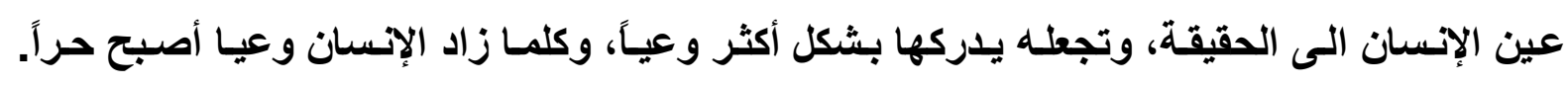

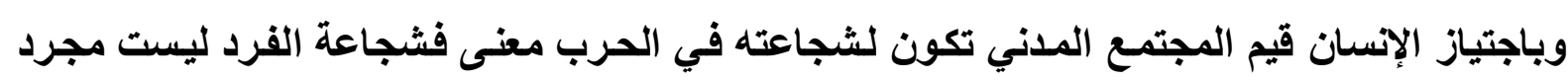

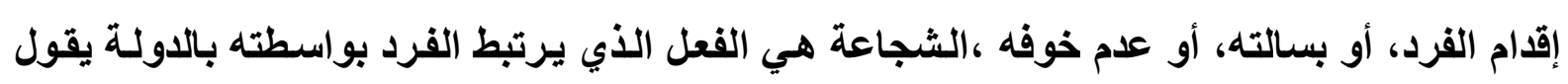
هيغل:القيمة الفعلية للشجاعة من حيث هي استعداد نفسي تقوم في الهـف النهائي، الحق، المطلق،

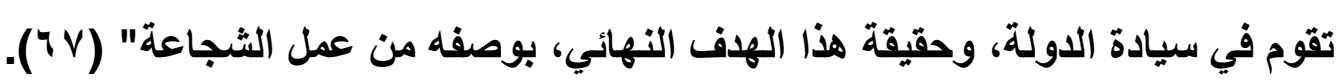

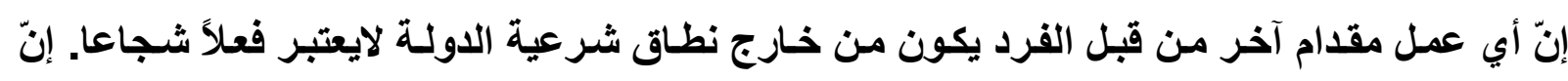

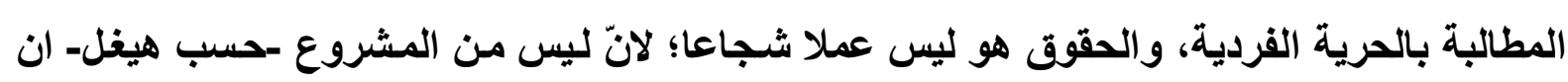

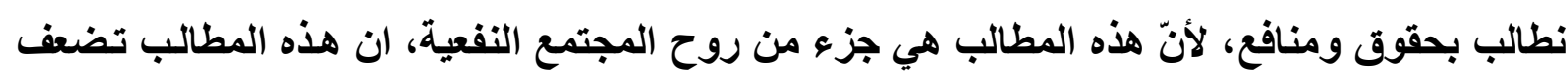

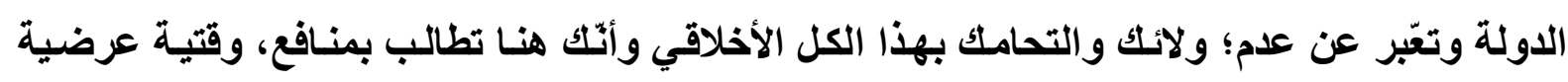

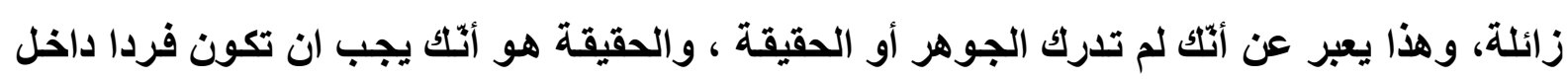

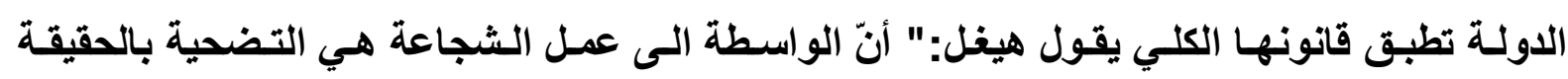

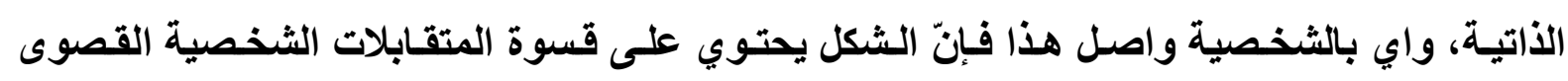

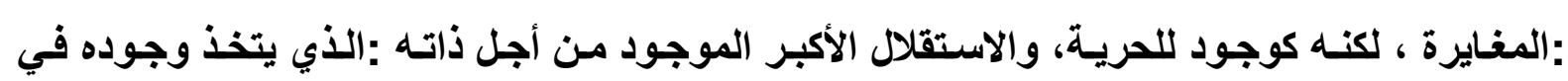

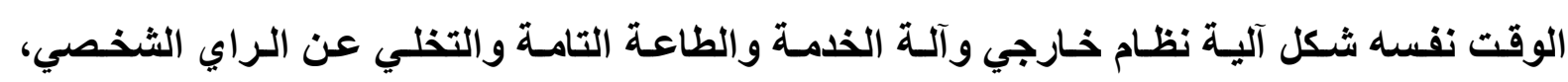

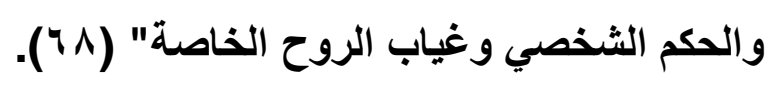

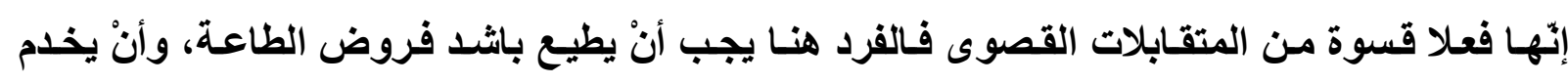

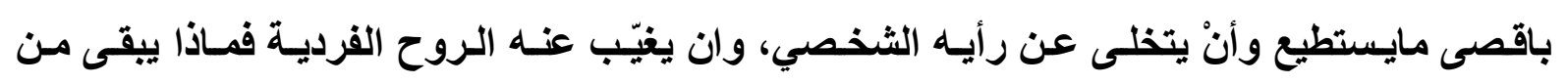

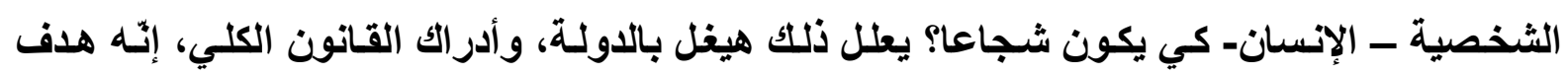


نبيل، فالدولـة هـي أكبر وأرقى، وأنبل، وأكثر شرفاً، وأكثر جوهريـة، وأقل عرضية مـن الإنسان،

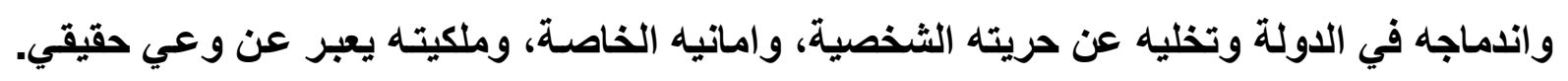

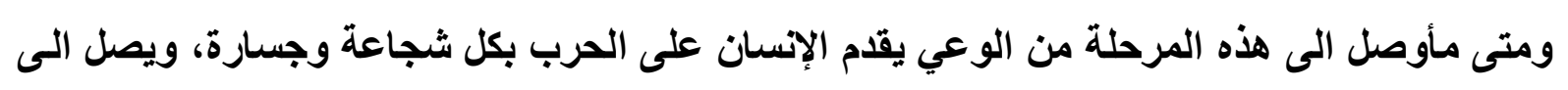

العقلانية الحقيقية.

إنّ ذوبان الثخص بهذا الكل وتخليه عن الأمور الثخصية كافة من الصعوبة بمكان بحيث يتطلب حسب الثب

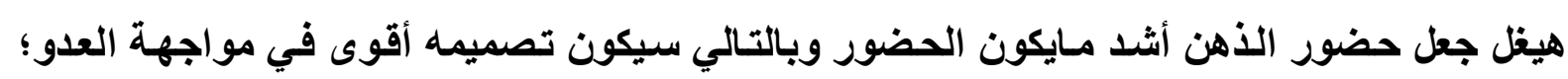

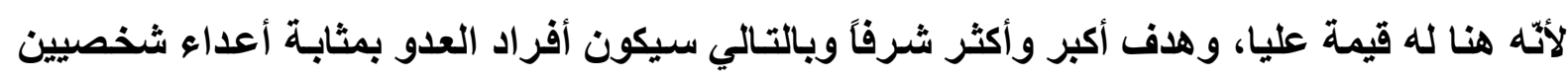

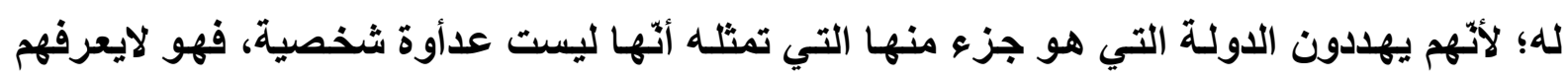

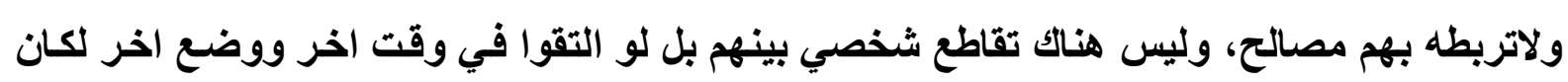

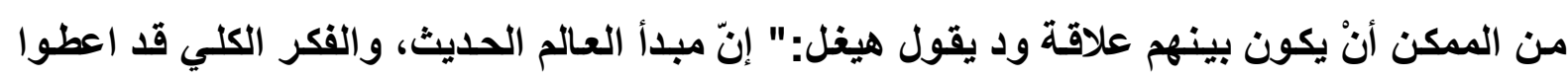

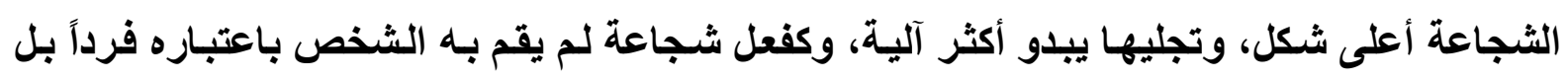

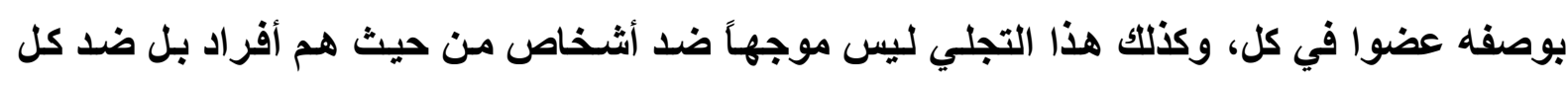

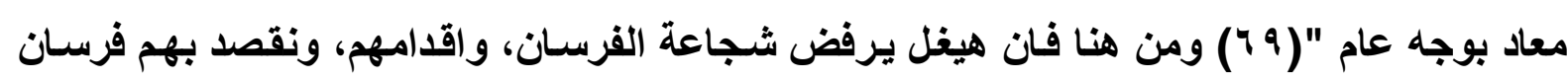

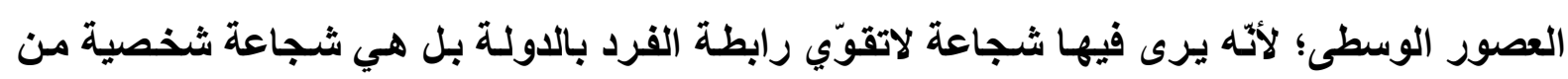

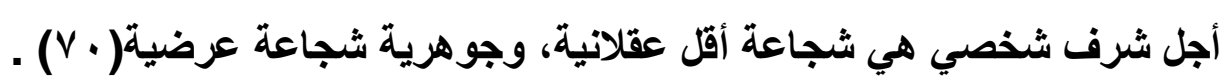

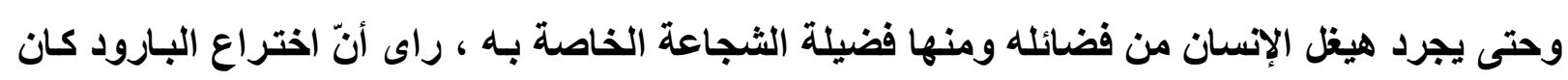

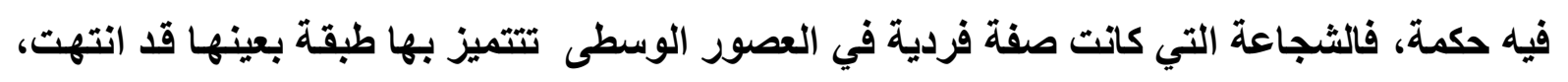

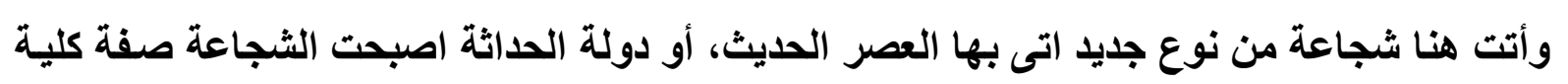
يقول هيغل:" السلاح الناري قد بّدل الوجه الثخصي للثجاعة وحوله الى وجله أكثر تجريداً (VIV)".

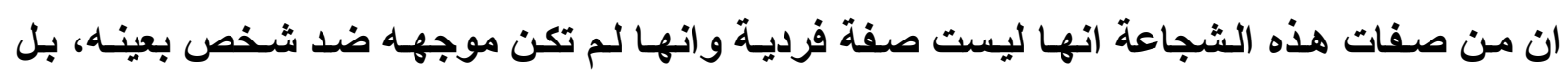

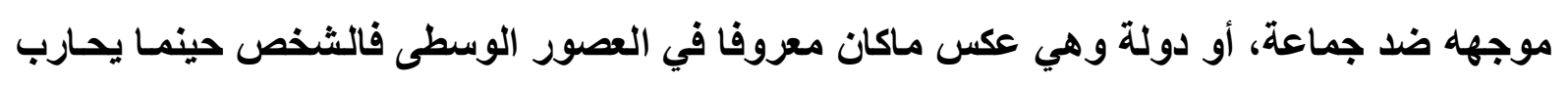

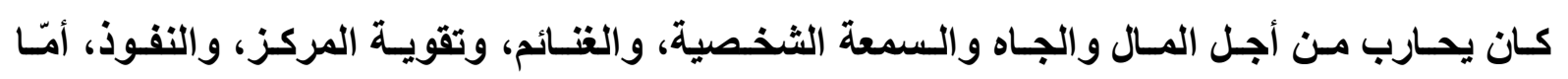

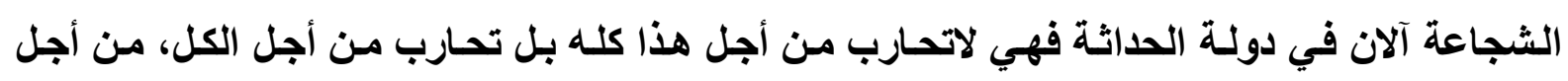

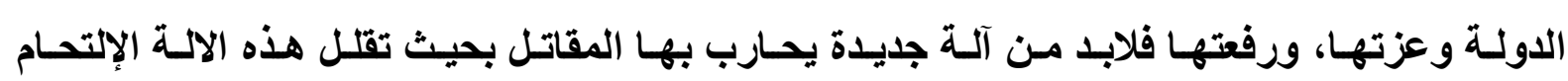

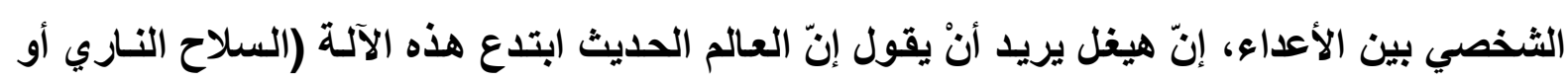

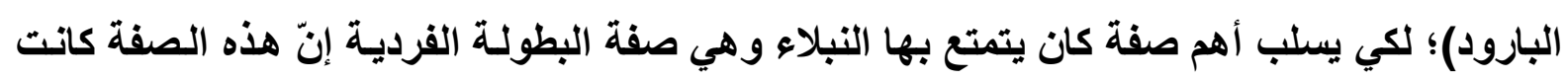

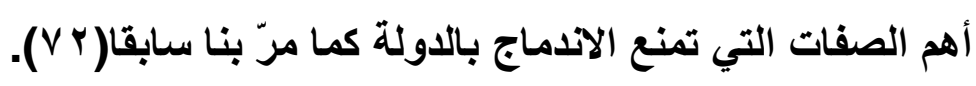

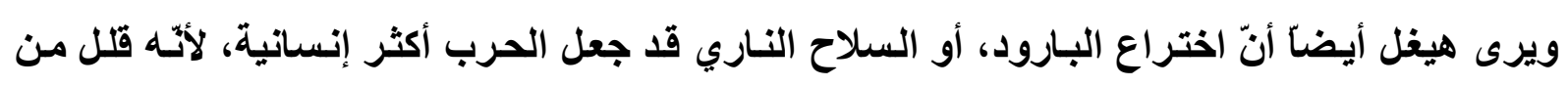

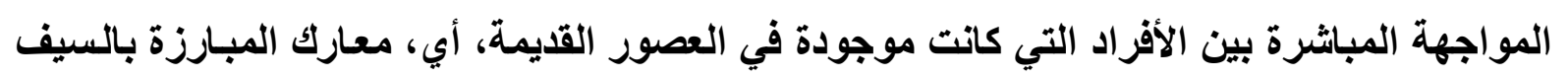


حيث تكون المواجهة مباشرة، وقريبة جدا، فالجندي الذي يطلق الرصاص، لايعرف الأفراد، ولايتواجد

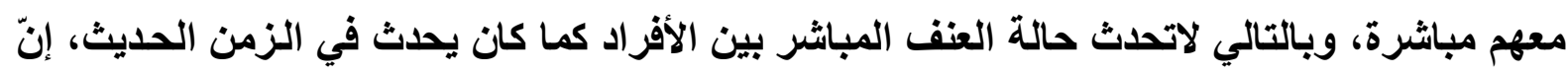

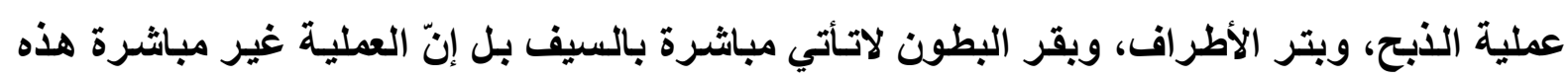

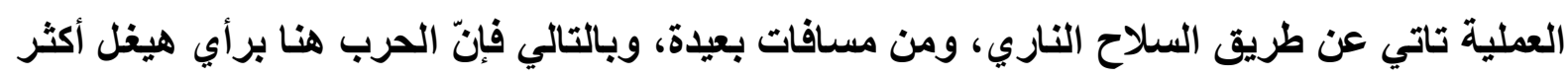

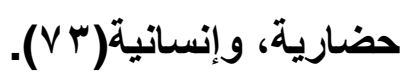

وفي الحقيقة إنّ اختراع البارود، والسلاح النـاري قدا أدّى الى فتلك، وقتل، ودمـار أكثر للبشرية، وإنّ

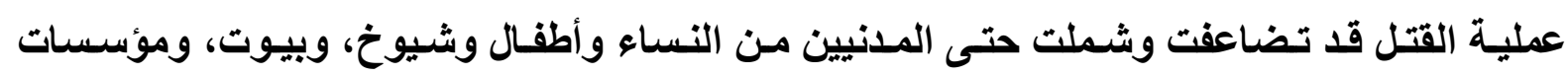

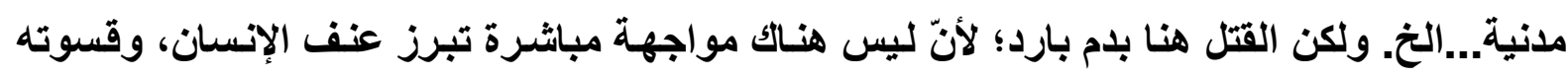

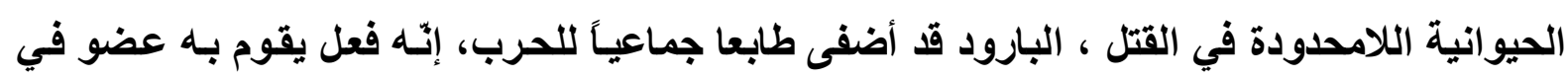

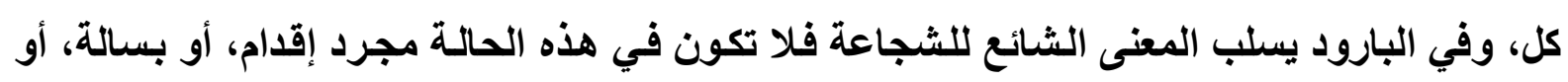

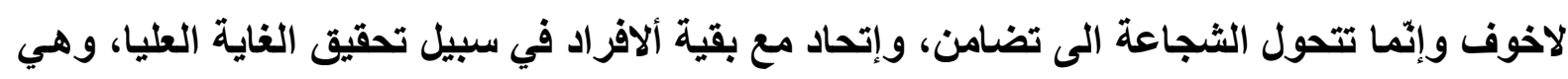

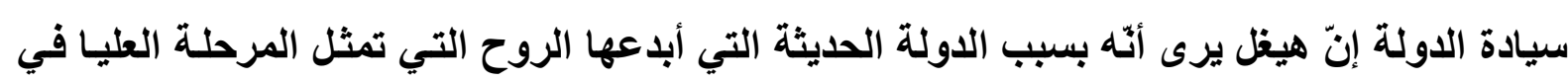

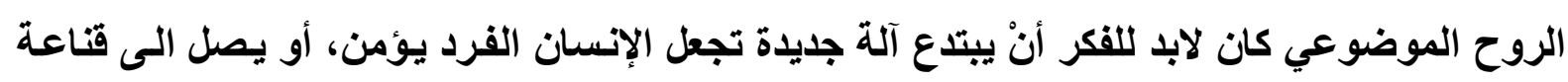

$$
\text { الحرب وضرون فرديته لاتسأوي شيئًاً( \& V). }
$$

إنّ الحرب تكثف عن نسبية الوجود البشري، وضـآلة حجم البشر إدّ إنّ الحرب مثل الكوارث الطبيعية

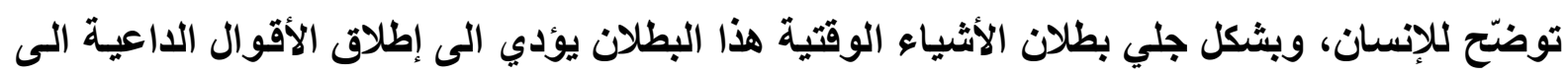

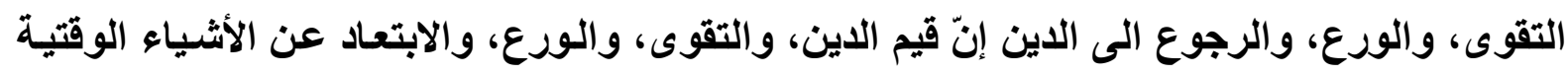

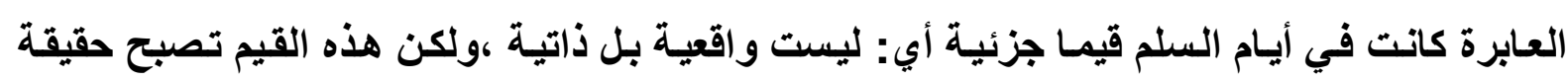

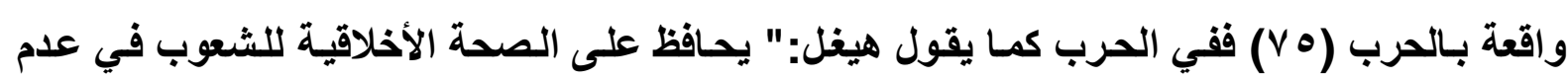

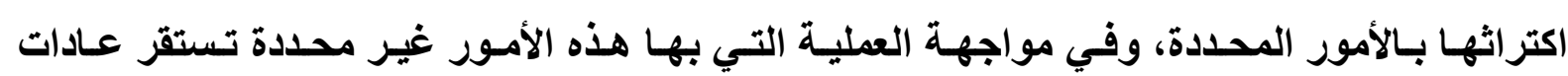
وتصبح ثابتة مثلمـا أنّ حركة الريـاح تحافظ على المياه في البحيرات من خطر التعفن التي يصيبها

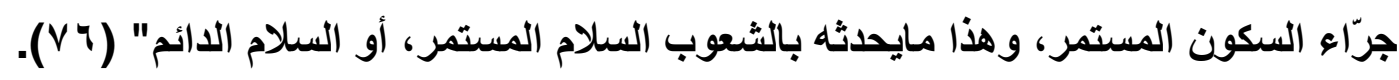

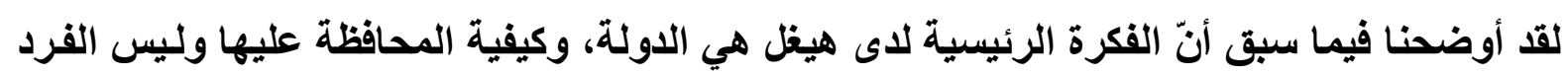

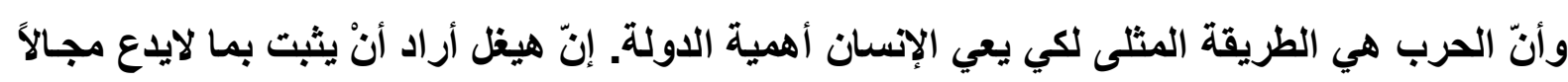

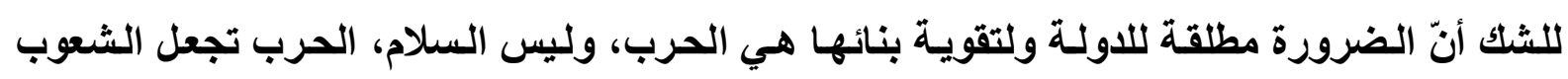

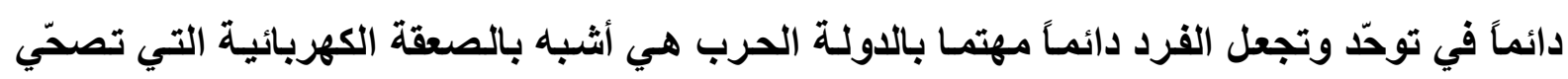

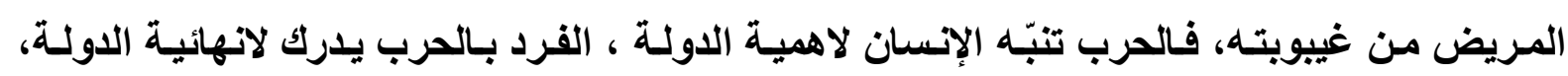

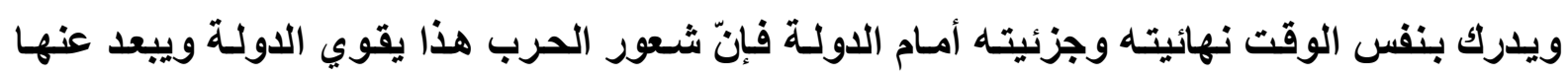


الانحلال كما أراد هيغل أنْ يجعل شعور الحرب هذا شعورأ مستمرأ لدى الدولة وإنْ لم تكن هنـاك حرب

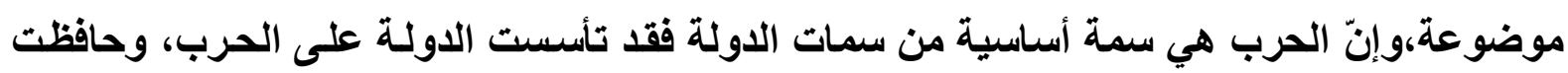

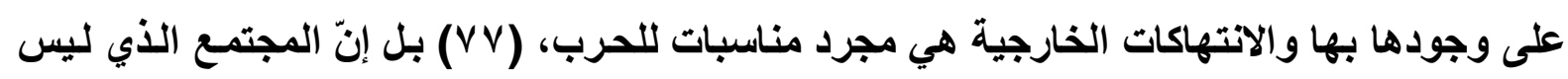

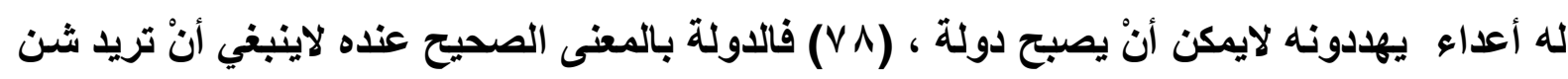

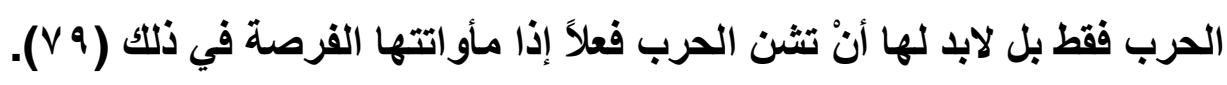

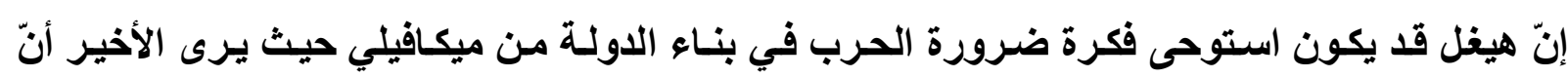

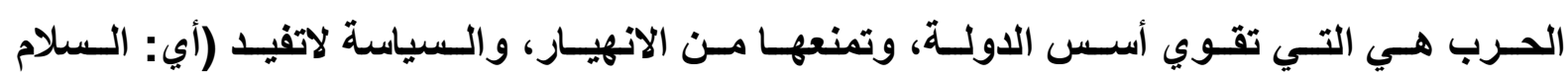

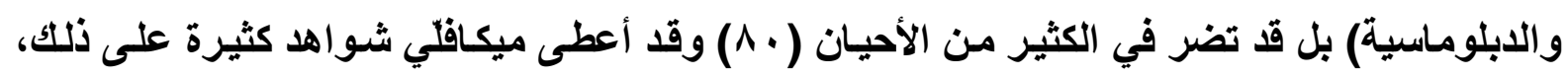

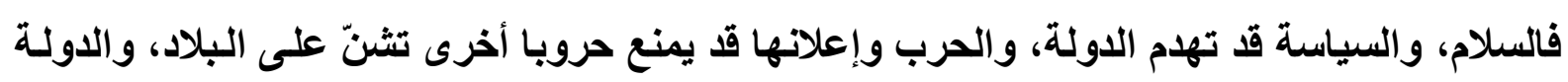

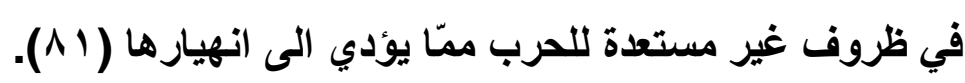

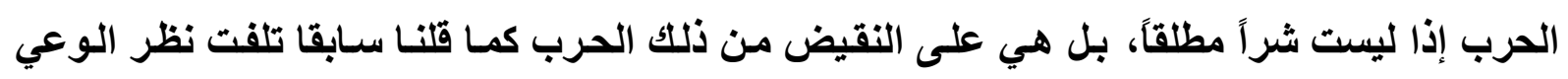
الفردي الى الثيء الجوهري الحقيقي، والضروري الذي يجب أنْ نسعى إليه، فبدون الحرب لابن لايمكن

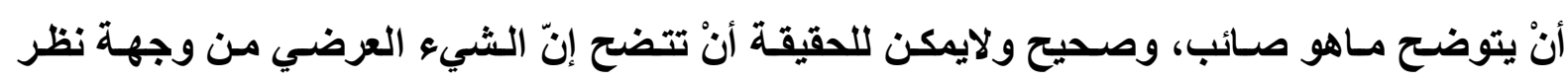

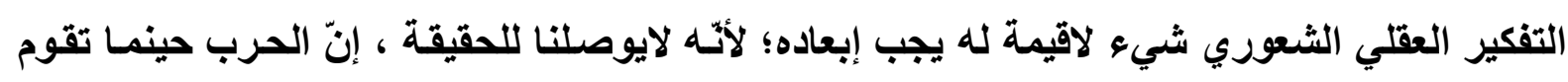

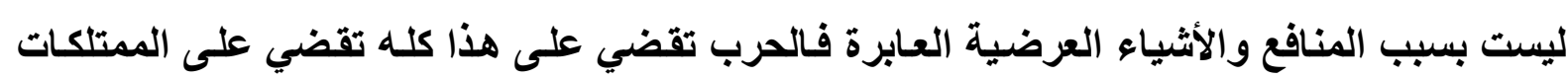
والمنافع بل حتى على نفس الإنسان، إنّ ضرورة الحرب، وغايتها هو : أنْ يتبين إنّ كلَّ شيء زلئ زائل،

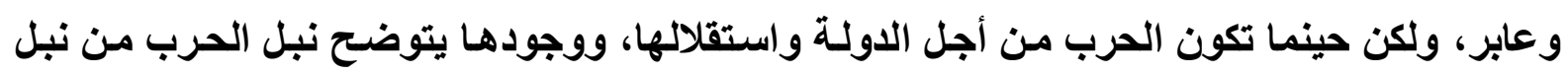

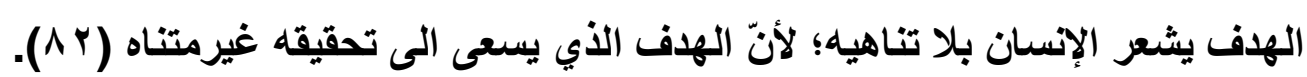

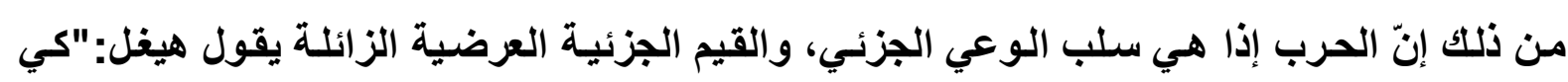

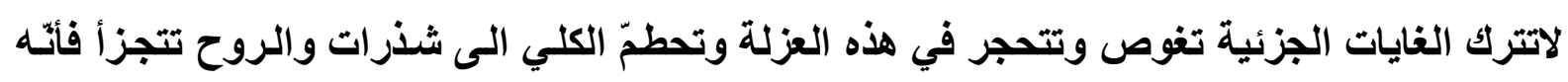

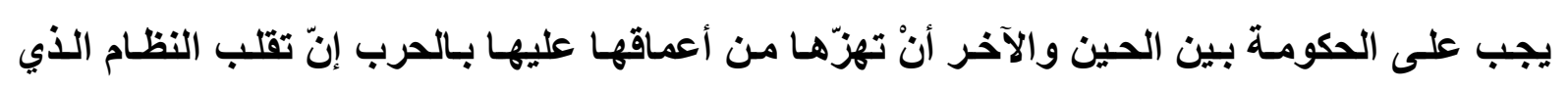
يصبح عاديا وأنْ تنتهك حقها في الاستقلال" (r (^).

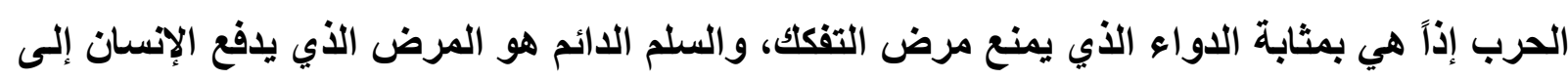

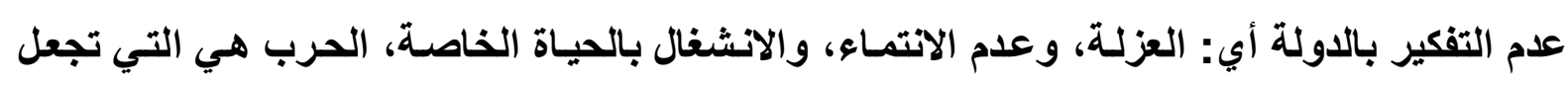

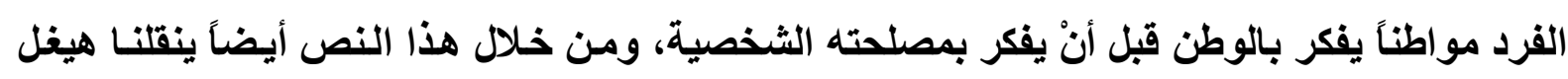

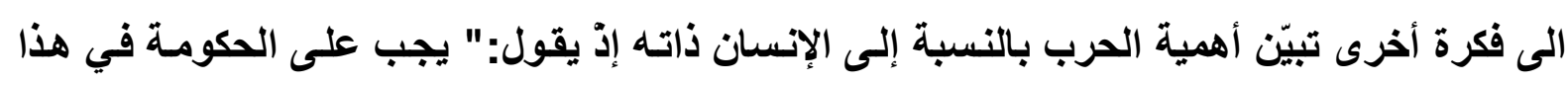

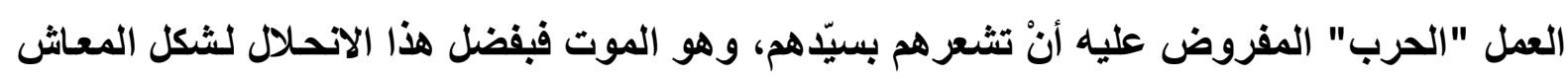

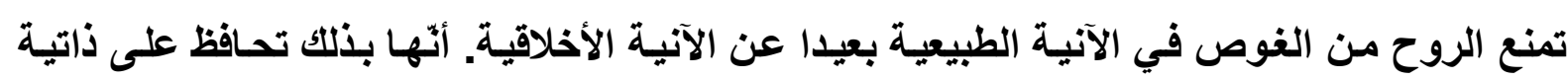

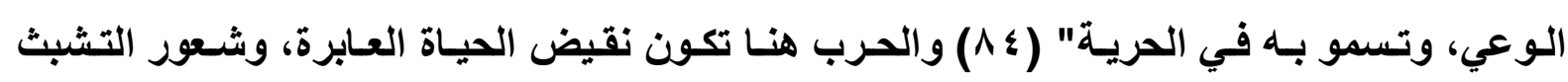


بالحياة، يجعل الإنسان عبداً لهذه المنافع بل تجعله أقل شجاعة؛ لأتّه متشبّثَ بالحياة، وبالتالي سوف

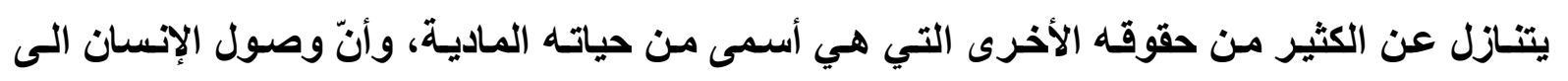

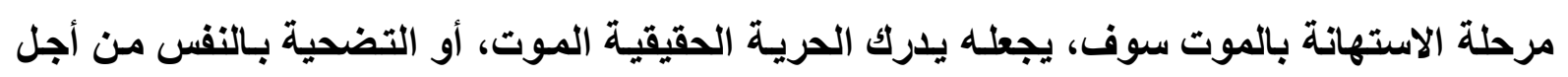

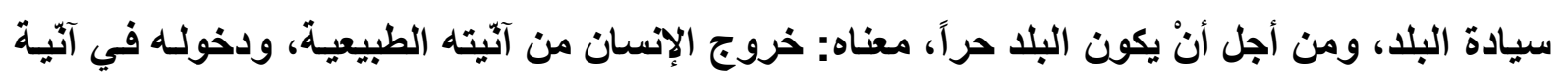

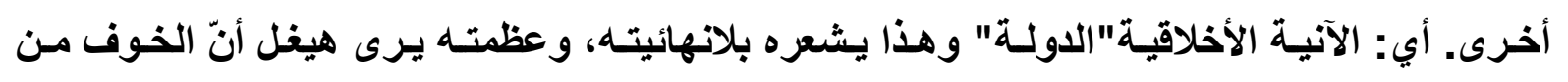

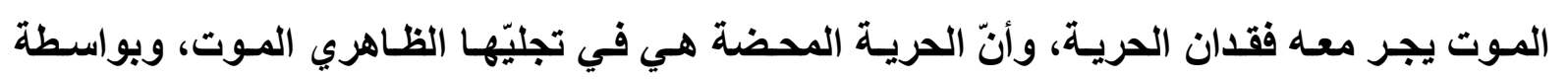

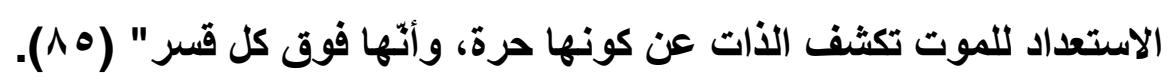

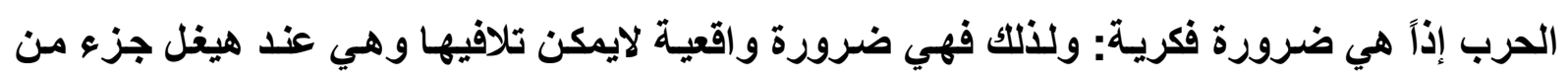

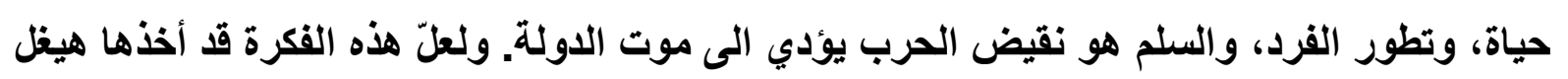

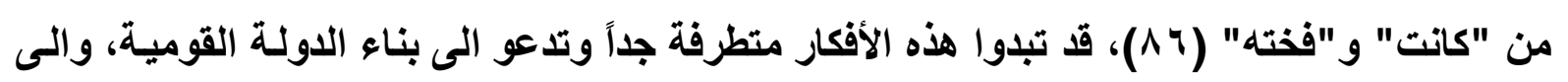
سلطة مركزيـة قويـة على حساب حريـة الفرد فالإنسان في نظام هيغل جزئيسة عرضية يحسأول دائمسا

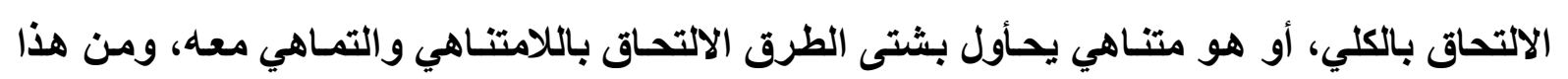

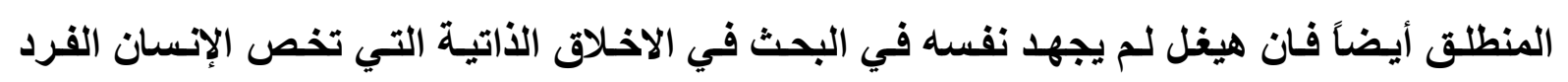

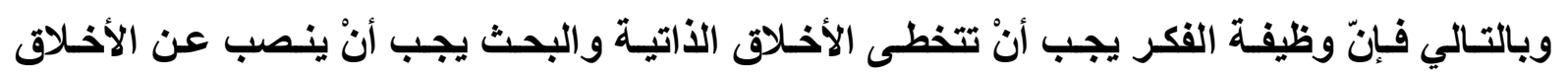

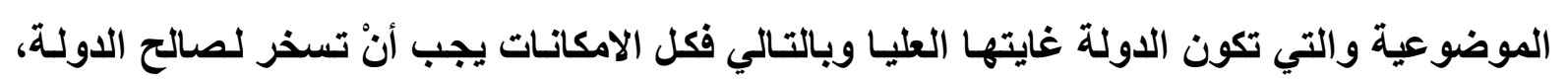

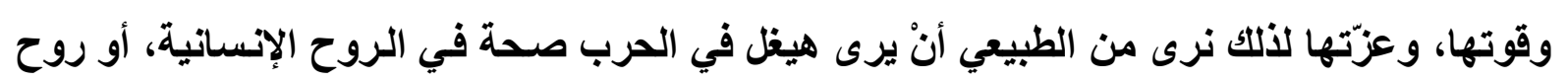

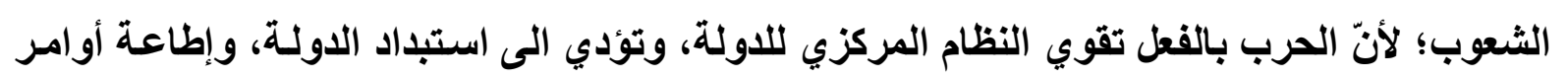

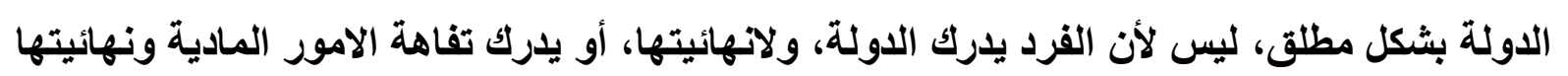

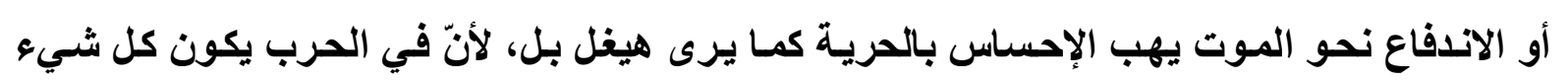

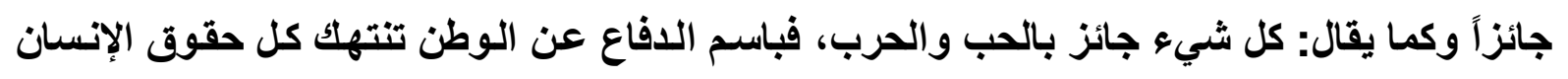

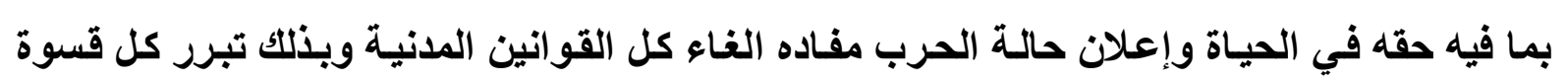
وتبرر الاعدامات المدنيـة، وتحل المحاكم العسكرية محل المحسكم المدنيـة، والأحكام العرفيـة مكسان

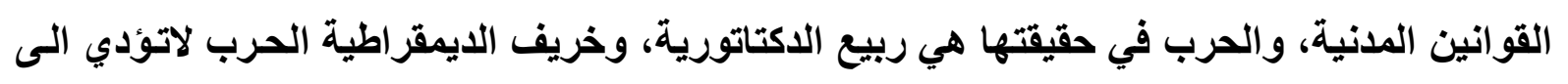

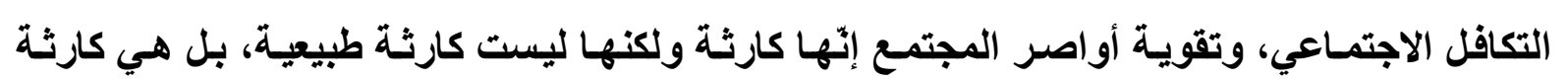

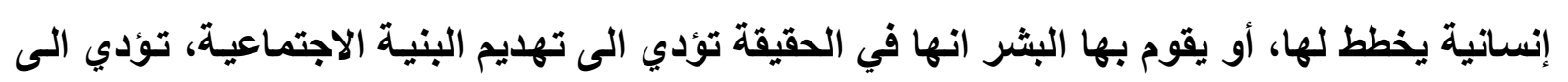

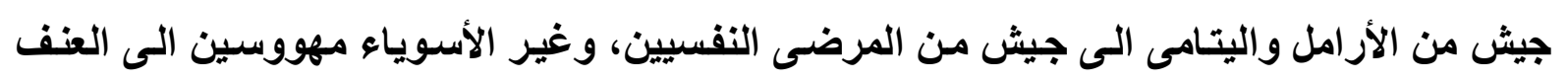

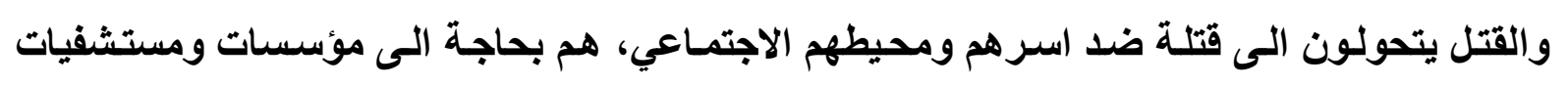
صحية، ونفسية خاصة كي تؤهّلهم مرة أخرى الى الاندماج في المجتمع و والعائلة. 
إذاً فما السبب الذي دفع هيخل أنْ يصّور الحرب بهذا الشكل الإنساني أو أنّها تحمل قيمـا أخلاقية عليا،

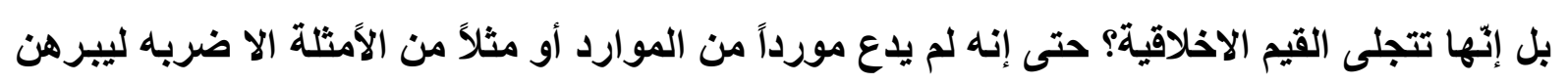

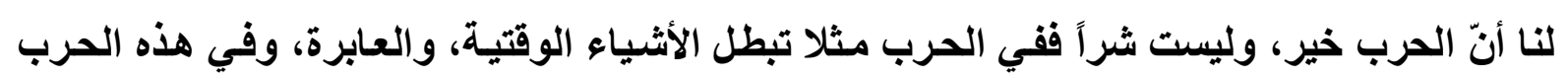

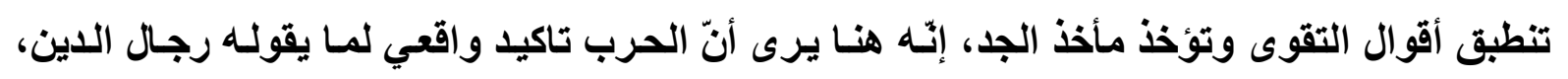

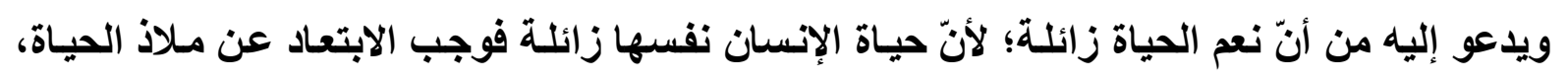

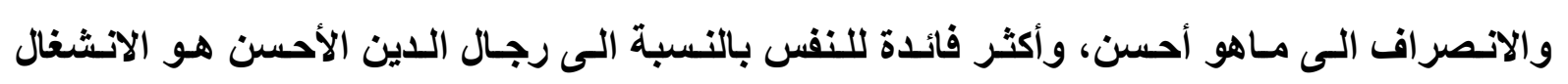

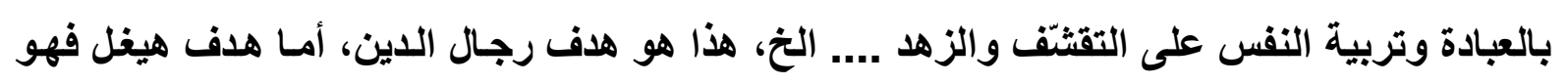

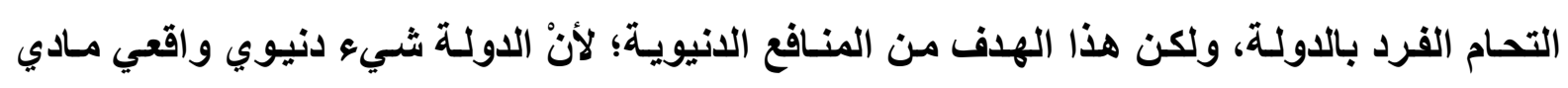

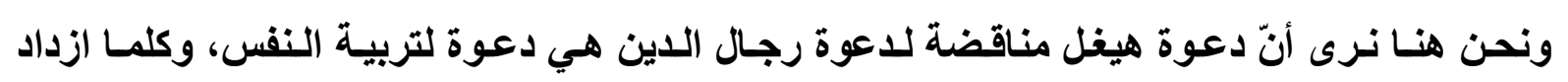

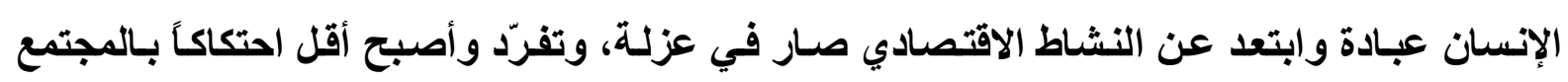

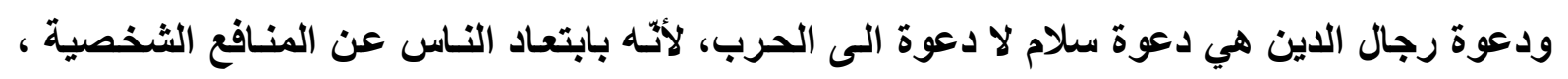

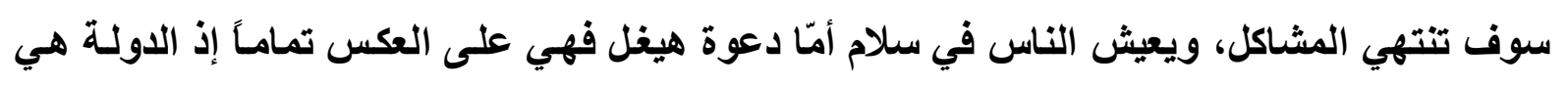

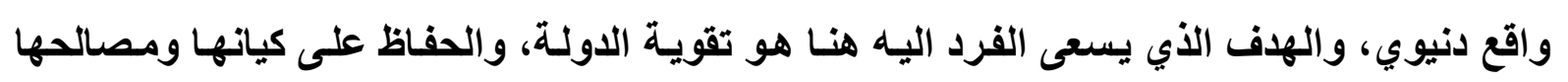

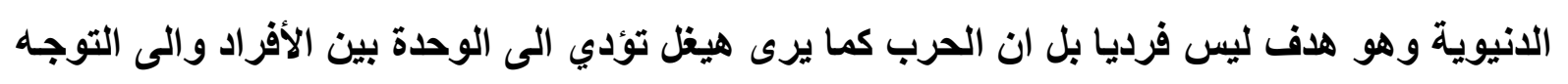

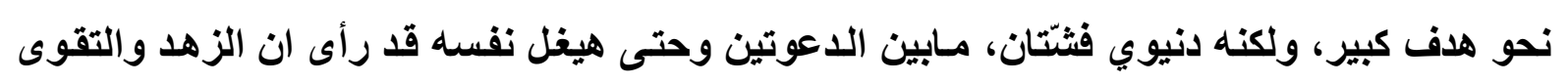

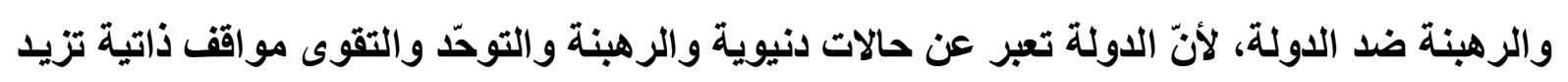

$$
\text { الإنسان والفرد عزلة (^v). }
$$

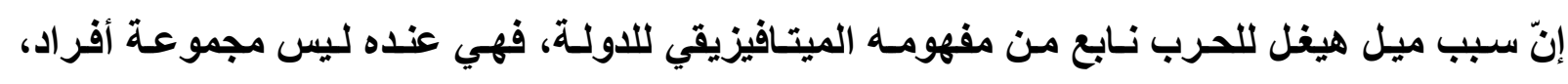

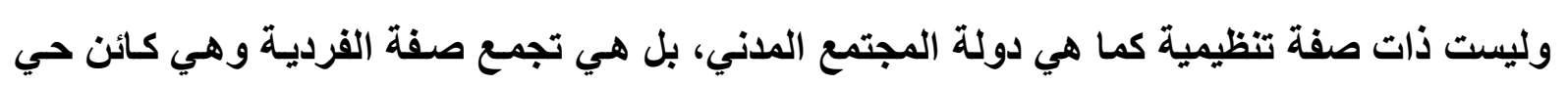

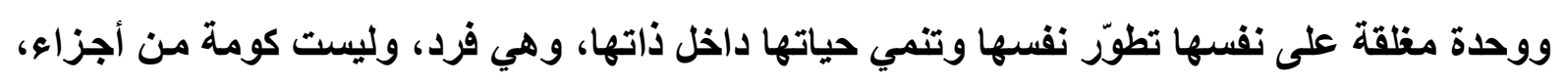

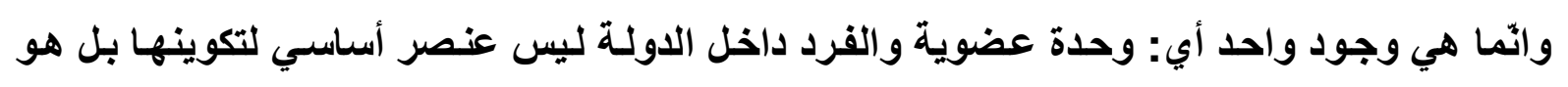

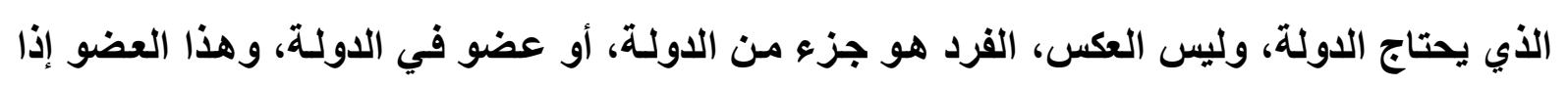

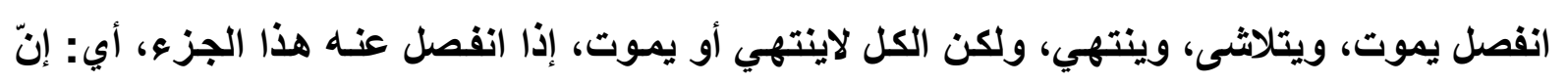

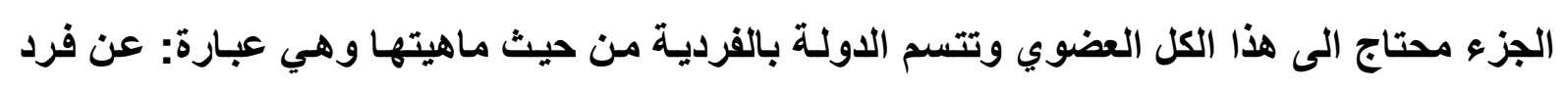

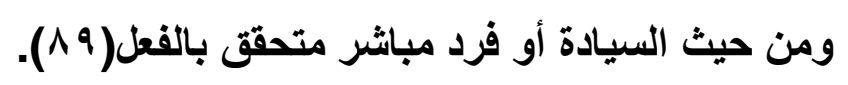

الأميز وقرار الحرب 
الدولـة حسب هيغل ثُلاث سلطات هي السلطة التشريعية، والسلطة التفيذيـة، والملك أمّا السلطة القضائية فقد دمجها هيغل بالسلطة التفيذية، السلطة التشريعية تمثل الكليّ، والسلطة التنفيذية تمثل فئل

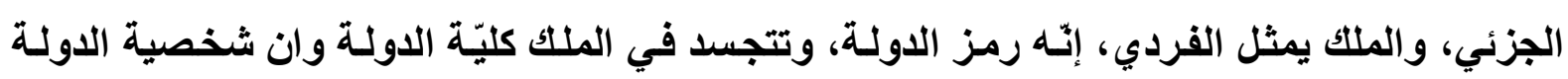

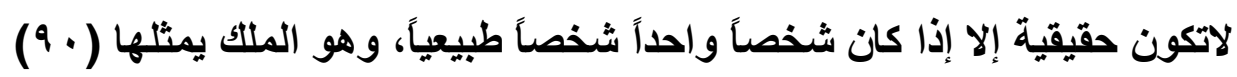

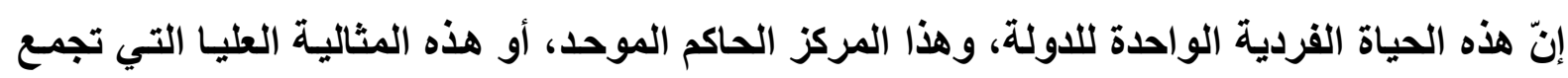

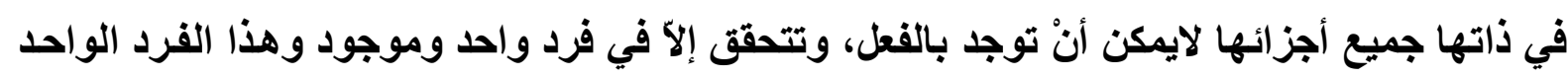

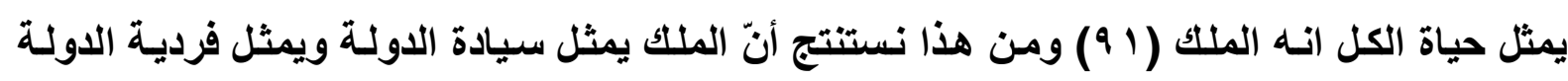

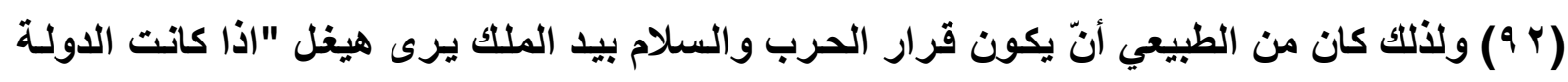

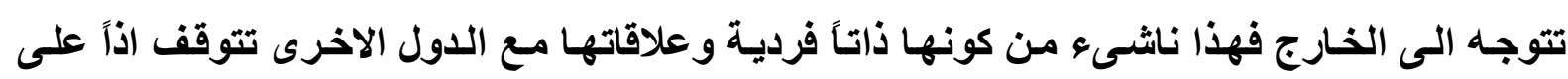

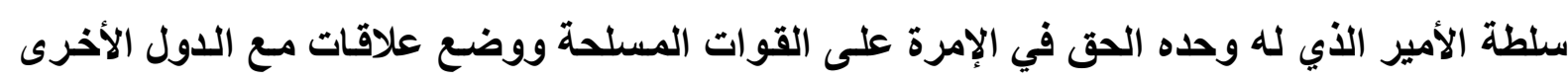
بواسطة السفراء واصدار قرار الحرب وعقد السلام" (ب 9) إنّ هيغل يدعو الى سلطة ملكية مطلقة الاهية

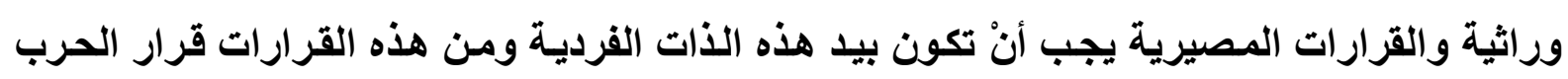

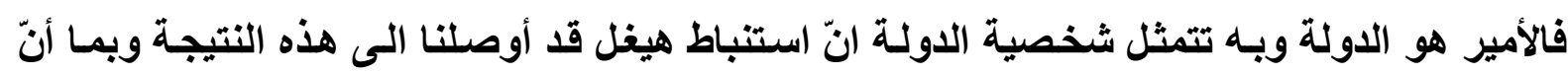

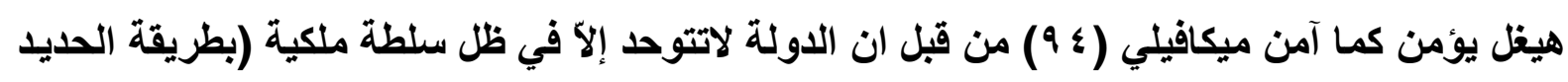

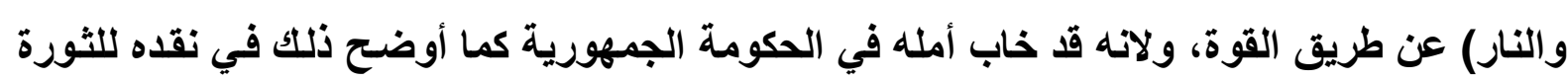

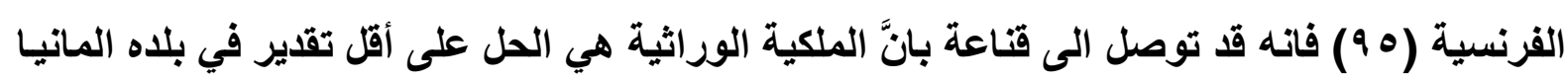

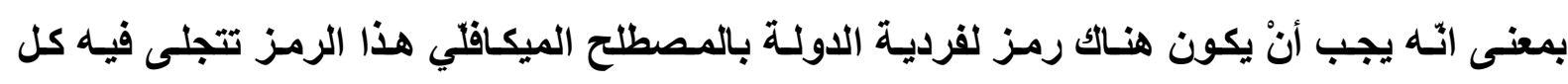

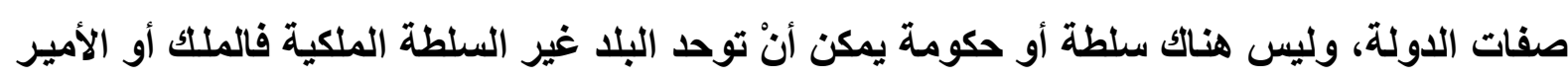

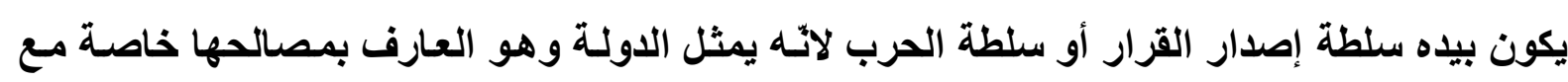

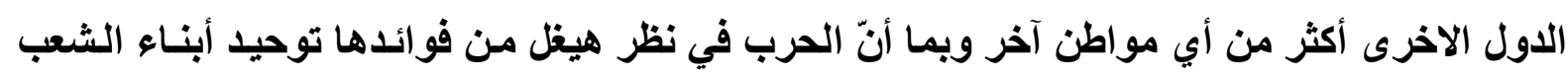

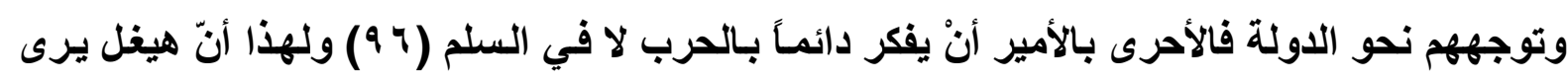

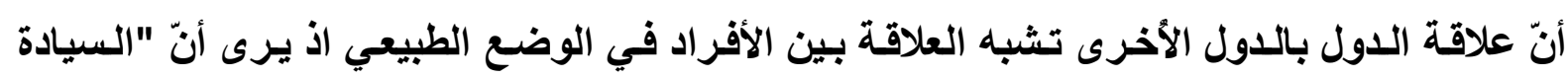

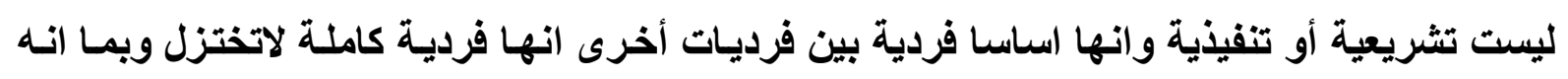
لايمكن أنْ تكون بين الافراد سوى روبط مباشرة طالما لم تتكون أي وحدة عليا فانسه لأوجود لقوانين

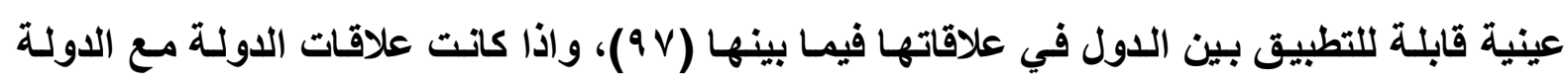

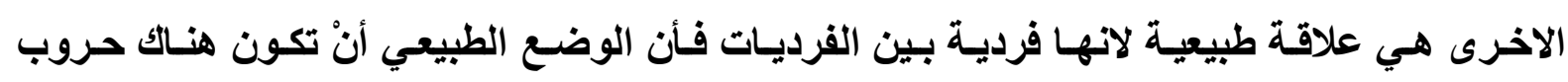

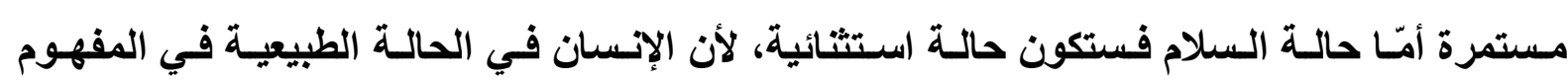

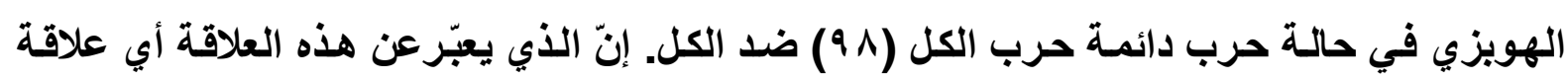

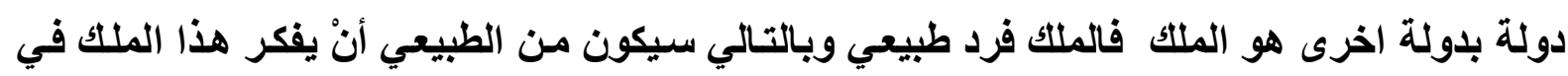


مصلحته التي هي مصلحة الدولة ومنفعته وهنا يبدأ تضارب المصالح بين الدول يؤدي هذا الى حالة

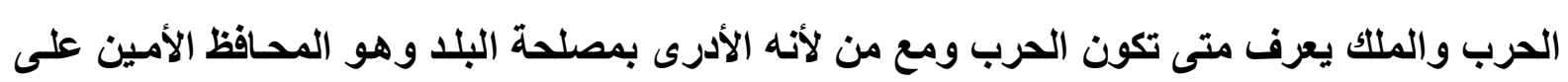
سيادته لانه الدولة. إنّ الدولة الملكية تكون أكثر استعداداً للحرب والأقدر على خوضها من الدولة ذات النظام الجمهوري

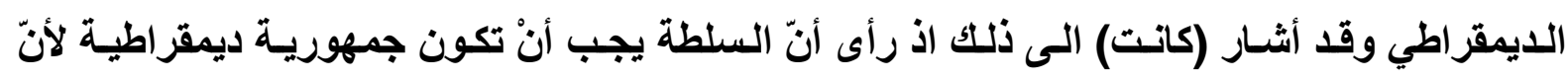

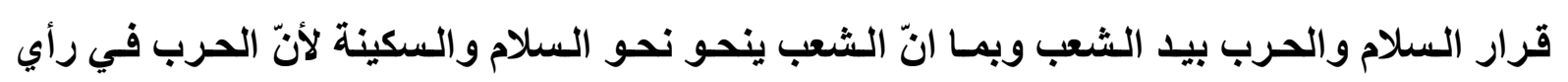

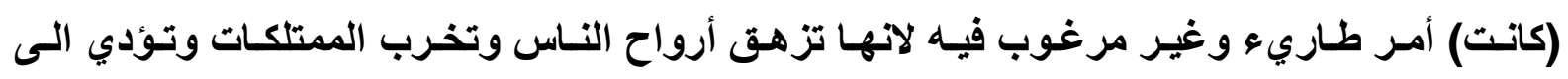

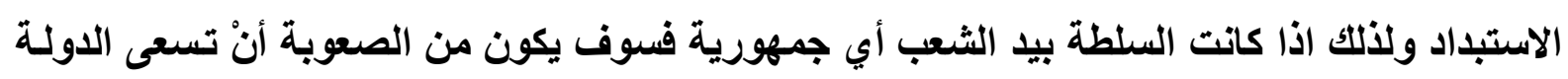

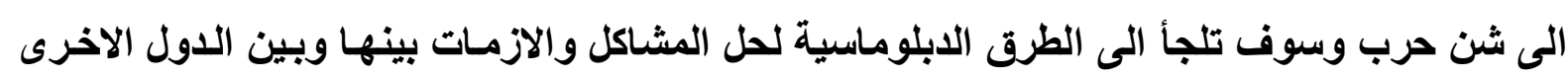
وتتجنب قدر الامكان القيام بالحرب. الا أنّ هيغل يرى عكس ذلك، اذ أنَّ الأمير في معظم البلدان الأوربية هو الرأس الفردي للاولة ولئه وعليه

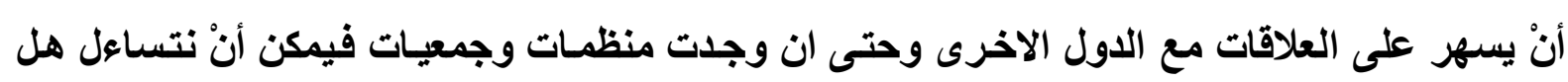
هذه الجمعيات هي التي ينبغي أنْ تقرر الحرب والسلام ويكون لها دور في هذه القان القضية لأنها هي التي

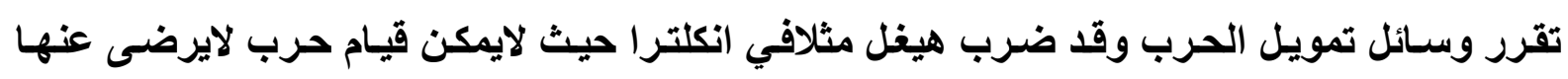
الثعب وراى البعض أنّ الامراء والوزراء أسهل خضوعاً للانفعالات من الجمعيات النيابية (البرلمـان)

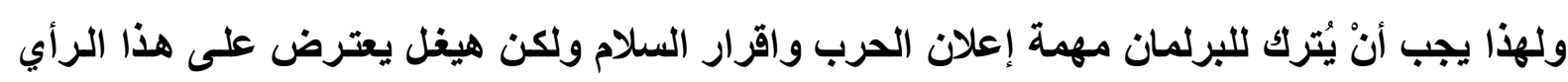

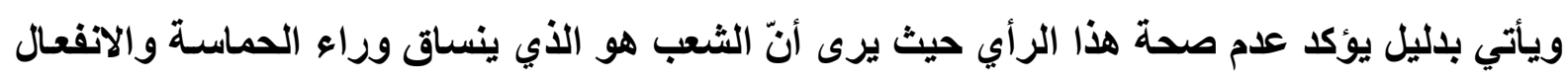

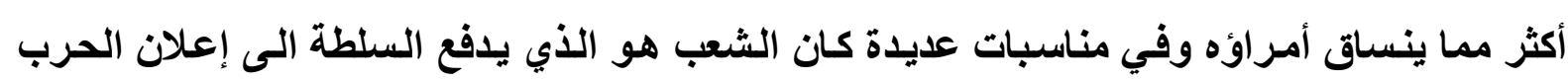

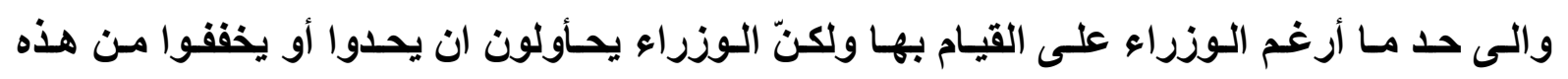

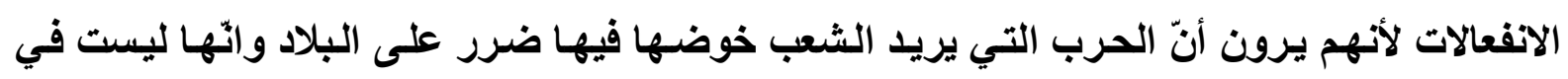

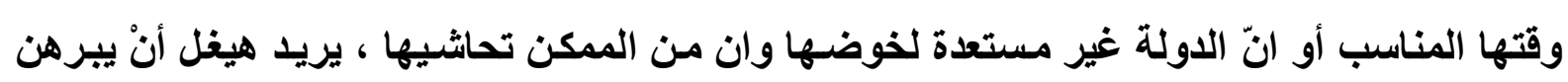

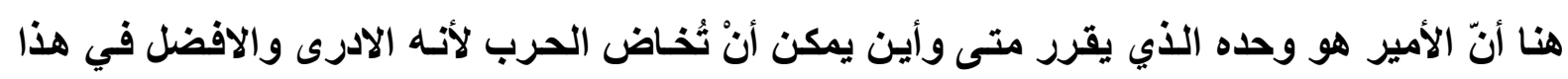

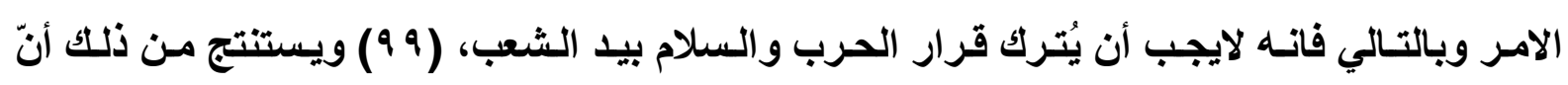

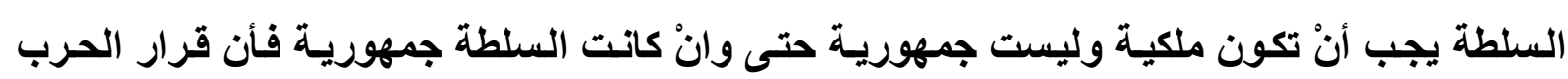
يمكن أن يتخذ وان السلطة الجمهورية لاتحد من الحروب بل قد يكون العكس. تبدو الرؤيتان الكانتية والهيغلية متضادتين والتضاد هنا بسبب الاختلاف في المنطلقات (فكانت) يريد

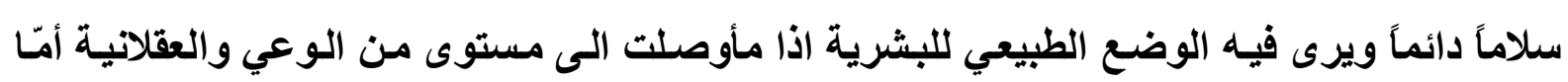

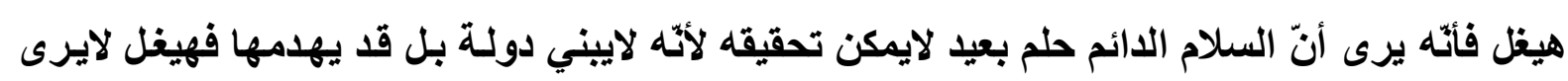

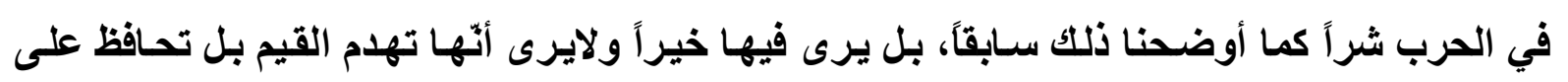


الصحة الأخلاقية للشعوب وبالتالي فانّ (كاتت) كان مختلفاً عن (هيخل) في مسالة شكل الدولة ونظام

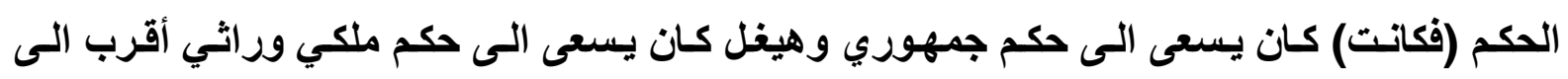

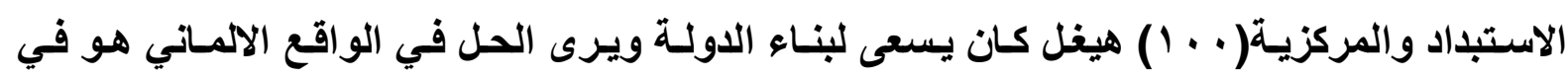

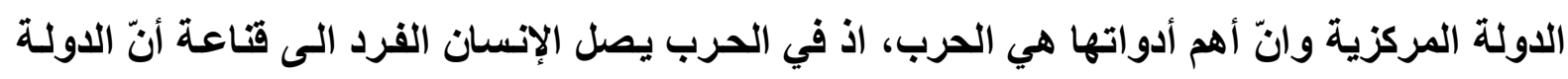

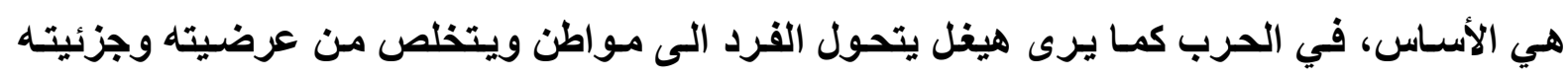
ويلتحق بالكلي والحرب هي أحد عوامل تقدم البثر وتقام وعيه.

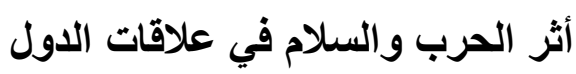

يرى هيغل أنّ الاساس في علاقة الدول مع بعضها هي الحرب وليس السلام فالدولة كمـا وصفها (هيغل) وأوضحنا ذلك سابقا هي كائن عضوي وهي فرد ولئ وليس تلجمعاً محضاً أو مجموعة أجزاء هي وحدة

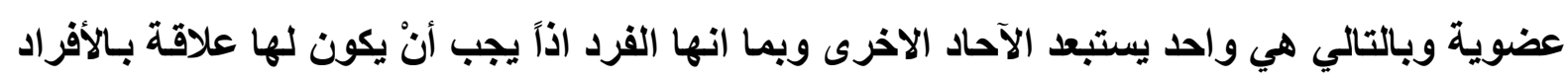

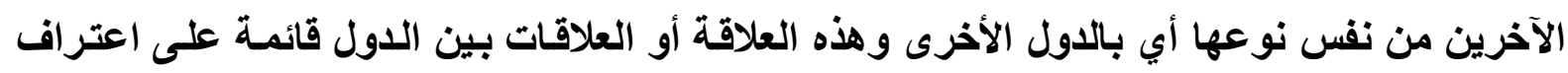

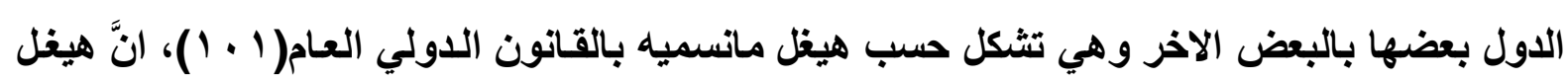

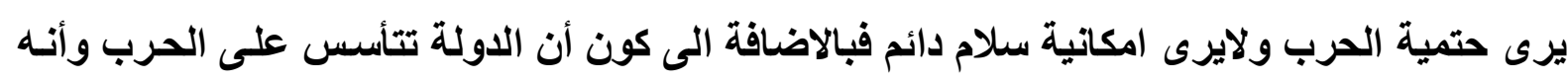

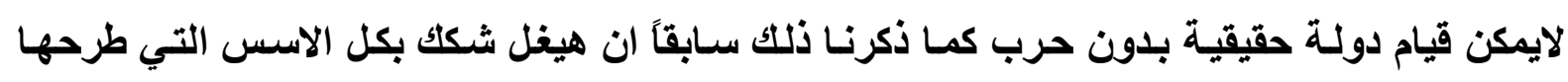

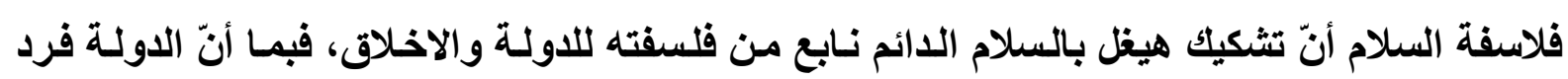

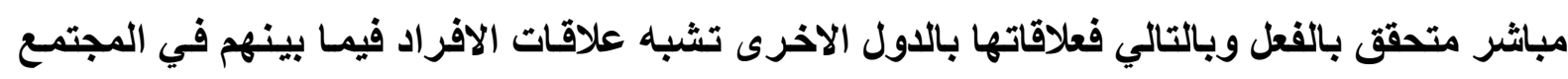

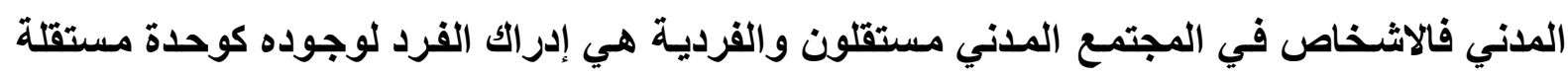

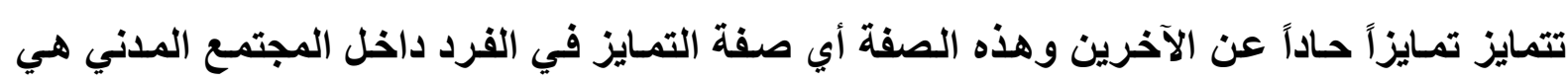

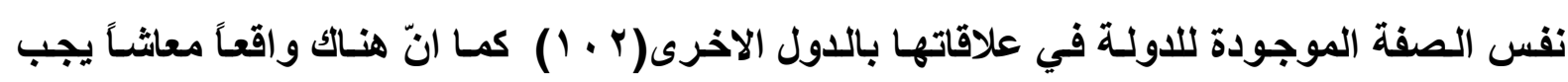

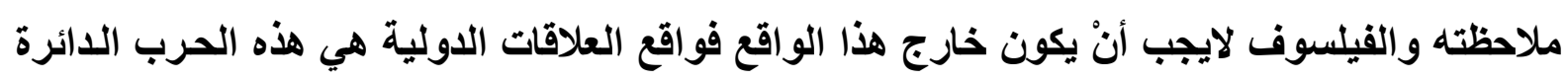

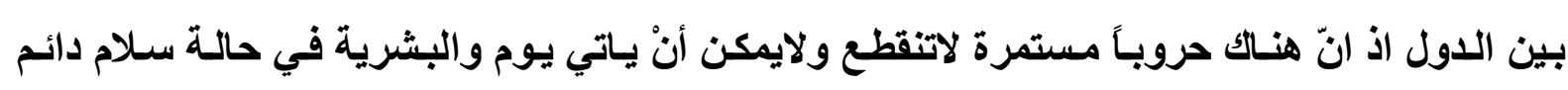

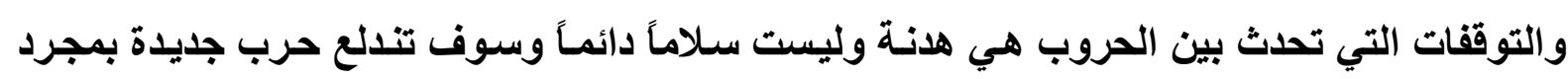

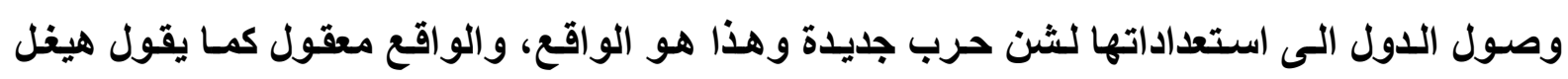

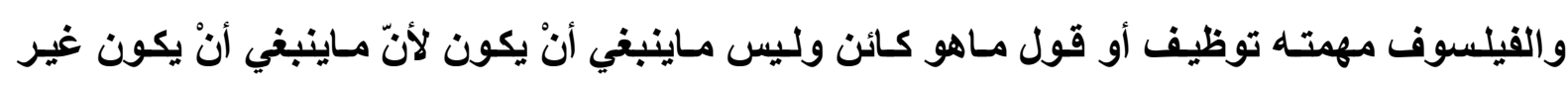

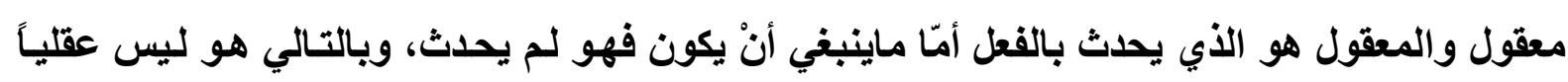

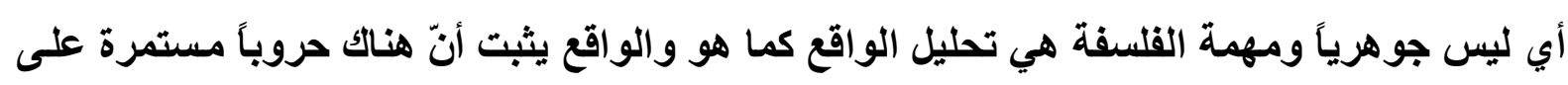
مرّز التاريخ مادامت هناك دول ومصالح متضاربة فيما بينها.

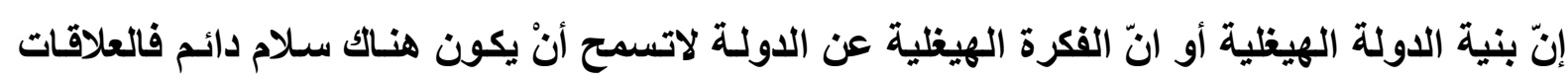

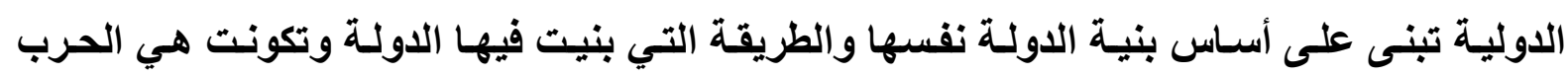


والصراع الداخلي الذي أنتج الدولة ينتقل الى الخارج الى علاقاتها الخارجية مع الدول الاخرى فالدولة

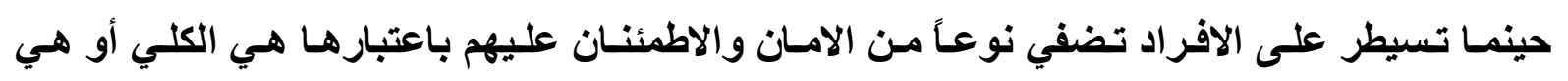

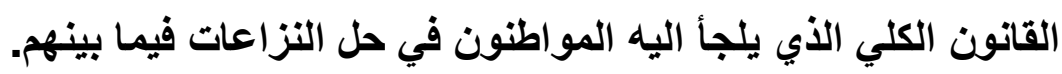

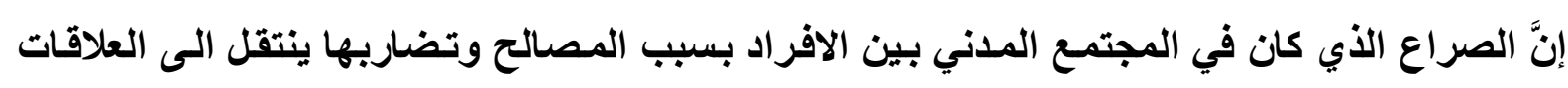

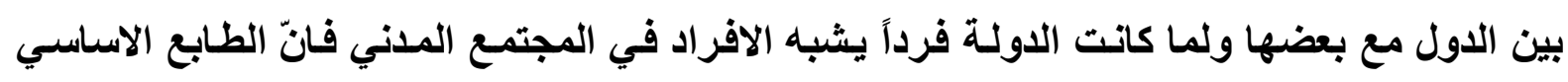

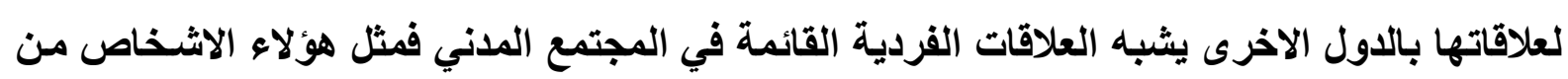

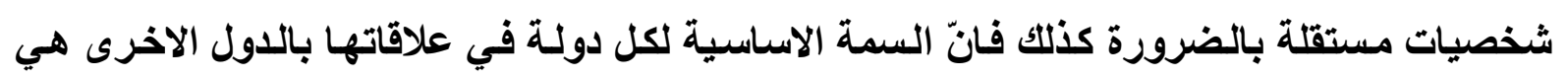

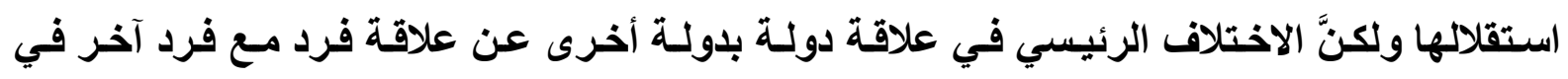

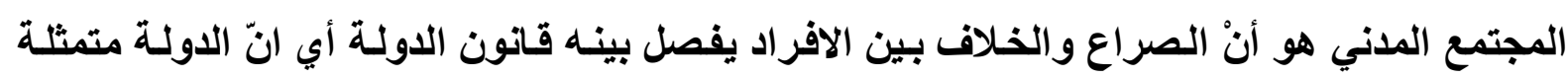

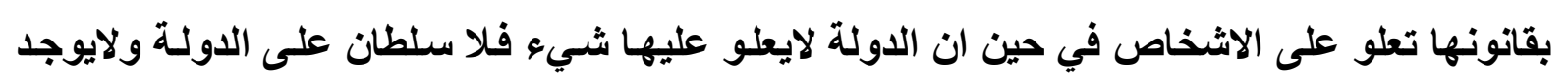

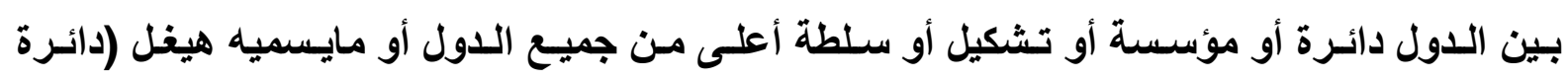

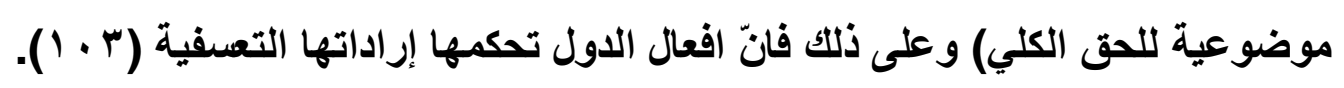

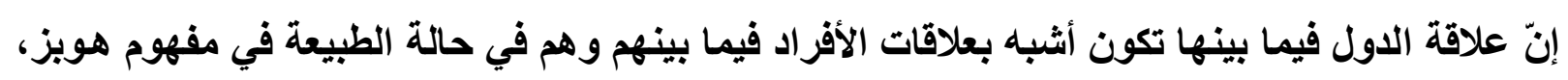

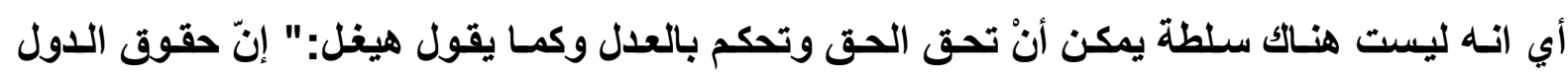

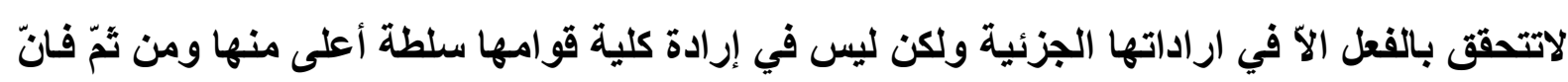

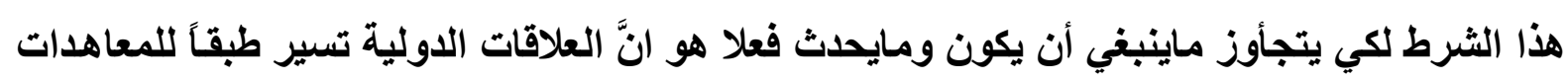

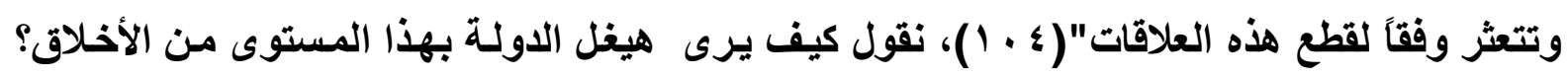

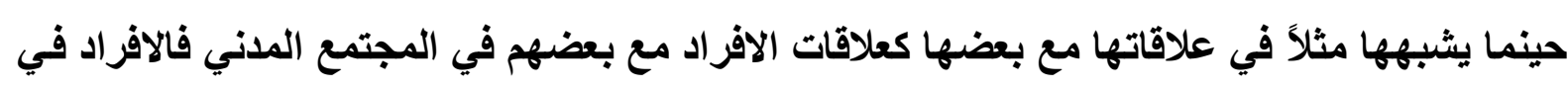

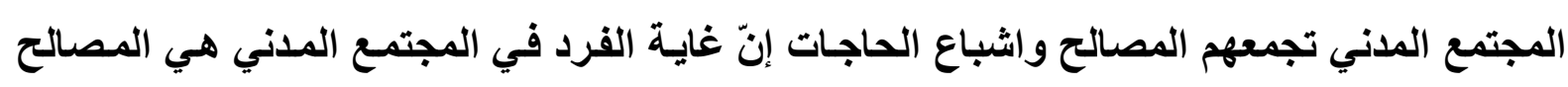

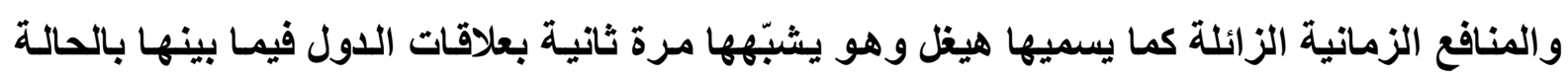

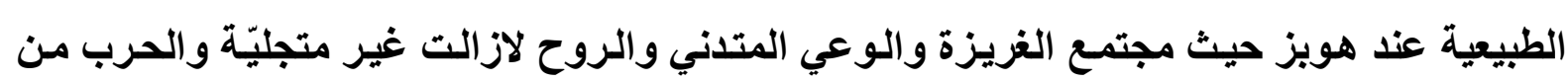

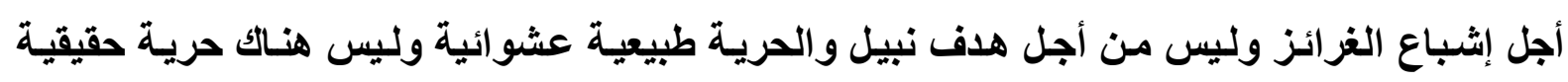

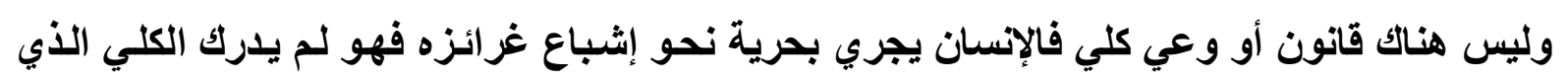

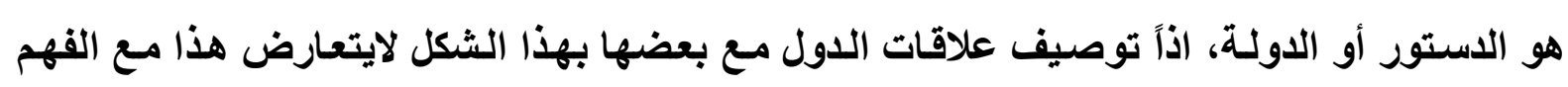

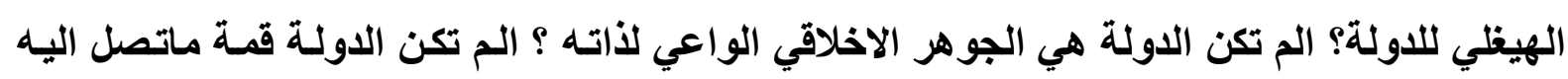

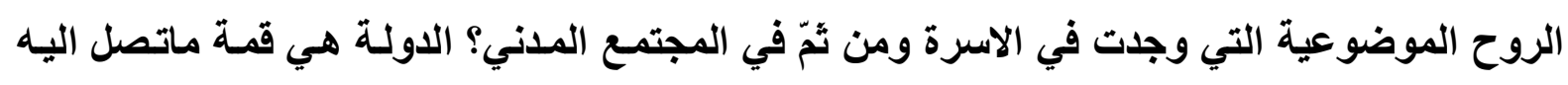

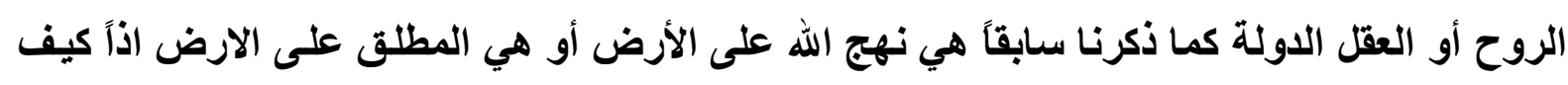

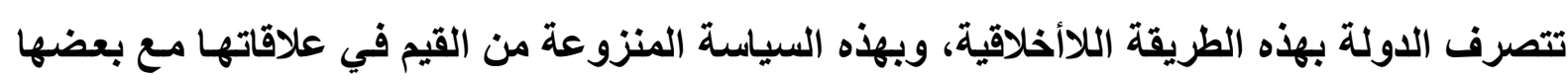

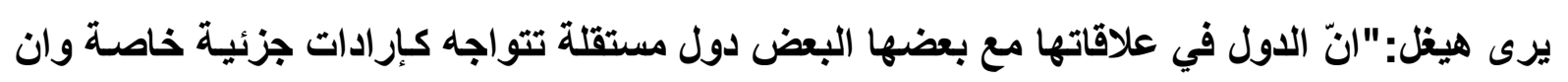


مصداق المعاهدات يقوم على هذا الأسـاس وإن الارادات الجزئيـة للكل خيرة ...ان هذا الخير هو القانون الأعلى الأي يحدد سلوك الدولـة في علاقاتها مـع الدول الاخرى وخصوصا ان صورة الدولـة هي انّ فيها التعارض بين الحق بوصفه حريـة مجردة وبين المضمون الذي يمثلها :الذي هو الخير - نقول: ان هذا التعارض يقضي عليه وان الاعتراف الأول بالاول يعد صالحاً بالنسبة اليها كلها من حيث هي كليّات عينية" (0 . 1)، لقد وضع هيغل صورتين للاولة مختلفتين عن بعضهما الصورة الأولى لاولة بمعناها المثالي أي الدولة التي صوزّ ها في مسيرة الروح والتي تجمع الأخلاق هيق والقيم النبيلة والتي تكون رمزاً للحق والخير والعدالة والحريـة والتي ينجذب اليها الفرد لائهـ يجد حريته فيها ويجد هدفه الأعلى النبيل ويدرك كليته (7 (1). والصورة الثاتية التي هي حقيقتها الفعلية شيء آخر اذ نجد هنـا أنّ جوهر الخير للاولة هو خيرهمـا الخـاص بوصفها فرديـة بين الفرديـات بـالمعنى الهيظلي ومصلحتها المعينة في موقف وفي ظروف خارجية معينة، بما في ذلك العلاقات الخاصة الناشئة عن المعاهدات فانّ الدولة هنـا لاترجع الى الفكر الكلي الاخلاقي التي بنيت عليه في علاقاتها مع الدول الاخرى والمرجع الذي ترجع اليه الدولة في الحروب والمعاهدات من منافع للاولة وليس هو القانون الاخلاقي العام أو الكلي وبالتالي فِإن الدولـة هنا كأي فرد في المجتمع المدني أو في حالة الطبيعة لاتلتفت الى المفـاهيم الكلية الاخلاقية بل الدولـة هنا تحارب من اجل مصالحها الخاصة أو منافعها لامن أجل قانون أخلاقي أي ليس من أجل مبدأ كليّ

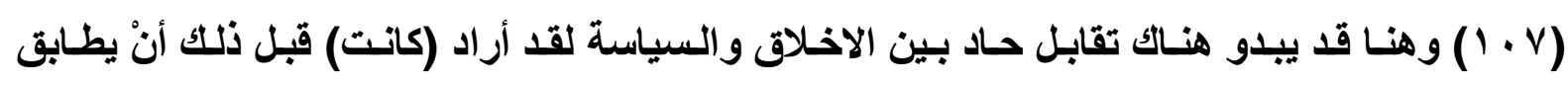
الأخلاق كقوانين عامة وعقلية بالسياسة كأمر واقع وأعتبر أنّ هذه العملية هي من آصعب العمليات أنْ تتوازى السياسة مع القيم الاخلاقية واعتبر ان القيم معرفية فمتى مايصل السياسي الى مرحلة من ون الوعي بحيث يدرك القانون الاخلاقي يستطيع رجل السياسة أن يعمل في الواقع وفقا للقانون الاخلاقي مئي

$$
\text { أي مجرداً من الهوى والعواطف والمنافع الشخصية (1 • (1). }
$$

في حين ان هيخل يرى أنّ الدولة يجب أنْ تتعامل بواقعية خاصـة مـ الدول الأخرى أي بمـا هو كائن وليس بما ينبخي أنْ يكون، اذ يرى أنّ خير الدولة ليس لهل معنى آخر غير الخيز الخـاص بفرد جزئي وانّ الجوهر الأخلاقي (الدولة) له وجود عيني مباشر وليس وجوداً مجرداً وهذا الوجود العيني ليس أي فكرة من الافكـار العامـة أي ليس قانونـاً اخلاقياً ذاتيـاً أو عامـا أي فكري مجرد أو قوانين اخلاقيـة عامة غير مطبقة على ارض الواقع بل في الحقيقة انّ هنـاك سلوك الدولـة وأفعالها الواقعية وحينمـا

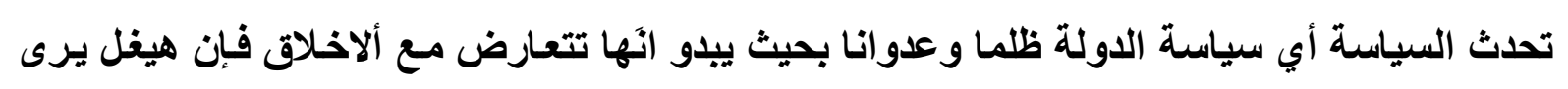

$$
\text { أنها طريقة، سطحية وضحلة في تصور الأخلاق (9 - (1). }
$$

إنَّ التبريرات الهيخلية للحرب، والمنفعة التي تتصف بها الدولة بعلاقاتها مع الدول الأخرى، واستغلال ضـف الدول المقابلـة في شـن حرب عليهـا في سبيل تحقيق منـافع جديدة ، يبدو فيهـا شـيء مسن 
الإسفاف، ودعوة الى الحرب غير مبررة رغم واقعيتها فليس هناك شيء أنبل، واحسن من الإنسان،

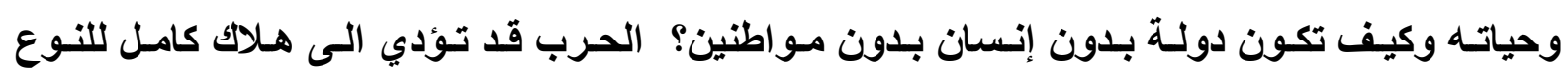

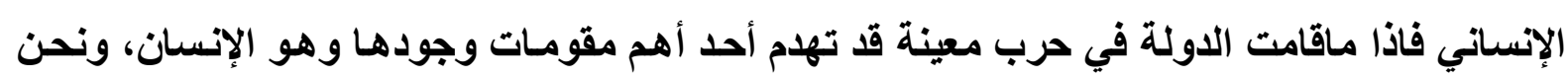

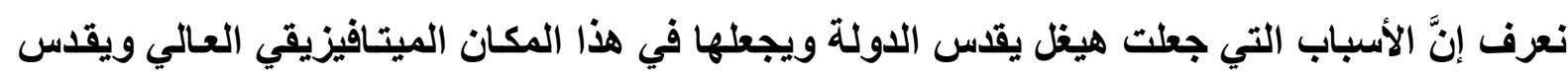

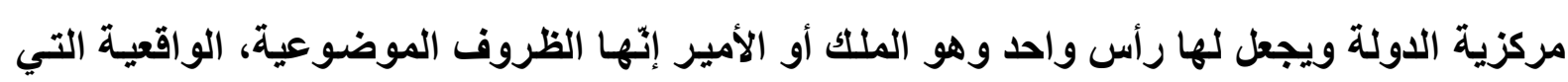

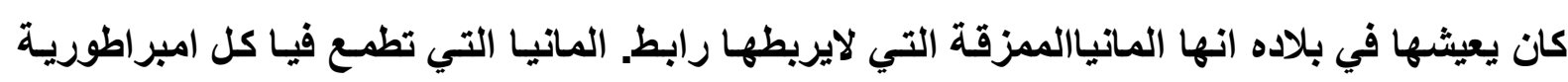

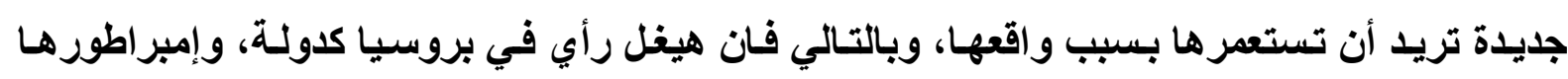

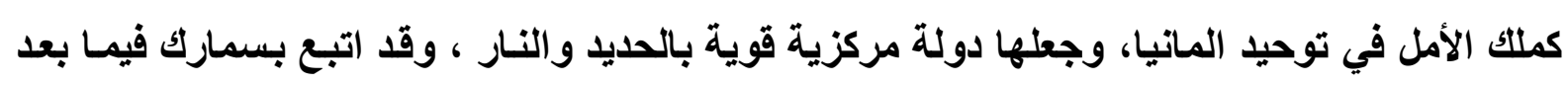

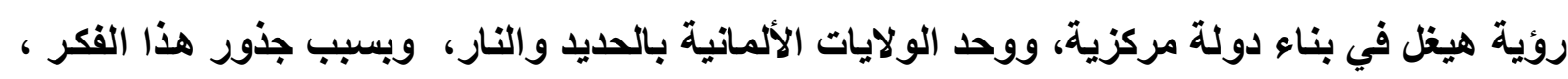

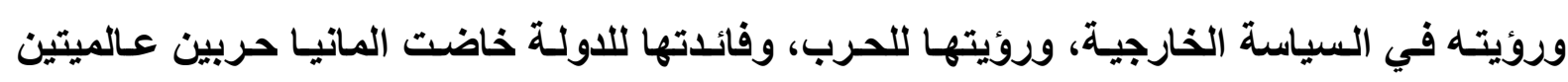

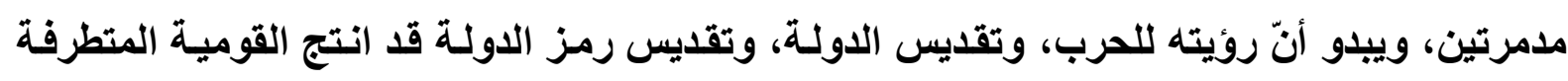

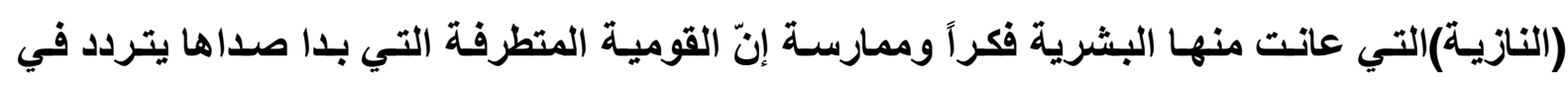
أصقاع الأرض، وبدات الكثير من الأحزاب، والمؤسسات، وأنظمـة الدول تستوحي أفكارهـا حتى في فئي

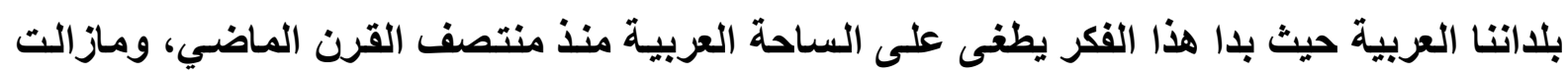

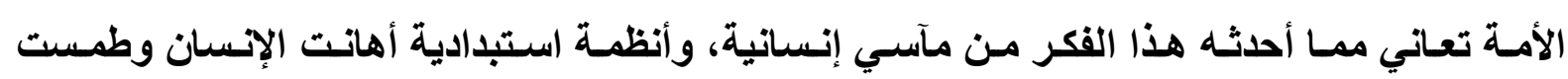

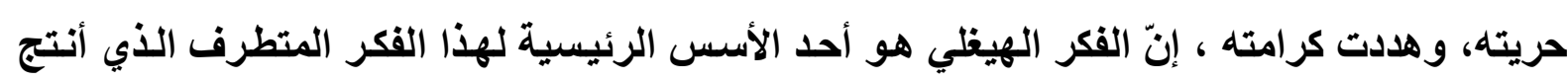

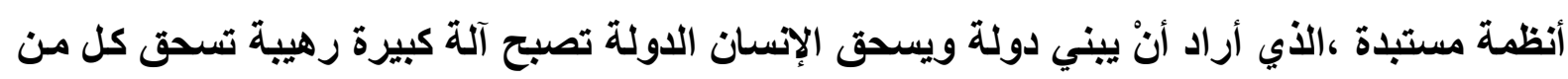

يقف أمامها .

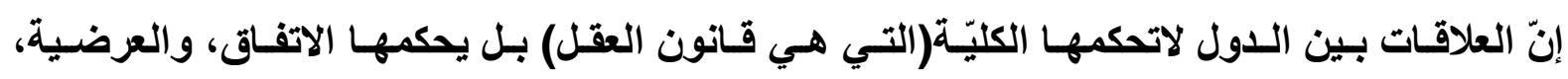

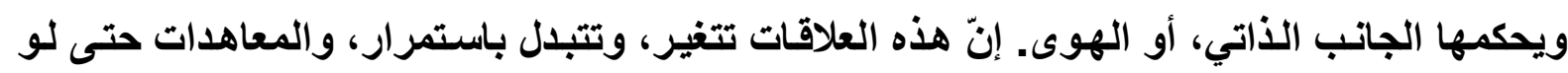

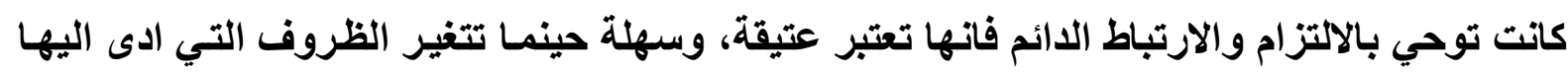

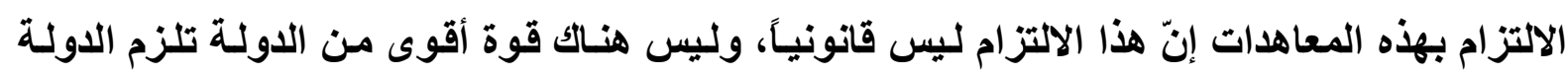

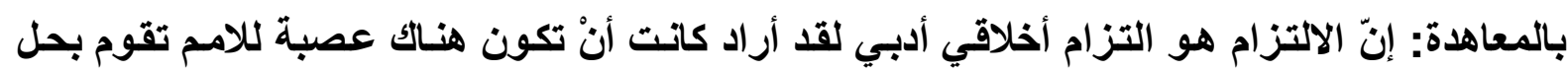

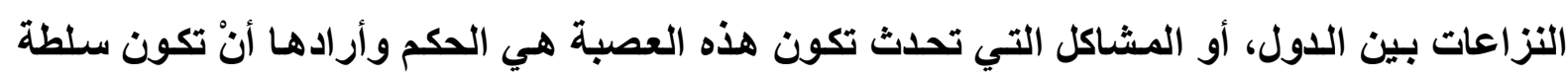
معترف بها من كل الدول وأنْ تكون هي الفيصل في كل النزاعات.

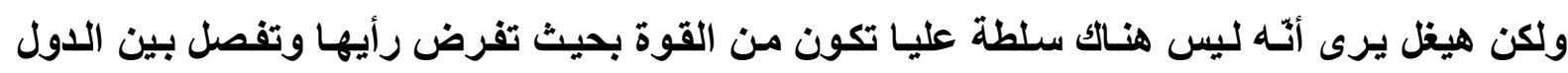

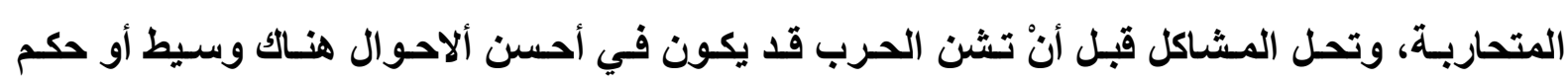

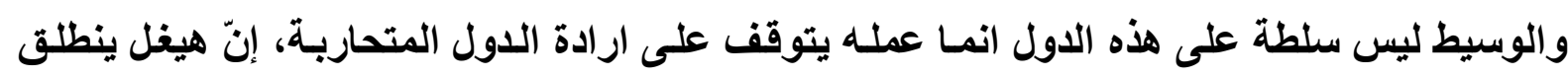
من موقف رفض السلام الدائم وحتمية الحرب من سبينين: 
الأول : يتعلق بمفهومه عن الدولة، وعلاقاتها مع الدول الأخرى وقد أوضحنا ذلك.

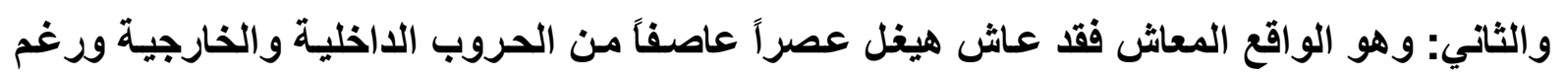

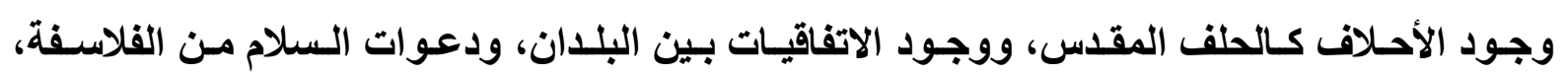

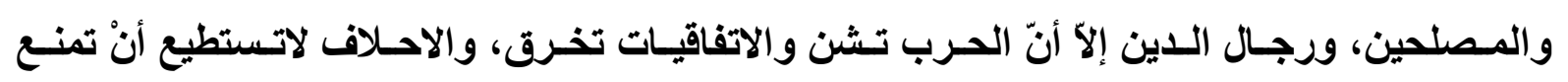

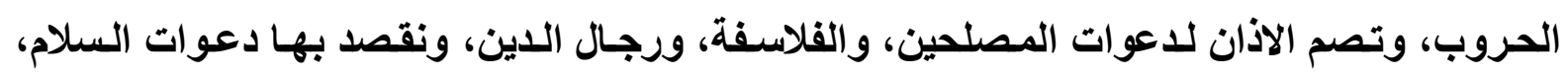
وهذا هو الواقع حروب مستمرة. يصنف هيغل الحروب بين الدول على نوعين فهناك حروب تكون انتهاكا محددا للمعاهدات ،وهنـاك

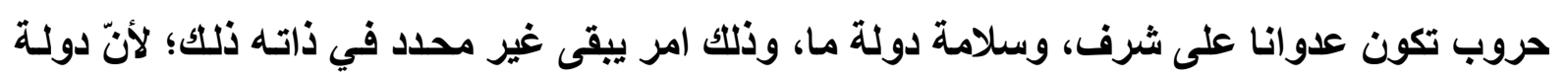

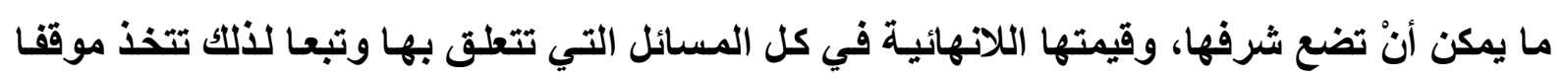

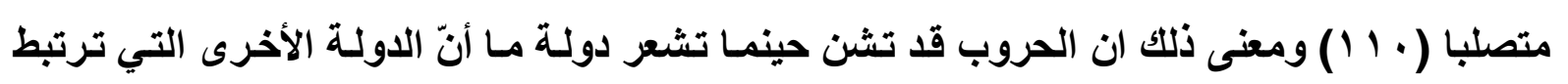

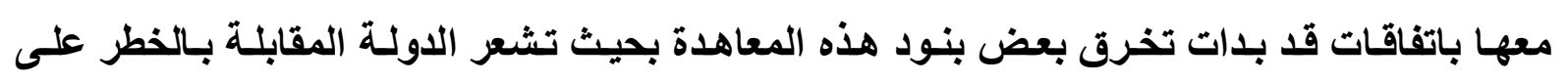

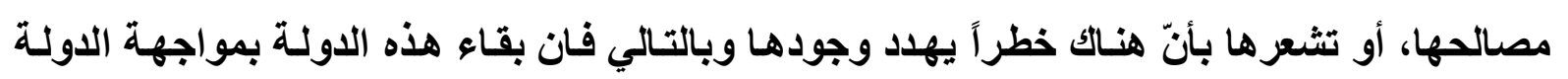

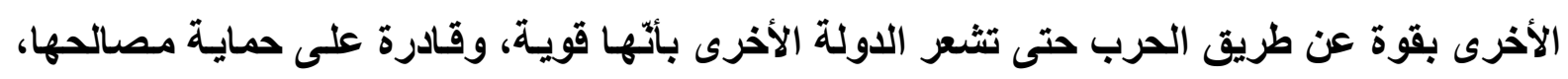

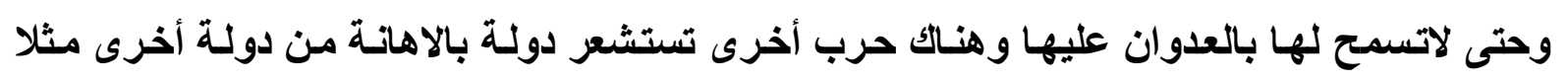

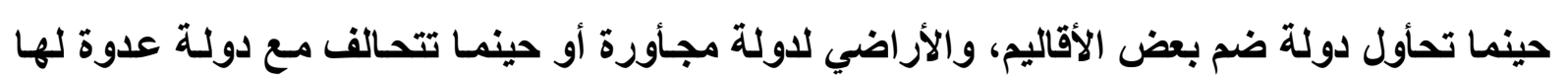

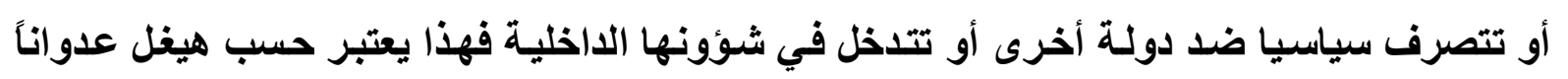

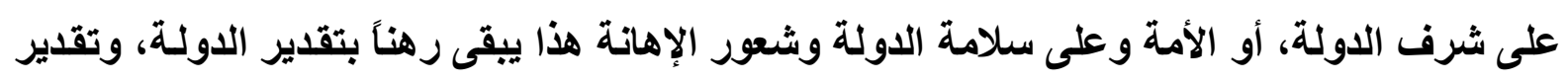

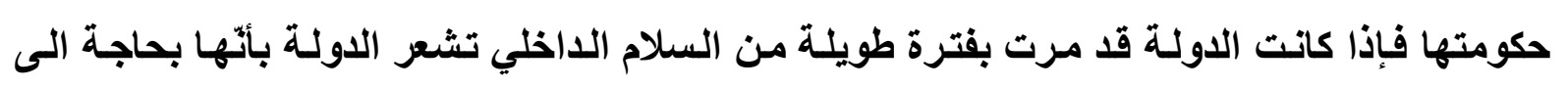

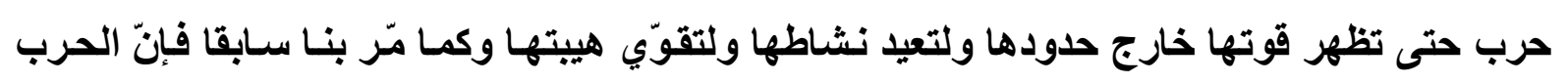

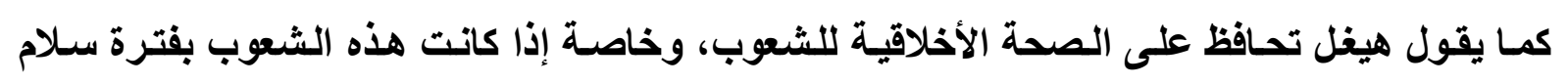

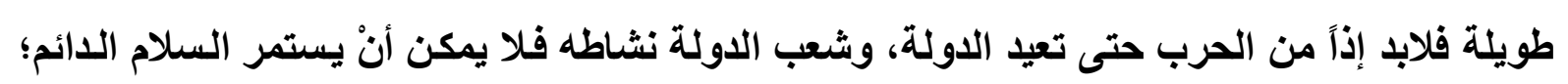

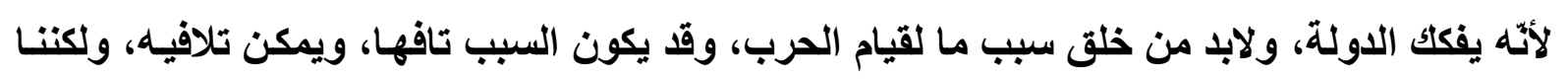

$$
\text { نجد الدولة تتخذ موقفا متصلب؛ لأثها هي تريد الحرب (111) }
$$

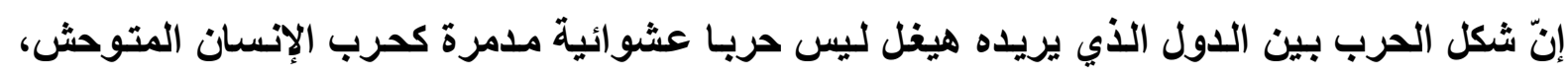

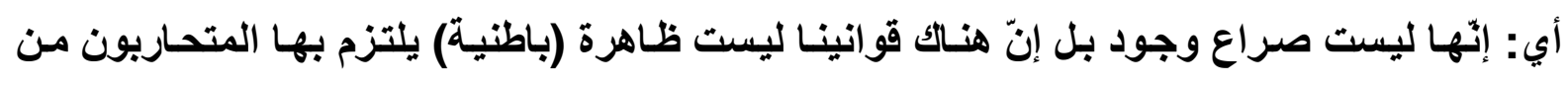

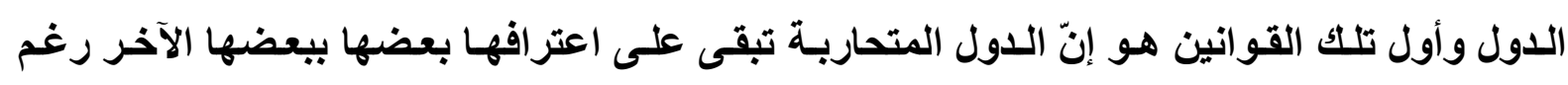

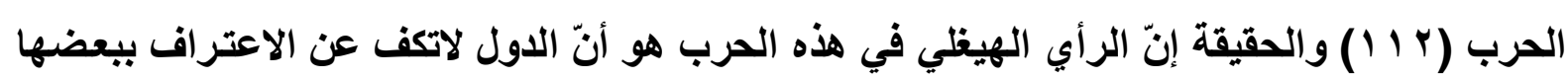

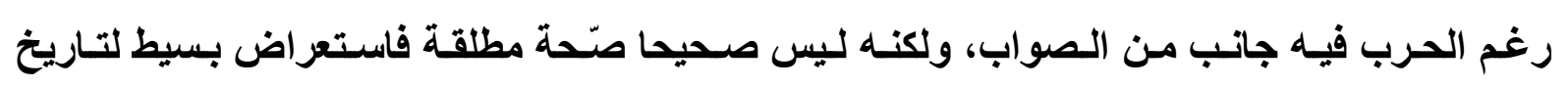


الحروب التي حدثت بين الدول في العالم على مر التاريخ نجد ان هناك حروباً قد قامت بين دول معينة

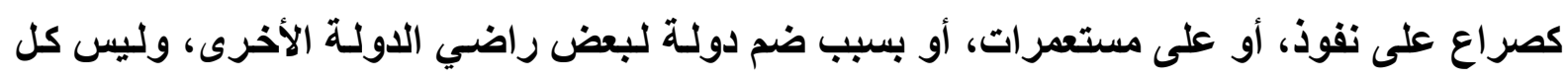

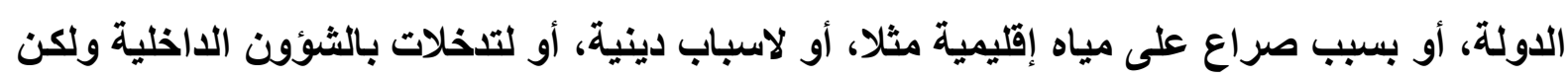

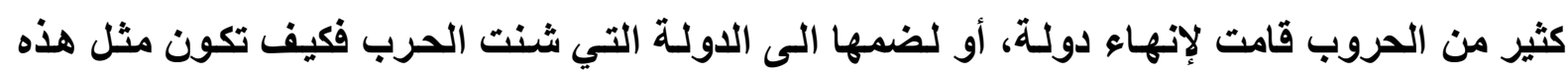

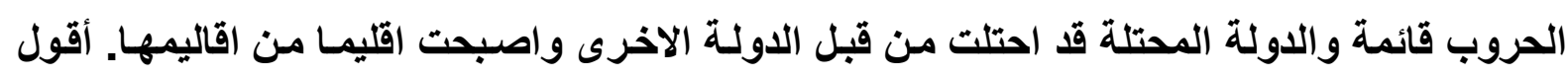

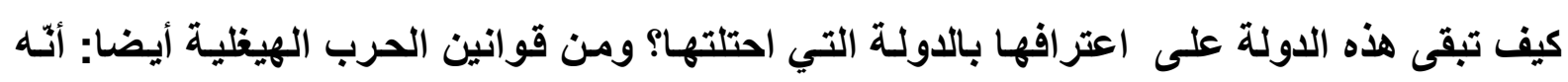

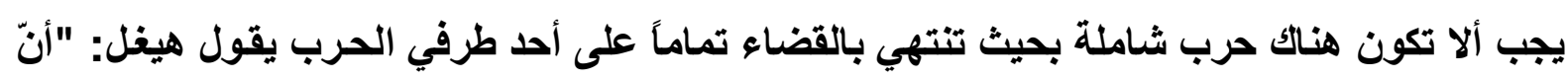

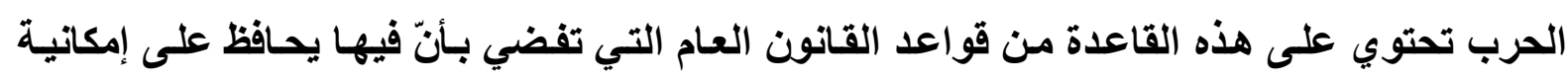

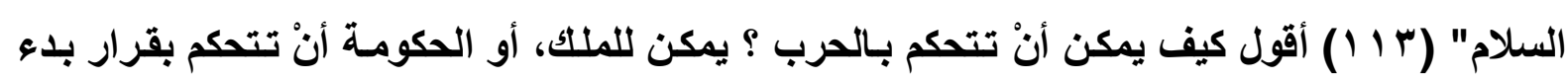

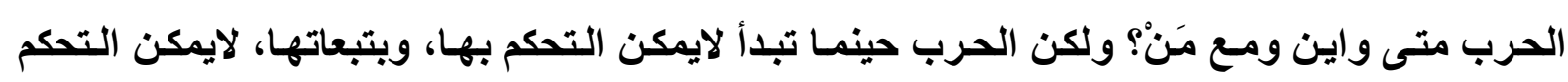

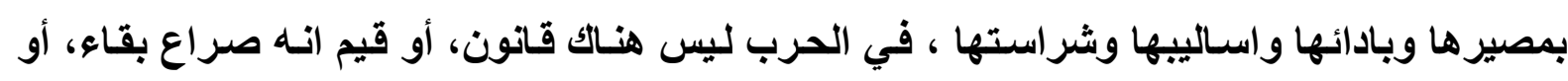

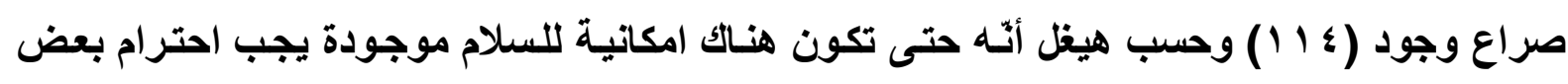

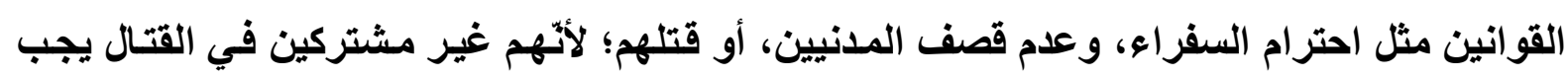

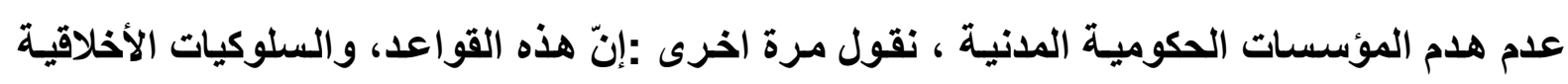
التي يرى هيغل أنّه يجب أنْ تراعى سوف لاتراعى، ولم تراع في أغلب الحروب، وحتى الحديثة منها

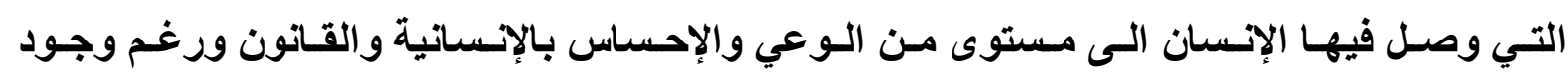

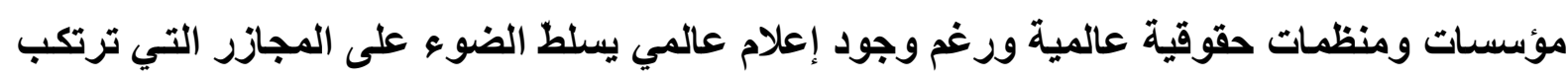

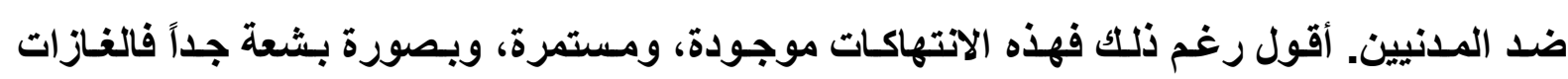

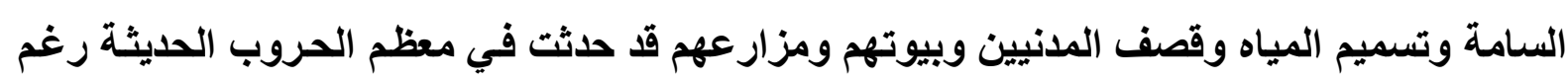

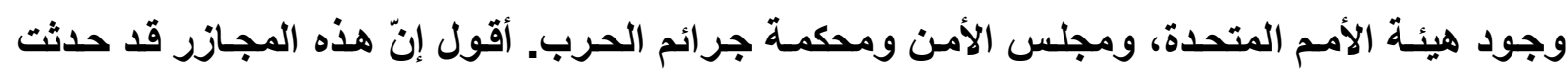

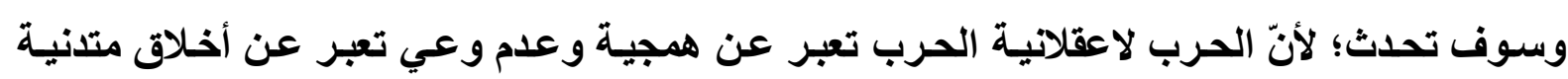

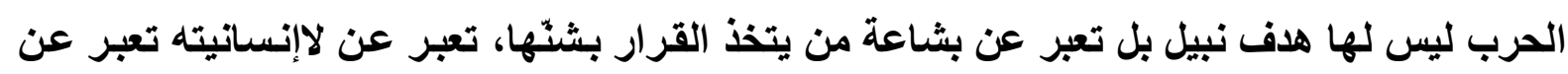
موت الضمير الإنساني الحرب بشعة في كل الأحوال وفي كل الأوقات. 
الكهوامش

ا . المحمدي ، د سيد علي : فلسفة كانت السياسية ، ترجمة عبد الرحمن العلوي ،طا ، دار الهادي ،

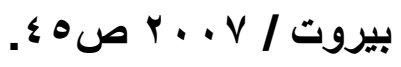

r. . سباين ، جورج : تاريخ الفكر السياسي الكتاب الأول ، ترجمة علي ابراهيم السيد ، مراجعة وتقديم

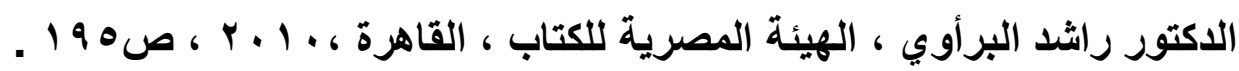
r. هيغل : محاضرات في فلسفة التاريخ (العالم الشرقي) ، ترجمة وتقديم وتعليق الدكتور إمـام عبد

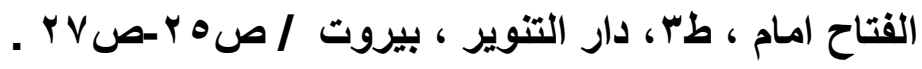

ع ـ د. سليمان ، عامر : الجيش والسلاح في العصر الآثوري موسوعة الجيش والسلاح ،ج1 ، بغداد . r rq-rrVu ، 1911

هـ خلف عبد الله ، يوسف : الجيش والسلاح في العها الاشوري الحديث ، طا ، بغداد ، سنة

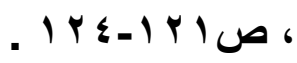

צ. محراث ، د. كاظم محمد : دراسات في الادب العربي القديم ، طا ، دار الضياء ، النجف الاشرف ،

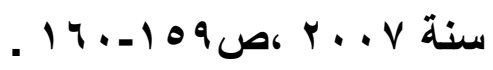

V. اندرو ، روبرت برن : تاريخ اليونان ، ترجمة محمد توفيق حسن ، مطبعة وزارة التعليم العالي ،

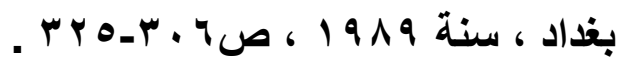

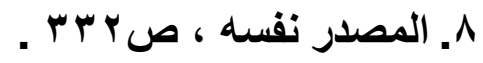

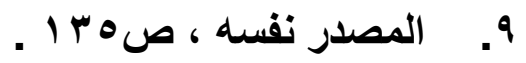




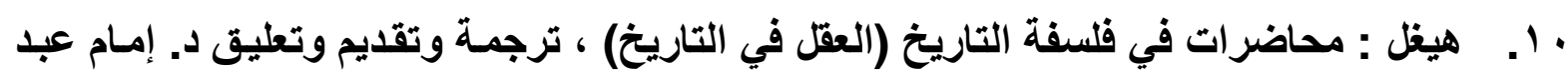

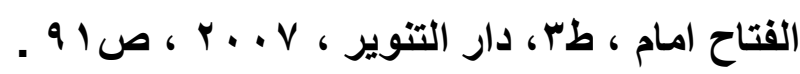

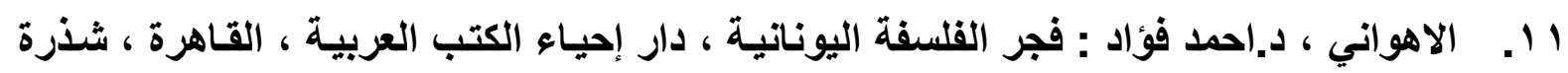

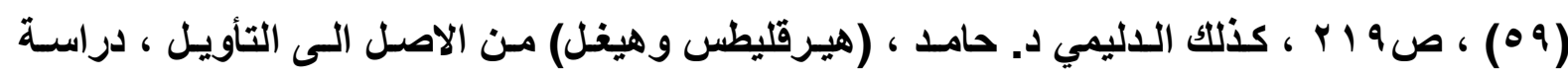

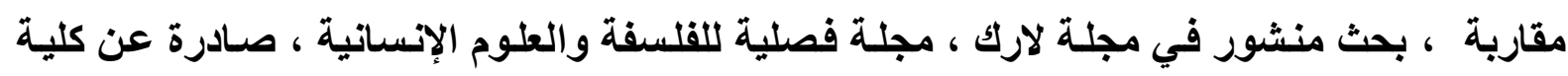

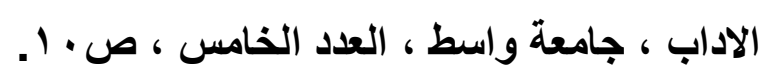

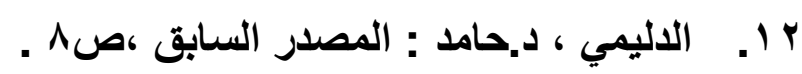

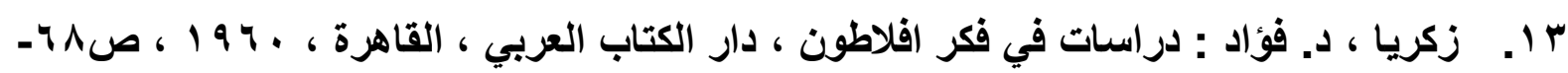
. v.

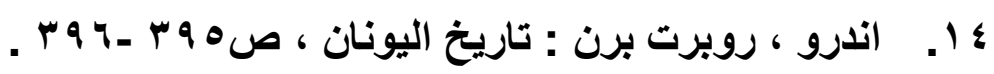

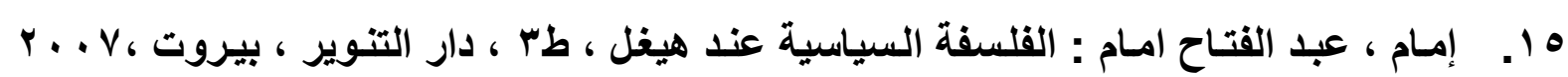
ك.

19

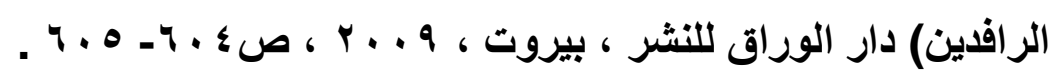

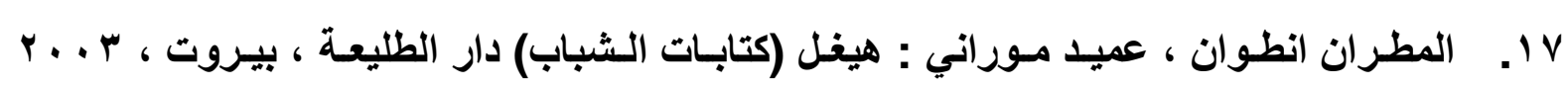
كو 9

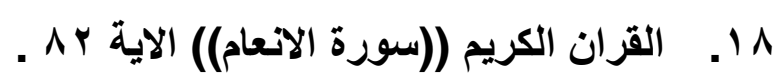
9 1. . ت اجر البندقية ، ويليم شكسبير على سبيل المثال (شخصية شايلوك) .

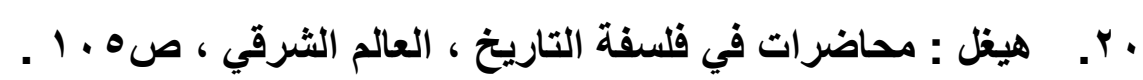

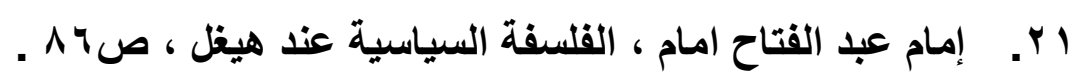

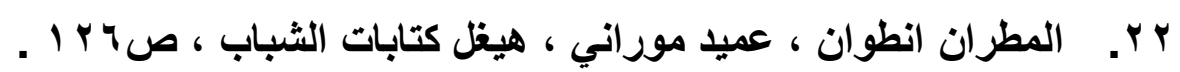

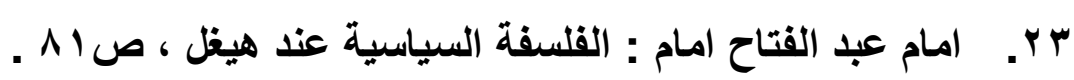

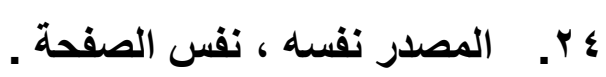

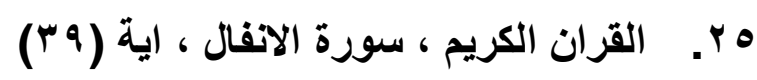

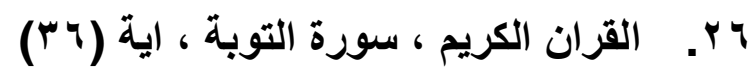

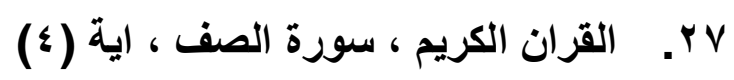

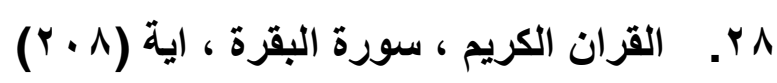

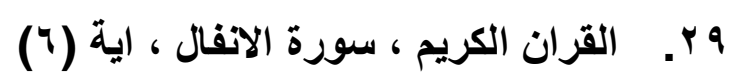

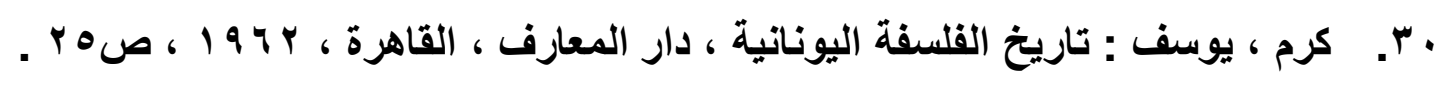




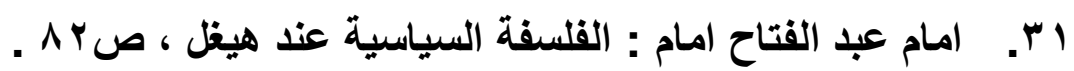

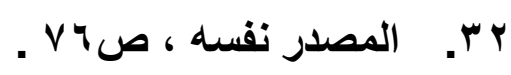
rr

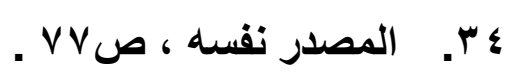

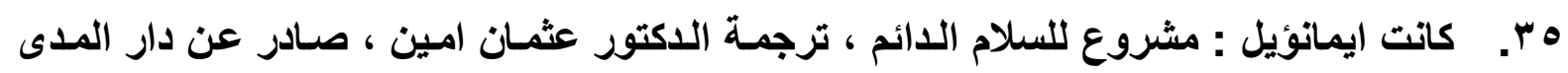

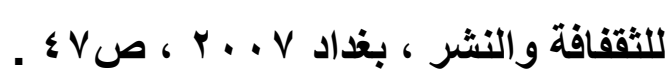

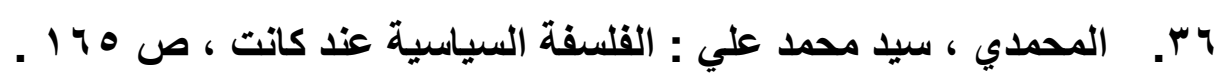
T rV

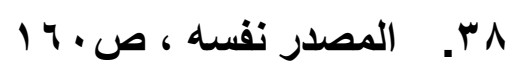

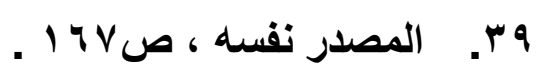

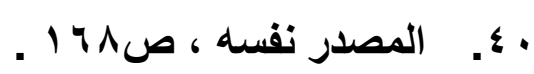

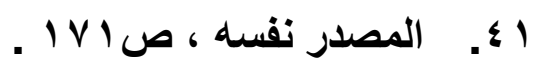

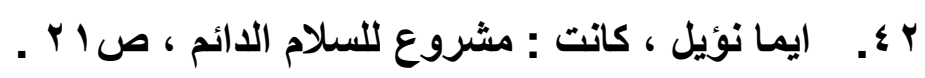

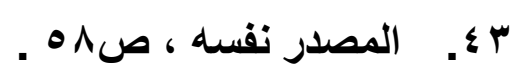

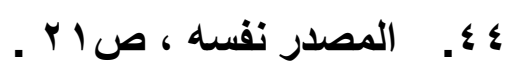

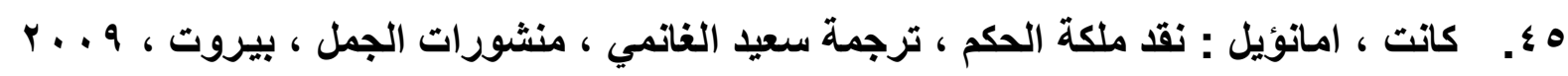
، صه.

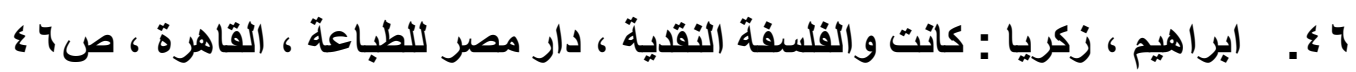

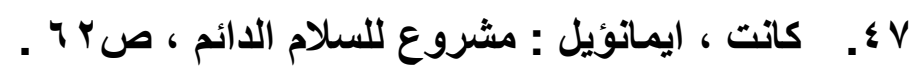

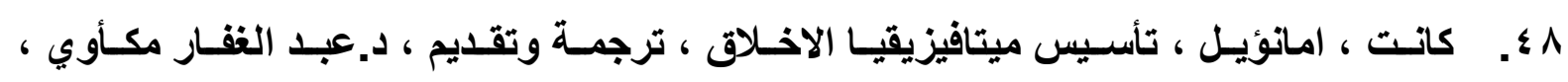

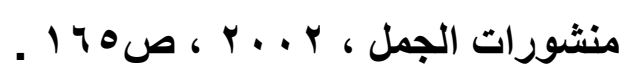

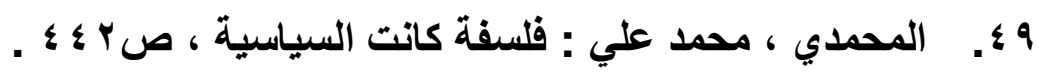
•.

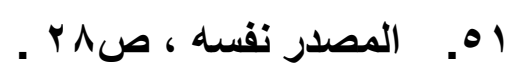

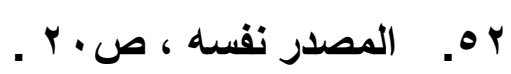

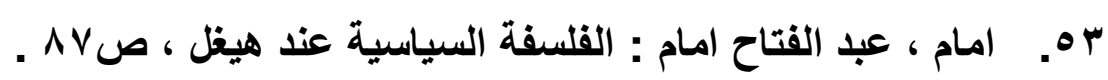

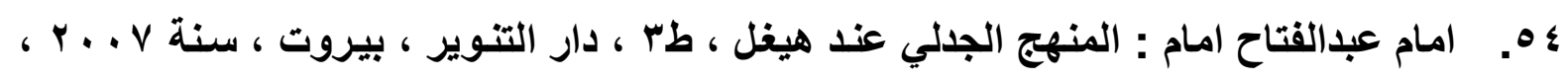
. IVI 
هـ. هيغل : مبادئ فلسفة الحق ، ترجمة تيسير شيخ الارض ، منشورات دار الثقافة ،بيروت ،

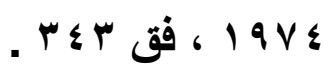

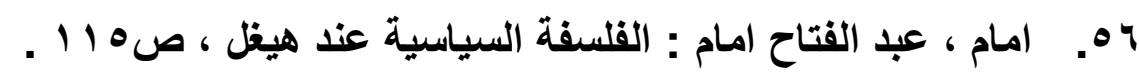

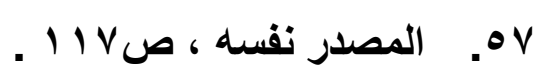

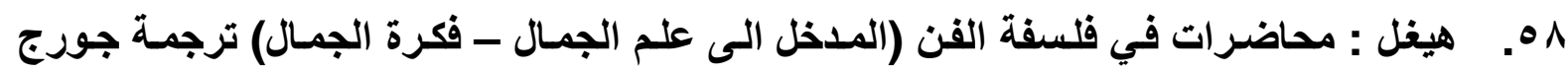

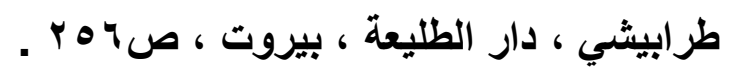
9ه. المصدر نفسه ، ص. ..r . . .7. المصدر نفسه ، صلا آ . וT. المصدر نفسه ، ص.rr.

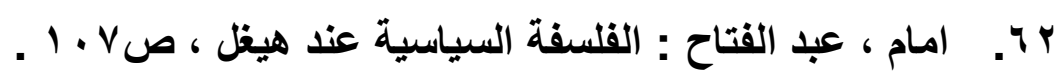

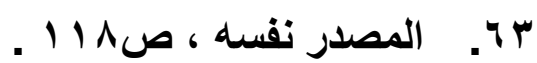
צ ج. بدوي ، عبد الرحمن : فلسفة القانون والسياسة عند هيغل: الطبعة الأولى ، دار الشروق ،

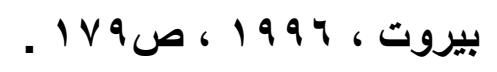
1.

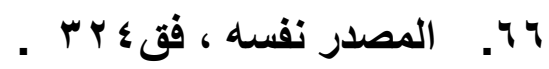

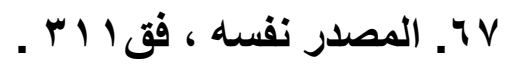
11. المصدر نفسه ، نفس الفقرة .

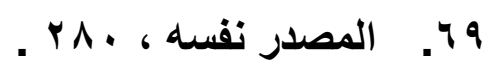

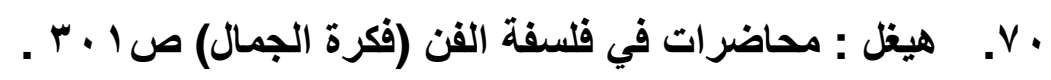

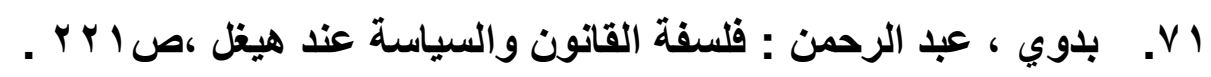
Tr r

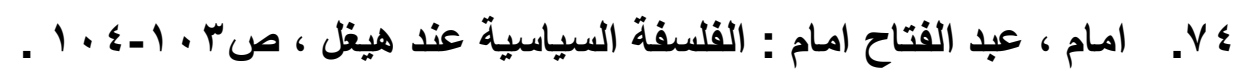

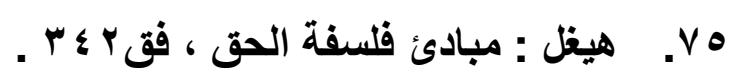
V Vy VV

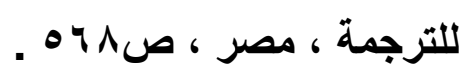

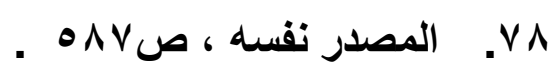


q. . هيغل : اصول فلسفة الحق ، ترجمة وتقديم وتعليق ، امام عبد الفتاح امسام ، طس ، دار التنوير

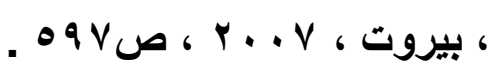

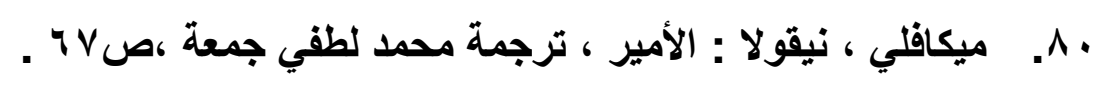

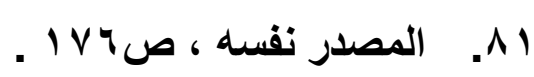

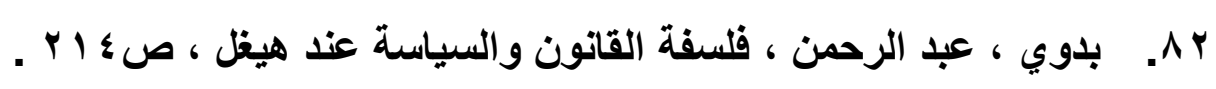
83. HEGEL:G.W.F. LE PHENOMENOLOGIE DE LESPRIT / TOM II TRADUIT PAR JEAN IT 4 PPOLITE/EDITIONS AUBIER/PANES (94)P.23.

84. Ibid . 24

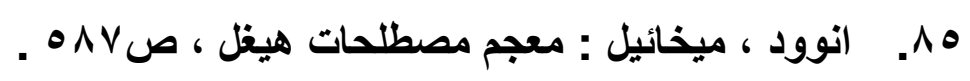

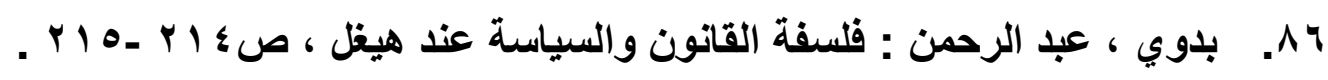

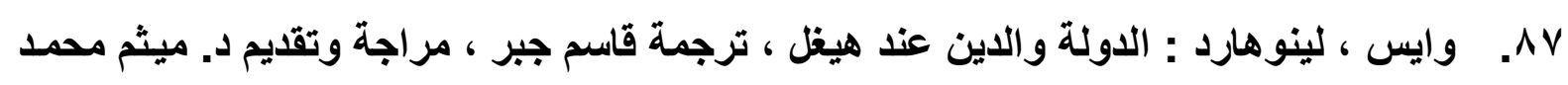

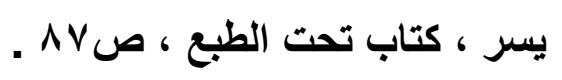
^^ـ. ستيس ، ولتر : فلسفة هيغل (فلسفة الروح) ترجمة وتعليق ، امسام عبد الفتـاح امسام ، دار

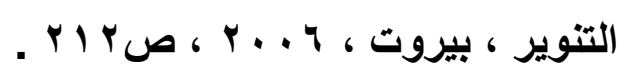
9. 9. • . . يسر ، ميثم محمد : الدين والدولة عند هيغل / اطروحة دكتور اه غير منشورة ، جامعة بغداد ،

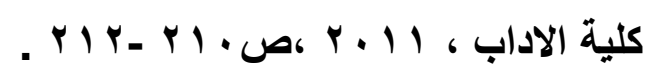

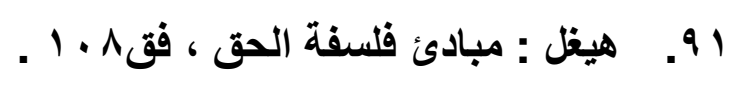

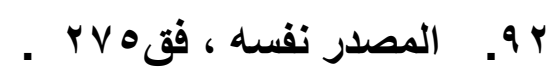

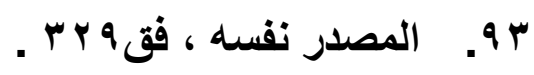

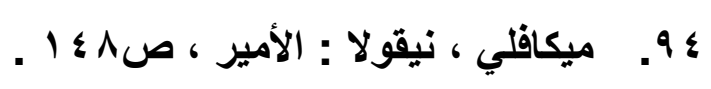

هو. سباين ، جورج : تطور الفكر السياسي (الكتاب الرابع) ترجمة علي ابراهيم السيد ، مراجعة

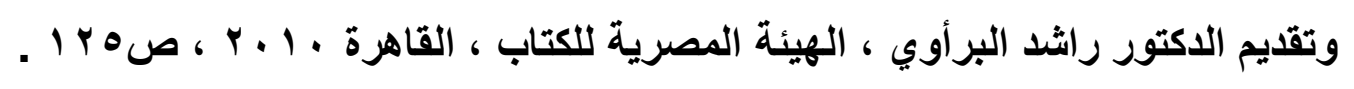

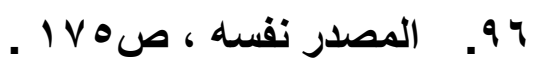

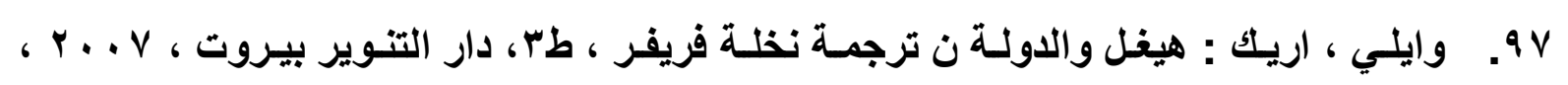
ص

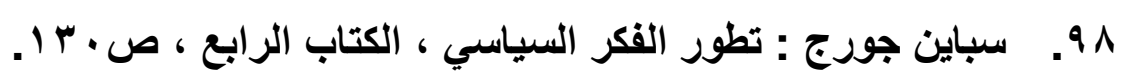

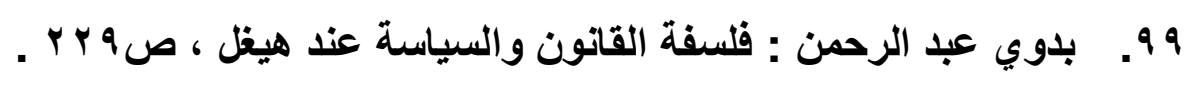




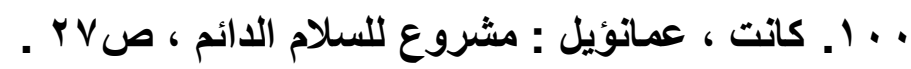

1 1. ستيس ، ولتر : فلسفة هيخل (فلسفة الروح) صا ب I . .

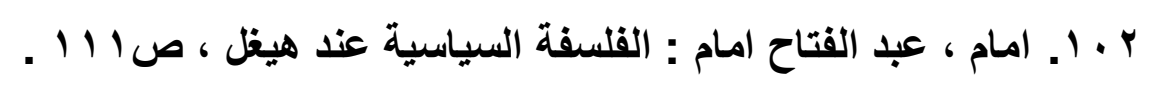

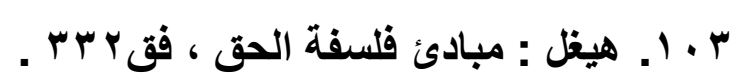

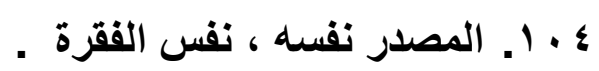

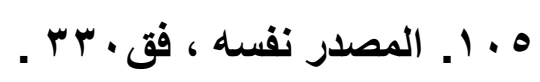

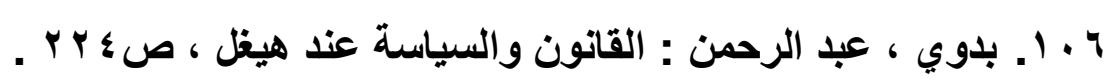

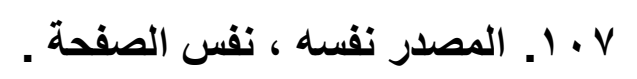

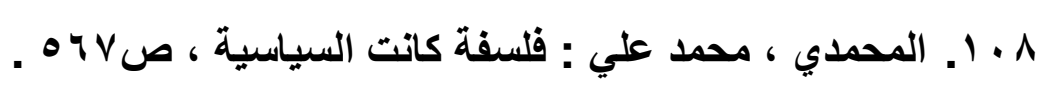

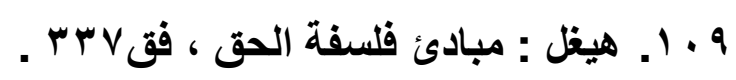

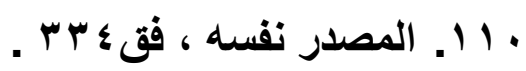

111 ـ بلدوي ، عبد الرحمن : فلسفة القانون والسياسة عند هيغل ، صبr بr . .

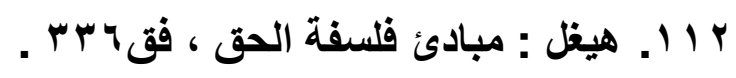

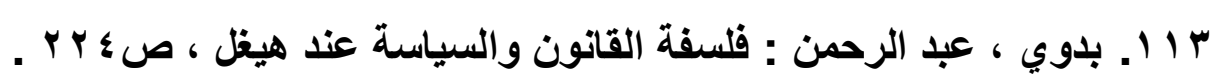

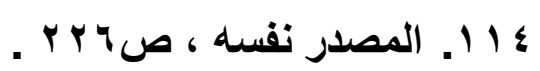

